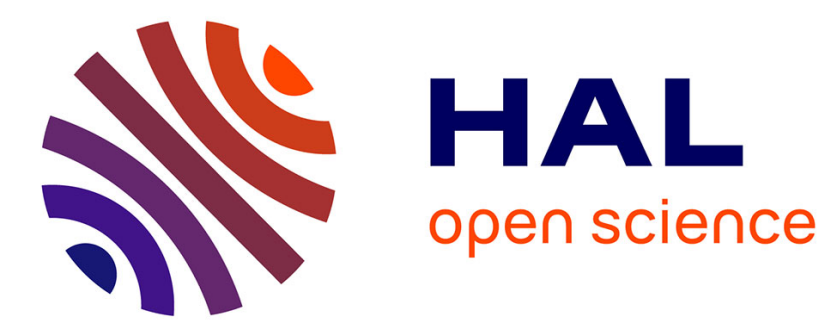

\title{
Risk in Islamic Banking
}

Pejman Abedifar, Philip Molyneux, Amine Tarazi

\section{- To cite this version:}

Pejman Abedifar, Philip Molyneux, Amine Tarazi. Risk in Islamic Banking. Review of Finance, 2013, 17 (6), pp.2035-2096. 10.2139/ssrn.1663406 . hal-01098717

\section{HAL Id: hal-01098717 https://hal.science/hal-01098717}

Submitted on 28 Dec 2014

HAL is a multi-disciplinary open access archive for the deposit and dissemination of scientific research documents, whether they are published or not. The documents may come from teaching and research institutions in France or abroad, or from public or private research centers.
L'archive ouverte pluridisciplinaire HAL, est destinée au dépôt et à la diffusion de documents scientifiques de niveau recherche, publiés ou non, émanant des établissements d'enseignement et de recherche français ou étrangers, des laboratoires publics ou privés. 


\title{
Risk in Islamic Banking ${ }^{1}$
}

\author{
Pejman Abedifar*, Philip Molyneux ${ }^{\dagger c}$, Amine Tarazi* \\ * Université de Limoges, LAPE, 5 rue Félix Eboué, 87031 Limoges, France \\ $\dagger$ Bangor Business School, Bangor University, Wales, LL57 2DG, UK
}

3 May 2012

\begin{abstract}
This paper investigates risk and stability features of Islamic banking using a sample of 553 banks from 24 countries between 1999 and 2009. Small Islamic banks that are leveraged or based in countries with predominantly Muslim populations have lower credit risk than conventional banks. In terms of insolvency risk, small Islamic banks also appear more stable. Moreover, we find little evidence that Islamic banks charge rents to their customers for offering Shariá compliant financial products. Our results also show that loan quality of Islamic banks is less responsive to domestic interest rates compared to conventional banks.
\end{abstract}

\section{JEL Classifications: G21; G32}

Keywords: Islamic banking, Islamic finance, bank risk, credit risk, stability, insolvency, Zscore, rent-seeking.

c Corresponding Author. Tel: +441248382170

E-mail addresses: pejman.abedifar@etu.unilim.fr, p.molyneux@bangor.ac.uk, amine.tarazi@ unilim.fr.

\footnotetext{
${ }^{1}$ An earlier version of this paper was circulated under the title "Risk and Stability in Islamic Banking". Thanks to Robert DeYoung, Thorsten Beck, Shahid Ebrahim, Franco Fiordelisi, John Goddard, Laetitia Lepetit, Steven Ongena, Philippe Rous, John Thornton, John Wilson and delegates at the European Central Bank's Workshop on Islamic Finance and Financial Stability, the International Workshop on Economic and Financial Risks Niort, IFABS Rome, FMA Denver Conferences and the Wolpertinger Valencia Seminar for constructive comments on earlier versions of the paper. All errors, of course, rest with the authors.
} 


\section{Introduction}

The world has observed various evolutionary stages in the field of banking and currently we see substantial growth in Islamic modes of banking and finance. According to TheCityUK (2011) the assets of Islamic banks (including the Islamic windows of conventional banks) increased to $\$ 1,041 \mathrm{bn}$ at the end of 2009 from $\$ 947 \mathrm{bn}$ in 2008 . This is expected to have grown by $10-15 \%$ during 2010 amounting to around $1.5 \%$ of global financial assets (Financial Times, 2011). The share of Muslims in the World's population ${ }^{2}$ also suggests greater potential for this type of financial activity in the future. Islamic banking has also experienced more rapid growth than conventional banking post-2008 crisis (Hasan and Dridi, 2010), has expanded outside the Muslim world to other continents including Europe and the Americas, and is continuing to develop a broad array of innovative solutions to meet Islamic financing demands (for instance, Shariá compliant credit default swaps). In line with these recent developments, the literature has grown rapidly, mirroring the growth of Islamic finance itself.

Islamic financial principles have evolved on the basis of Sharia law, which forbids payment or receipt of Riba - the payment or receipt of interest (Obaidullah, 2005). Financing principles are governed by Islamic rules on transactions "Figh Al-Muamelat" and follow both Profit and Loss Sharing (PLS) and non-PLS arrangements (such as leasing contracts). In addition to the prohibitions on interest, Islamic banks also face other restrictions - such as the use of many derivatives products, because according to Shariá all contracts should be free from excessive uncertainty "Gharar" (Obaidullah, 2005) .

\footnotetext{
${ }^{2}$ Muslims represent around 23\% of the world population as reported by Pew Research Center (2009).

${ }^{3}$ Islamic derivative products that are permissible include: spot commodity and money transactions (where exchange takes place contemporaneously or is deferred - the commodity is delivered at $t+0$ and the money delivered at $t+1)$, and Salam contracts (where money is paid at $t+0$ and the commodity delivered at $t+1$ ). There is widespread debate as to whether Futures transactions (where money and commodity payments / deliverables are deferred) are Islamic.
} 
Several papers have outlined the specific risks inherent in Islamic banking. Errico and Farahbakhsh (1998) for instance point out that prudential supervision and regulations governing Islamic banks should place a greater emphasis on operational risk and information disclosure. They explain the special risks attached to PLS. For instance, in certain cases Islamic banks cannot mitigate credit risk by demanding collateral from clients, as their relationship is established on the basis of partnership; moreover, they do not have enough control over the management of projects financed in the form of Mudarabah. Khan and Ahmad (2001) claim that sharing Islamic banks' profit or loss with their investment account holders introduces withdrawal risk. They also argue that different Islamic modes of finance have their own unique risk characteristics due to the various constraints enforced by Shariá (Islamic rules). Sundararajan and Errico (2002) suggest that the complexities of PLS modes of finance and the risks associated with the non-PLS activities should be taken into account to establish more effective risk management. They also point out various moral hazard issues that occur as a result of the special relationship between Islamic banks and investment account holders. Obaidullah (2005) argues that (deposit) withdrawal risk may persuade Islamic banks to deviate from traditional Shariá financing principles. This occurs if banks pay competitive market returns to investment account holders regardless of the bank's actual performance.

Table I provides a summary of empirical literature on Islamic banking where some of the aforementioned issues are analyzed. Early empirical work focuses on the efficiency and production technology features of banks (El-Gamal and Inanoglu, 2002; Yudistra, 2004) whereas more recent studies examine competition (Chong and Liu, 2009; Weill 2011), asset quality (Beck et al, 2010), stability (Čihák and Hesse 2010) and other risk dimensions including loan default rates (Baele et al, 2010). Apart from some notable exceptions, the empirical literature suggests no 
significant differences between Islamic and conventional banks in terms of their efficiency, competition and risk attributes.

\section{[TABLE I]}

An interesting and related dimension focuses on the disciplinary role of depositors and whether this is influenced by the religiosity of Islamic bank customers. Banking theory (Diamond and Rajan, 2000 and 2001) points out that the discipline imposed by depositors mitigates risky bank lending. In the context of Islamic banking the PLS relationship between the bank and investment account holders, however, appears less clear-cut than in conventional banking. Previous literature (such as Miller and Hoffmann, 1995 and Osoba, 2003) claims that religious people are more risk averse so Islamic bank depositors may be more sensitive to bank performance and demonstrate greater withdrawal risk than those at conventional banks. Alternatively, they may show loyalty (for religious reasons) towards their bank and thus mitigate the discipline exerted by withdrawal risks. In addition, Islamic bank clients may also be prepared to pay rents for receiving financial services compatible with their religious beliefs.

This paper contributes to the most recent literature by investigating bank credit and insolvency risk $^{4}$ for a sample of Islamic banks, conventional banks with Islamic windows (hereafter referred to as Islamic window banks) and traditional commercial banks from 24 member countries of OIC over 1999 to 2009 . We also explore whether Islamic banks exploit the religiosity of their customers by extracting rents (higher loan or lower deposit rates) for offering Shariá compliant products and services.

\footnotetext{
${ }^{4}$ In this paper, we are interested in bank risk at the individual level, rather than systemic risk. Typically, the countries where our sample of Islamic and non-Islamic banks are based did not experience the credit crisis of 2008 onwards. These economies are also less leveraged than Western systems. For example, according to the World Bank web-site, in the U.S. domestic credit provided by the banking sector is estimated at around $219 \%$ of GDP between 1999 and 2009, compared with about 50\% for the countries under study in this paper.
} 
Overall we find that Islamic banks have lower credit risk than conventional banks, specifically small, leveraged or those operating in countries with more than $90 \%$ Muslim populations. In terms of insolvency risk small Islamic banks are more stable than small conventional banks, as they are more capitalized; however, no significant difference between large Islamic and conventional banks is observed. Loan quality, (implicit) interest income and expense of Islamic banks are less sensitive to domestic interest rates compared to their conventional counterparts; however, the sensitivity of Islamic banks' stability to interest rates is not significantly different from conventional banks. Finally, we find no evidence that Islamic banks charge rents to their clients for offering Shariá compliant financial products. The paper is organized as follows. Section 1 discusses the key features of Islamic finance and risk issues and Section 2 outlines our methodology. Section 3 describes the data and Section 4 presents the results. Finally, section 5 concludes.

\section{Background on Islamic Banking}

This section briefly explains the key features of Islamic finance and its possible impact on the risk and stability of banks.

\subsection{FEATURES OF ISLAMIC FINANCE}

Islamic finance is based on Shariá principles which forbid payment or receipt of Riba $a^{5}$. Riba refers to an excess to be returned on money lending. The Islamic terminology for such a kind of lending is "Qard Al-Hasan". It is interesting to note that Shariá recognizes the time value of money, since according to Islamic rules the price of a good to be sold on a deferred payment

\footnotetext{
${ }^{5}$ There are two types of Riba: Riba in debt and Riba in exchange. For more details see Obaidullah (2005). This paper focuses only on Riba in debt.
} 
basis can be different from its current value. Interest reflects the time value of money and the interest rate is an exchange rate across time. While Shariá recognizes interest in business it prohibits interest on lending (Obaidullah, 2005).

Islamic finance has evolved on the basis of Islamic rules on transactions, Figh alMuamalat, and can mainly be categorized as: 1) Debt-based financing: the financier purchases or has the underlying assets constructed or purchased and then this is sold to the client. The sale would be on a deferred-payment basis with one or several installments. 2) Lease-based financing: the financier purchases or has the underlying assets constructed or purchased and then rents it to the client. At the end of the rental period (or proportionate to the rentals) ownership would be transferred wholly or partially to the client. 3) PLS financing: the financier is the partner of the client and the realized profit or loss would be shared according to pre-agreed proportions (Khan and Ahmed, 2001). The first two Islamic finance methods are collectively known as Non-Profit and Loss Sharing "Non-PLS". Besides restrictions on Riba, Shariá has various other prohibitions which should be taken into account. For instance, according to the Shariá all contracts should be free from excessive uncertainty "Gharar" (Obaidullah, 2005); hence as noted earlier, Islamic financial institutions face some restrictions on application of financial derivatives and other types of contracts (including various forms of insurance policies).

\subsection{ARE ISLAMIC BANKS RISKIER THAN CONVENTIONAL BANKS?}

In this section, the asset and liabilities structure of Islamic banks are analyzed highlighting their specific risk features. 


\subsubsection{Liabilities}

Islamic banks are authorized to receive deposits mainly in the following two forms (Iqbal, et al., 1998): current accounts ${ }^{6}$ that bear no interest but are obliged to pay principal to holders on demand, and investment (or savings) accounts that generate a return based on profit rates. Such rates may be adjusted according to the realized profit or even loss which would then be shared between the Islamic bank and the investment account holders. This PLS arrangement can (in theory at least) provide pro-cyclical protection to banks in the event of adverse conditions - profit rates decline in bad times and increase in good times. The extent to which investment deposits are important as a source of funding, therefore, can have an impact on the asset portfolio of Islamic banks.

Due to the obligations towards depositors as debt-holders, conventional banks aim to allocate a part of their funds to liquid assets, and endeavor to decrease the volatility and uncertainty of loan revenues so as to meet depositor obligations. Islamic banks, however, have more flexibility, since they can consider investment depositors more like equity holders. However, this flexibility may be mitigated by the fact that Islamic banks have limited access to wholesale funding. There is a fledgling Islamic money market (noticeably in Bahrain and Malaysia) although only the largest institutions have access. As such, Islamic banks are rather constrained from engaging in active liability management like conventional banks.

Calomiris and Kahn (1991) and Jeanne (2000) argue that short-term debt is useful in disciplining financial intermediaries. Diamond and Rajan $(2000,2001)$ also show that the issue of demand deposits encourages banks to monitor their lending activities. They also claim that a bank run is the Nash equilibrium for individual depositors, although in the case of a run they may collectively receive less than originally promised. In Islamic banking the payoff to investment

\footnotetext{
${ }^{6}$ Deposits are received by Islamic banks in the form of "Qard Al-Hasan" or "Amanaa".
} 
account holders is contingent on both the performance of the bank as well as the religiosity of depositors. This can result in an ambiguous outcome - religious depositors may be more loyal and prepared to take lower returns, refusing (or at least stalling) from withdrawing deposits even if the performance of the bank deteriorates. Alternatively, religious depositors may be more risk averse showing greater sensitivity to bank's performance and demanding higher returns. In such a case investment account funding may be more fragile than time deposits, imposing greater discipline on Islamic banks.

The case where religious factors lead to lower withdrawal risk for investment account holders may influence Islamic banks' lending behavior. It may weaken their incentives for due diligence and loan monitoring, since Islamic banks can transfer credit risk to investment account holders who do not have the same rights as equity holders but share the same risk (Sundararajan and Errico, 2002). Alternatively, the special relationship can discipline Islamic banks more effectively (compared to conventional banks) since investment accounts holders have greater incentives to monitor Islamic bank performance. In such a case, Islamic depositors are more likely to shift their deposits from poor-performing banks to those offering higher returns or even to conventional banks. Hence, there could be greater potential for withdrawal risk (Khan and Ahmed, 2001) and as such depositors can discipline Islamic banks more actively.

Sharing the realized profit or loss with investment account holders may make Islamic banks more risky. On the upside, larger payouts to investment account holders may increase deposits and this can force bank shareholders to raise more equity capital in order to maintain capital ratios and prevent dilution of their ownership rights. Conversely, poor payouts may encourage deposit withdrawals leading to potential liquidity and (ultimately) solvency problems. 


\subsubsection{Islamic Banking: Principles and Practice}

Islamic banks, in practice, tend to deviate somewhat from the above mentioned financing principles and can operate similarly to conventional banks. Obaidullah (2005) claims that withdrawal risks may persuade management to vary from PLS principles by paying competitive market returns to investment account holders regardless of realized performance. Chong and Liu (2009) use Malaysian data to show that investment deposit rates of Islamic banks are closely linked to those of their conventional counterparts. They argue that competitive pressure from conventional banks constrains the actual implementation of PLS arrangements. This strategy can also help management to mitigate the sensitivity of investment account holders to bank's performance and hence avoid greater discipline.

In other words, equity-holders of Islamic banks can be at risk from transferring a part of their profits to investment account holders so as to reduce withdrawal risk. Such a risk is known as Displaced Commercial Risk (AAOIFI, 1999). Nevertheless, in the likelihood of crisis, management is highly likely to share realized losses with investment account holders to avoid insolvency. This suggests that Islamic banks may have a greater capacity to bear losses compared to conventional banks. The magnitude of the extra capacity depends on the weight of investment deposits in total funding. When Islamic banks are performing well they may adjust profit rates upward but at a slower rate than realized profitability so as to limit the level and volatility of deposit inflows.

Implicitly, investment account holders own a bond, a long position on a call option and a short position on a put option. The strike price of the call, however, is determined arbitrarily by Islamic banks, in the absence of supportive regulations on the account holders' rights. The strike price of the put is determined based on the degree of market competitive pressures, level of incurred loss and the capital ratio of the Islamic bank. Figure (1) illustrates how the special 
relationship between investment account holders and an individual Islamic bank works in theory and practice compared to holders of time deposits in a typical conventional bank.

\section{[FIGURE 1]}

\subsubsection{Assets}

In the process of lending, Islamic banks tend to apply non-PLS principles due to the risks and complexities associated with the PLS method. For instance, under PLS financing, Islamic banks need to determine the profit or loss sharing ratio for each project which can be complicated due to difficulties in quantifying the characteristics of clients and the proposed business opportunity. Revenue is not guaranteed and since they cannot collect collateral, they need to put more effort into selection and monitoring so as to ensure that informational rents are not extracted by borrowers. Hence, for short-term financing, it is not viable for Islamic banks to use the PLS method. Moreover, under the Mudarabah contract, Islamic banks have limited means to control and intervene in the management of a project ${ }^{7}$.

Aggarwal and Yousef (2000) find that Islamic banks mainly use Non-PLS instruments to avoid the moral hazard problem associated with PLS financing. Chong and Liu (2009) show that in Malaysia, only $0.5 \%$ of Islamic bank finance is based on PLS principles. Dar and Presley (2000) claim that even Mudarabah companies in Pakistan, which are supposed to operate in the form of PLS mainly follow Non-PLS modes of finance. This is also emphasized by Baele et al (2010). According to Bank Indonesia (2009) PLS modes of finance accounted for $35.7 \%$ in the financing of Islamic banks operating in the country by the end of 2008. The report points out that the use of the PLS method in Indonesia is among the highest compared to what is practiced in other countries. Mills and Presley (1999) also claim that PLS is only marginally practiced in

\footnotetext{
${ }^{7}$ Errico and Farahbakhsh (1998), Dar and Presley (2000) and Sundarajan and Errico (2002) discuss the complexity of the PLS method.
} 
Bangladesh, Egypt, Iran, Pakistan, Philippines and Sudan. However, while Islamic banks appear to refrain from practicing PLS modes of finance they still face possible greater withdrawal risks than conventional banks (Khan and Ahmad, 2001; and Sundararajan and Errico, 2002).

\subsubsection{Complexity of Islamic Modes of Finance}

Islamic financing agreements ${ }^{8}$, even for Non-PLS methods, are not as straightforward as conventional loan contracts (and according to anecdotal evidence also take longer to process). Generally, in debt-based or lease-based finance, such as Murabaha, Islamic banks arrange for the goods/projects to be purchased and then sell or rent them to clients. For purchase/implementation of the goods/projects, Islamic banks normally appoint the client as their agent. Such a framework is somewhat complicated as compared to conventional loan contracts. Sundarajan and Errico (2002) note the specific risks attached to various Non-PLS methods, such as Salam and Ijara. In the former, Islamic banks are exposed to both credit and commodity price risks; in the latter, unlike conventional lease contracts, Islamic banks cannot transfer ownership and therefore have to bear all the risks until the end of the lease period.

Another area of debate relates to the treatment of default penalties. Some jurisdictions rule that such penalties are not authorized by Shariá, ${ }^{9}$, so banks make use of rebates instead (Khan and Ahmed, 2001). Here the mark-up on the finance arrangement implicitly covers the return to the banks as well as a default penalty component. If the client repays the loan in a timely manner then they will receive the rebate. While default interest payments are typically calculated over the

\footnotetext{
${ }^{8}$ See Khan (1991), Khan (1992), Ahmad (1993) and Iqbal and Mirakhor (2007) for details on the features of various Islamic financial instruments.

${ }^{9}$ Islamic scholars generally consider the default penalty as the interest on debt which is prohibited by Sharia as explained in sub-section 1.1.; however, it is treated differently across countries. In Iran, for instance, default penalty is a penalty for non-fulfillment of a commitment and it should not be classified as the interest on debt. In Pakistan, Islamic experts have authorized the default penalty, only if it is spent on charity (Baele et al., 2010).
} 
delayed period in conventional banking, some Islamic banks collect the delayed penalty over the whole financing period. In addition, Islamic banks can also face restrictions regarding the use of derivatives as well as different types of collateral, for instance, they are not authorized to use interest-based assets, like bonds, for security (Khan and Ahmed, 2001).

\subsubsection{Investment Limitations}

In addition to lending, conventional banks also allocate a part of their funds to investments. Such investments normally include purchase of bonds (as well as instruments with shorter maturities) of different types that have risk/return features that help manage portfolio risk. However, Islamic banks have limited options for such investments since they are not authorized to invest in interest bearing instruments. Alternatively they can invest in Islamic bonds, known as Sukuk ${ }^{10}$. Although (like in short-term Islamic money markets) this asset class still remains relatively underdeveloped, limitations on Islamic bank investment opportunities have been weakened over time due to the expansion of alternative Islamic financing instruments.

\subsubsection{Relationship between Clients' Risk Aversion and Religiosity}

Since Islamic banking is characterized by observing Shariá requirements, clients with religious beliefs are more likely to prefer Islamic to conventional banking. In a dual banking system where both Islamic and conventional banking are practiced, the market is segmented: religious clients may choose Islamic banking, while others might be indifferent between Islamic and conventional banks. The existing literature shows a positive relationship between religiosity and an individual's risk aversion (Miller and Hoffmann, 1995; Osoba, 2003; Hilary and Hui,

\footnotetext{
${ }^{10}$ They are similar in nature to debt certificates, and can only be issued on the basis of the revenue which is expected to be generated by an underlying asset.
} 
2009).We have already noted that religiosity may affect the bank's lending from the liability side through the disciplinary role of deposits. It can also influence the bank's performance from the asset side by encouraging borrowers to fulfill their obligations under Islamic loan contracts. All in all, assuming all other factors equal, whether Islamic banks face more or less credit risk compared to conventional banks is likely to be influenced by the religious features of the client base.

Overall, Islamic banking is characterized by various features that appear on the one hand to reduce credit risk. Greater discipline associated with higher deposits fragility (exerted by depositors' risk aversion) and the religious beliefs of borrowers may induce loyalty and discourage default. On the other hand Islamic banks may face greater credit risk due a variety of factors such as: the complexity of Islamic loan contracts, limited default penalties and moral hazard incentives caused by PLS contracts. In terms of insolvency risk, the special relationship with depositors could provide Islamic banks with greater capacity to bear losses yet at the same time, operational limitations on investment and risk management activities could make them less stable than their conventional counterparts. Also, while interest is forbidden in Islamic banking, those institutions that compete with conventional banks may be forced to mirror their pricing behavior and as such may be sensitive to interest rate changes. Whether they have higher or lower sensitivity compared to conventional banks is an empirical question which we try to answer in this paper. Specifically we are interested in investigating whether Islamic bank's credit risk is more or less responsive to interest rate movements, taking into account the (expected) higher risk aversion of Islamic borrowers. We also examine the interest rate sensitivity of insolvency risk.

Understanding the risk features of Islamic versus conventional banks enables us to investigate whether Islamic banks extract special rents from clients for offering financial products that are compatible with their religious beliefs. Phrased differently, knowing the constraints of 
religious clients, Islamic banks may charge higher rates to borrowers and give lower rates to depositors. The extra rents would then be considered as the price of offering Shariá-compliant products.

During the Islamic Finance World North America conference (Toronto-2007), it was reported that at least one third of North American Muslims refuse conventional mortgages and are willing to pay more for religiously sound products. In Canada, Islamic mortgages are between 100-300 basis points more expensive than conventional mortgages. In the U.S. the spread is 40 to 100 basis points ${ }^{11}$. Baele et al (2010) find that in Pakistan, the interest (mark-up) rate is, on average, two percentage points higher for Islamic than for conventional loans, even though the default probability of the former is lower. However, Weill (2011), using a sample of 1,301 observations for 34 Islamic and 230 conventional banks operating in 17 OIC member countries between 2001 and 2007, computes Lerner indices and finds that Islamic banks have lower price mark-ups (market power) than conventional banks.

\section{Methodology and Econometric Specifications}

Our methodology compares the risk features of Islamic and conventional banks while controlling for a variety of potentially influential factors. A similar approach is used to investigate whether Islamic banks extract special rents from their clients. We believe that Islamic and traditional banks can be compared as previous literature (Chong and Liu, 2009) has found that the former can mimic the latter in terms of financial behavior notwithstanding operational differences (Islamic contracts, PLS arrangements and so on) that can cause risk divergence. The following three model specifications are estimated:

11 See http://www.canada.com/nationalpost/financialpost/story.html?id=01ff2407-f4fe-4c16-80ad$1172 \mathrm{~d} 0 \mathrm{~d} 25763 \& \mathrm{k}=5052$. 
Credit_Risk $\mathrm{i}_{\mathrm{t}, \mathrm{t}}=\alpha_{0}+\alpha_{1} \times$ Islamic_Bank $_{\mathrm{i}, \mathrm{t}}+\alpha_{2} \times$ Islamic_Window_Bank $_{\mathrm{i}, \mathrm{t}}+\alpha_{3} \times$ Size $_{\mathrm{i}, \mathrm{t}-1}+$

$\alpha_{4} \times$ Market_Share ${ }_{i, t-1}+\alpha_{5} \times$ Capital_Asset_Ratio ${ }_{i, t-1}+\alpha_{6} \times$ Loan_Growth $_{\mathrm{i}, \mathrm{t}-1}+$

$\alpha_{7} \times$ Noninterest_Income $_{\mathrm{i}, \mathrm{t}-1}+\alpha_{8} \times$ Cost_Inefficiency $_{\mathrm{i}, \mathrm{t}-1}+\alpha_{9} \times$ State_Bank $_{\mathrm{i}, \mathrm{t}}+\alpha_{10} \times$ Foreign_Bank $_{\mathrm{i}, \mathrm{t}}+$

$\alpha_{11} \times$ Subsidiary $_{\mathrm{i}, \mathrm{t}}+\alpha_{12} \times$ Young_Bank $_{\mathrm{i}, \mathrm{t}}+\alpha_{13} \times$ Middle_Aged_Bank $_{\mathrm{i}, \mathrm{t}}+\alpha_{14} \times$ Muslim_Share $_{\mathrm{i}}+$

$\alpha_{15} \times$ Domestic_Interest_Rate $\mathrm{i}_{\mathrm{i}, \mathrm{t}-1}+\alpha_{16} \times \mathrm{HHI}_{\mathrm{i}, \mathrm{t}-1}+\alpha_{17} \times$ GDP_Per_Capita $\mathrm{i}_{\mathrm{i}, \mathrm{t}-1}+\alpha_{18} \times$ GDP_Per_Capita_Growth ${ }_{\mathrm{i}, \mathrm{t}-1}+$

$\sum_{y=1}^{9} \alpha_{19, \mathrm{y}} \times$ Year_Dummies $_{\mathrm{t}, \mathrm{y}}+\sum_{c=1}^{23} \alpha_{20, \mathrm{c}} \times$ Country_Dummies $_{\mathrm{i}, \mathrm{c}}+\varepsilon_{\mathrm{i}, \mathrm{t}}$

Insolvency_Risk $\mathrm{i}_{\mathrm{i}, \mathrm{t}}=\beta_{0}+\beta_{1} \times$ Islamic_Bank $_{\mathrm{i}, \mathrm{t}}+\beta_{2} \times$ Islamic_Window_Bank $\mathrm{i}_{\mathrm{i}, \mathrm{t}}+\beta_{3} \times$ Size $_{\mathrm{i}, \mathrm{t}-1}+$

$\beta_{4} \times$ Market_Share i,t-1 $+\beta_{5} \times$ Loan_Total_Earning_Asset_Ratio ${ }_{\mathrm{i}, \mathrm{t}-1}+\beta_{6} \times$ Asset_Growth $_{\mathrm{i}, \mathrm{t}-1}+$

$\beta_{7} \times$ Noninterest_Income $_{\mathrm{i}, \mathrm{t}-1}+\beta_{8} \times$ Cost_Inefficiency $_{\mathrm{i}, \mathrm{t}-1}+\beta_{9} \times$ State_Bank $_{\mathrm{i}, \mathrm{t}}+\beta_{10} \times$ Foreign_Bank $_{\mathrm{i}, \mathrm{t}}+$

$\beta_{11} \times$ Subsidiary $_{\mathrm{i}, \mathrm{t}}+\beta_{12} \times$ Young_Bank $_{\mathrm{i}, \mathrm{t}}+\beta_{13} \times$ Middle_Aged_Bank $_{\mathrm{i}, \mathrm{t}}+\beta_{14} \times$ Muslim_Share $_{\mathrm{i}}+$

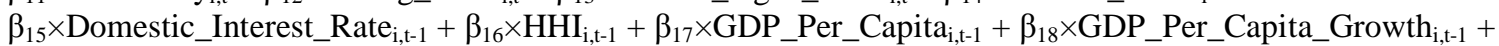

$\sum_{y=1}^{9} \beta_{19, \mathrm{y}} \times$ Year_Dummies $\mathrm{t,y}+\sum_{c=1}^{23} \beta_{20, \mathrm{c}} \times$ Country_Dummies $_{\mathrm{i}, \mathrm{c}}+\eta_{\mathrm{i}, \mathrm{t}}$

Bank_Interest_Rate ${ }_{i, \mathrm{t}}=\gamma_{0}+\gamma_{1} \times$ Islamic_Bank $_{\mathrm{i}, \mathrm{t}}+\gamma_{2} \times$ Islamic_Window_Bank $_{\mathrm{i}, \mathrm{t}}+\gamma_{3} \times$ Size $_{\mathrm{i}, \mathrm{t}-1}+$ $\gamma_{4} \times$ Market_Share $_{\mathrm{i}, \mathrm{t}-1}+\gamma_{5} \times$ Capital_Asset_Ratio $_{\mathrm{i}, \mathrm{t}-1}+\gamma_{6} \times$ Noninterest_Income $_{\mathrm{i}, \mathrm{t}-1}+\gamma_{7} \times$ Cost_Inefficiency $_{\mathrm{i}, \mathrm{t}-1}+$ $\gamma_{8} \times$ Credit_Risk $\mathrm{i}_{\mathrm{i}, \mathrm{-}-1}+\gamma_{9} \times$ State_Bank $_{\mathrm{i}, \mathrm{t}}+\gamma_{10} \times$ Foreign_Bank $_{\mathrm{i}, \mathrm{t}}+\gamma_{11} \times$ Subsidiary $_{\mathrm{i}, \mathrm{t}}+\gamma_{12} \times$ Young_Bank $_{\mathrm{i}, \mathrm{t}}+$ $\gamma_{13} \times$ Middle_Aged_Bank $\mathrm{i}_{\mathrm{i}, \mathrm{t}}+\gamma_{14} \times$ Muslim_Share $_{\mathrm{i}}+\gamma_{15} \times$ Domestic_Interest_Rate $_{\mathrm{i}, \mathrm{t}-1}+\gamma_{16} \times \mathrm{HHI}_{\mathrm{i}, \mathrm{t}-1}+$ $\gamma_{17} \times$ GDP_Per_Capita $\mathrm{i}_{\mathrm{i}, \mathrm{-}-1}+\gamma_{18} \times \mathrm{GDP}_{-}$Per_Capita_Growth $\mathrm{i}_{\mathrm{i}, \mathrm{t}-1}+\sum_{y=1}^{\overline{9}} \gamma_{19, \mathrm{y}} \times$ Year_Dummies $_{\mathrm{t}, \mathrm{y}}+\sum_{c=1}^{23} \gamma_{20, \mathrm{c}} \times$ Country_Dummies $\mathrm{i}_{\mathrm{i}, \mathrm{c}}+\Theta_{\mathrm{i}, \mathrm{t}}$

Where i subscripts denote individual banks and $t$ denotes the time dimension. Credit risk, insolvency risk and bank interest rates are modeled in Equations (1) to (3), respectively. Credit risk relates to loan quality, insolvency risk represents a bank's stability and the interest rate model is expected to capture any special rents extracted by Islamic banks from their clients.

The first and second Equations enable us to compare credit and insolvency risks of Islamic versus conventional banks, using a dummy variable which takes the value of one when a bank is Islamic and zero otherwise (Islamic_Bank). Islamic window banks are also represented by a dummy variable (Islamic_Window_Bank $)^{12}$. Hence, conventional banks are considered the benchmark. The third Equation aims to investigate whether Islamic banks charge rents (compared to conventional banks) for their Shariá compliant services. Simply, Equation (3) analyzes the determinants of a range of interest rate measures (net interest margin, interest income and interest

\footnotetext{
${ }^{12}$ Controlling for Islamic window banks enables us to compare fully Islamic versus fully conventional banks. It would have been interesting to compare the credit risk of conventional and Islamic windows of the same bank, but due to data unavailability this was not feasible.
} 
expense - including Islamic equivalents) to test for Islamic bank rent seeking behavior ${ }^{13}$. Higher net interest margin or implicit interest income rates on loans (or lower implicit interest expense on deposits) would suggest that Islamic banks extract rents from their clients for offering Islamic products/services.

The established literature shows that interest rate changes can affect banks' soundness through changes in banks' asset quality (Jarrow and Turnbull, 2000; Carling et al., 2007; Drehmann et al., 2010 and Alessandri and Drehmann, 2010). In our analysis, therefore we study the influence of domestic interest rates through three channels: its impact on credit risk (Equation 1), insolvency risk (Equation 2) and on various bank-level interest rate prices (Equation 3). For the first channel, we include interest rates in our model of credit risk and also add an interest rate and Islamic bank dummy interaction term - this shows the sensitivity of Islamic banks' credit risk to interest rate variation. The second channel (Equation 2) explores whether the insolvency risk of Islamic banks has a different sensitivity to interest rates compared to conventional banks. For the third channel, we examine the determinants of a variety of bank-level interest rate (implicit and explicit) prices including: net interest margin, interest income and expense (as well as loan and deposit rates) using a set of controls and explanatory variables. Similar to the previous channels, the interaction term of our interest rate variable and the Islamic bank dummy shows whether earnings and expenses of Islamic banks are more or less exposed to interest rate variation than their conventional counterparts. The model also tests for possible rent seeking behavior in Islamic banking using the variety of implicit and explicit interest rate dependent variables and the Islamic bank dummy.

\footnotetext{
13 The specification of Equation 3 is based on the bank interest margin literature (Angbazo, 1997; Wong, 1997; Maudos and De Guevara, 2004; Carbo and Rodriguez (2007) and Lepetit et al. (2008b).
} 


\subsection{DEPENDENT VARIABLES}

We primarily use the ratio of loan-loss reserves to gross loans (Loan_Loss_Reserve) as a proxy for credit risk (Credit_Risk). This variable represents managers' assessment of the quality of the loan portfolio, including performing and non-performing loans. Loan_Loss_Reserve takes into account the past performance and the expectation for future performance of the existing loan portfolio (a bank may have lower non-performing loans simply because the repayment period of the major part of its loan portfolio has not yet started). Its periodic adjustment is reflected in the income statement in the form of loan loss provision. As a robustness check we also employ the ratio of impaired loans to gross loans (Impaired_Loans) and the ratio of loan-loss provisions to average gross loans (Loan_Loss_Provision) both backward-looking proxies for credit risk. All three proxies represent the quality of bank's existing loans and are widely used in the empirical banking literature (for instance, Angbazo, 1997; Kwan and Eisenbeis, 1997; Shiers, 2002; Konishi and Yasuda, 2002; Cebenoyan and Strahan, 2004; Gonzalez, 2005; Altunbas et al., 2007 and Lepetit et al., 2008a). It should be noted, however, that these indicators of credit risk only partly reflect the quality of the loan portfolio, since variation across banks may be due to different internal policies regarding problem loan classification, reserve requirements and write-off policies.

For insolvency risk analysis, we employ the Zscore measure which is widely used in the literature as a stability indicator (see, for instance, Goyeau and Tarazi, 1992; Boyd and Runkle, 1993; Lepetit et al., 2008a; Hesse and Čihák, 2007; Čihák et al., 2009; Laeven and Levine, 2009; Čihák and Hesse, 2010). Using accounting information on asset returns, its volatility and leverage, the Zscore is calculated as follows: Zscore $=\frac{E(R O A)+C A R}{S D(R O A)}$, where $\mathrm{E}(\mathrm{ROA})$ is the expected return on assets, $C A R$ is the ratio of equity capital to assets and $\operatorname{SD}(\mathrm{ROA})$ is the 
standard deviation of ROA. Zscore is inversely related to the probability of a bank's insolvency. A bank becomes insolvent when its asset value drops below its debt. The insolvency probability can be written as $\mathrm{P}(\mathrm{ROA}<-\mathrm{CAR})$. If we use the standardized ROA, the probability would be

equal to $P\left(\frac{R O A-E(R O A)}{S D(R O A)}<-Z\right.$ score $)$. Hence the Zscore shows the number of standard deviation that a bank's return has to fall below its expected value to deplete equity and make the bank insolvent. A higher Zscore implies that the bank is more stable. To control for outliers and skewness of the distribution, we use the logarithm of the Zscore and its components.

Finally, we examine whether Islamic banks charge rents to their clients, in the form of charging higher rates to borrowers or offering lower rates to depositors. First, we use net interest margins (Net_Interest_Margin) that may capture rents collectively on both the loan and deposits sides. As further robustness checks, we also use the implicit interest income rate (Interest_Income_Rate), implicit interest expense rate (Interest_Expense_Rate), implicit interest rate on loans (Loan_Rate) and the implicit interest rate on deposits (Deposit_Rate). It is worth noting that while Islamic banks do not pay or earn interest, they do charge their clients a mark-up which is equivalent (similar) to interest in conventional banking. Annex 1 defines our risk proxies and control variables.

\subsection{CONTROL VARIABLES}

Islamic_Bank and Islamic_Window_Bank are dummies for Islamic banks and windows, respectively. A variety of other control variables are included in the estimation of our models: Size, Market_Share, Capital_Asset_Ratio, Loan_Total_Earning_Asset_Ratio, Loan_Growth, Asset_Growth, Noninterest_Income and Cost_Inefficiency. We also control for: 
- Ownership structure, using three dummy variables: State_Bank, Foreign_Bank and Subsidiary;

- Bank age or experience level, using two dummies: Young_Bank and Middle_Aged_Bank;

- Macroeconomic indicators: Muslim_Share, Domestic_Interest_Rate, HHI, GDP_Per_Capita and GDP_Per_Capita_Growth;

- Year and country dummies.

The rationale for their inclusion is set-out below.

The logarithm of total asset is considered as a proxy for size (Size). Large banks can benefit from both scale economies and diversification as claimed by Hughes et al. (2001). At the same time, larger banks might be more risky, since they may try and exploit Too-Big-To-Fail safety net subsidies (Kane, 2010). Market share measured as bank assets over total banking sector assets (Market_Share) is used as the proxy for market power (as in Berger, 1995).

The share of equity capital in total assets (Capital_Asset_Ratio) is included in the first (Credit_Risk) and the third (Bank_Interest_Rate) Equations ${ }^{14}$. We include Capital_Asset_Ratio in the credit risk Equation, since on the one hand, an increase in equity can lower moral hazard problems and increase the monitoring incentives of banks (Diamond, 1984). On the other hand, higher equity can increase banks' risk-taking capacity. This variable is included as it allows us to investigate whether the relationship between equity capital and risk varies between Islamic and conventional banks. Capital_Asset_Ratio is also used in the Bank_Interest_Rate Equation, as previous studies on the determinants of margins suggest a positive relationship (Carbo and Rodriguez, 2007). Equity can be considered as a risk aversion proxy (McShane and Sharpe, 1985 and Maudos and De Guevara, 2004) and banks with higher equity expect higher returns.

\footnotetext{
${ }^{14}$ This is not incorporated in the second equation, since our insolvency risk proxy accounts for the degree of leverage.
} 
Islamic banks can have various limitations in their investment of other earning assets (section (1.2.5.)) which may adversely affect their stability. Hence, we include the share of net loans in total earning assets (Loan_Total_Earning_Asset_Ratio) in the second model to investigate the extent to which the composition of total earning assets impacts on insolvency risk.

The growth rate of gross loans (Loan_Growth) is controlled for in the credit risk Equation since a considerable increase in credit may reflect weaker screening standards, relaxed collateral requirements or lower interest rates (Dell'Ariccia and Marquez, 2006; Ogura, 2006). Clair (1992) finds a negative effect of credit expansion on non-performing loans and loan chargeoff rates, although for subsequent years a positive link is detected. As pointed out by Berger and Udell (2004) and Foos et al. (2010) borrowers do not default immediately after taking-on loans. For insolvency risk analysis, as we need to take into account the growth strategy of banks, we use total asset growth (Asset_Growth) in lieu of loan growth.

Share of non-interest income in total operating income (Noninterest Income) and cost inefficiency are included in all three models. A bank may lose its focus on loan activity as it moves towards noninterest income businesses. Alternatively, the expanding scope of activities may improve a bank's position in lending as it can collect valuable information from different business lines that can be used for lending. According to previous studies, an increase in the share of non-interest income in total operating income is expected to lower stability. DeYoung and Roland (2001) and Stiroh (2004, 2006, 2010), for instance, claim that the increased reliance on non-interest income has raised the volatility of bank portfolios without increasing average profits. Lepetit et al. (2008a) show that European banks with a higher non-interest income share in their net operating income, exhibit a higher insolvency risk. The share of noninterest income in total operating income is also included in the third Equation, as Carbo and Rodriguez (2007) and Lepetit et al. (2008b) show that noninterest income enables banks to lower margins. 
Kwan and Eisenbeis (1997) show that inefficiency increases bank risks - illustrating moral hazard that poorly-run banks have greater incentives for risk-taking. Hence, we control for cost inefficiency (Cost_Inefficiency) using the cost to income ratio in our credit and insolvency Equations ${ }^{15}$. A bank with greater cost inefficiency needs to have higher net interest margins to compensate for losses incurred due to inefficiency. Thus, Cost_Inefficiency is included in the Bank_Interest_Rate Equation. In the third Equation, we also control for credit risk, using the Loan_Loss_Reserve proxy, which has been found to be a determinant of interest margins (Angbazo, 1997; Wong, 1997; Maudos and De Guevara, 2004; Carbo and Rodriguez, 2007).

Bank ownership structure should also be taken into account. La Porta et al. (2002) analyze government ownership of large banks in 92 countries and show that it reduces efficiency. Bonin et al. (2005) investigate the impact of ownership on bank efficiency for eleven transition countries and find that foreign-owned banks are more cost efficient than other banks. Iannotta et al. (2007) using a sample of 181 large banks from 15 European countries claim that state-owned banks have poorer loan quality and higher insolvency risk than other types of banks ${ }^{16}$. In our model, we classify banks into four categories ${ }^{17}$ : domestic privately-owned banks, domestic state-

\footnotetext{
${ }^{15}$ See Mohamad et al. (2008) for a cross-country study of Islamic versus conventional banks using the stochastic frontier approach and a sample of 37 conventional and 43 Islamic banks operating in 21 OIC member countries for the 1990-2005 period. They find no significant difference in terms of efficiency between Islamic and conventional banks; however, Abdul-Majid et al. (2010) apply a distance function approach and find that Islamic banks are less technically efficient than their conventional counterparts. They use a sample of 558 observations covering 23 Islamic and 88 conventional banks that operate in 10 OIC member countries over 1996 and 2002. Beck et al (2010) use more conventional measures of bank efficiency - overhead costs and the cost-to-income ratio. Starting with a sample of 2,956 banks (of which 99 are Islamic) from 141 countries between 1995 and 2007. Islamic banks appear more efficient than their conventional counterparts. However, when they examine data from the 22 countries where Islamic and conventional banks compete together they find that Islamic banks have significantly higher overhead costs but only slightly higher cost to income ratio compared to conventional banks.

${ }^{16}$ For a discussion of empirical investigation of ownership issues in banking see Altunbas et al. (2001) and Goddard et al. (2004). More recent studies include Barry et al. (2011), Taboada (2011), Forssbæck (2011) and Berger et al. (2009).

${ }^{17}$ We classify a bank as a state-owned bank when at least fifty percent of the equity belongs to the government. Similarly, at least fifty percent of a bank should be owned by one or more foreign entity(ies) to be classified as a foreign-owned bank. A bank which is owned by a foreign government is considered as a foreign-owned bank. We
} 
owned banks (State_Bank), foreign-owned banks (Foreign_Bank) and subsidiaries (Subsidiary). Domestic privately-owned banks are used as the benchmark and hence three dummies are introduced to represent the other banks.

State-owned banks may invest in risky projects as a result of political influence, or/and they may also enjoy some benefits and informational rents from political bodies. Foreign-owners can face greater risk in monitoring the bank's activities since they may be less familiar with the legal and judicial setting in which they operate. Alternatively, due to such problems they may pursue relatively conservative strategies. A subsidiary might structure a risky portfolio of loans, simply because such a portfolio can beneficially contribute to diversification of the parent's overall portfolio. Failure of a subsidiary may not be viewed as undesirable in the event of a crisis if reputational risks are low.

We also consider the age of the bank by defining two dummy variables. Banks with at least three years of operation are categorized as young banks (Young_Bank) and those which have been operating for a period ranging from three to seven years are considered as middle aged (Middle_Aged_Bank). Other banks, called mature banks, are considered as the benchmark. The age of banks is expected to proxy for experience and informational advantages. Older banks are likely to have longer term relationships and other informational advantages (experience operating in new geographies and product markets) that are reflected in efficiency and risk advantages. Of course, it could be the case that younger institutions have tougher regulatory oversight and therefore operate more cautiously.

We also introduce five country level variables to control for cross-country variations. First we control for the degree of religiosity, using two interchangeable proxies: the share of Muslim

assume that although a government may decide to invest in a bank abroad based on political ties with the host country, it will not intervene in the bank's operation as intensively as the host country's government. 
population in each country (Muslim_Share) and an index representing the country's legal system (Legal_System). In the latter case, the index takes a value of zero for countries which do not use Shariá law to define their legal system, a value of one for those countries that have legal systems based on both Shariá and other legal traditions (such as English or French laws); and finally, the index has a value of two for countries with exclusive Shariá based legal systems (such as Iran and Saudi Arabia).

We also control for the level of domestic interest rates (Domestic_Interest_Rate). The existing literature shows that the level of domestic interest rates can influence banks' risk appetite (Dell' Ariccia and Marquez, 2006; Rajan, 2006; Borio and Zhu, 2008; Delis and Kouretas, 2010; Maddaloni and Peydró, 2011). Typically, banks are found to have a higher risk-taking appetite when interest rates are low. However, interest rate levels can influence the ability of borrowers to re-pay (Jarrow and Turnbull, 2000; Carling et al., 2007; Drehmann et al., 2010 and Alessandri and Drehmann, 2010) - at higher levels the incentive to default (moral hazard) increases. We try to capture the possible impact of banking sector concentration on risk-taking behavior by including the Herfindahl-Hirschman Index $(H H I)$ in the model. Finally, we control for the level and growth in the prosperity of the population by including the following variables - GDP per capita (GDP_Per_Capita) and growth in GDP per capita (GDP_Per_Capita_Growth). Year dummies are introduced to control for time fixed effects ${ }^{18}$ and we also include country dummies to capture heterogeneity across different banking systems ${ }^{19}$.

\footnotetext{
${ }^{18}$ The sample covers eleven years, however, since all accounting and macro level variables are lagged for one year, we use nine year dummies (2001-2009) in our estimations.

${ }^{19}$ This is particularly important due to differences in the nature of Islamic banking across countries. Unfortunately, our data does not enable us to construct an index reflecting the degree of difference between Islamic and conventional banks in each country. Nevertheless, we control for this dimension by introducing 23 country dummy variables. It is worth noting that since Muslim_Share and Legal_System are time-invariant country level variables, we use country dummies and Muslim_Share / Legal_System interchangeably to avoid perfect multi-collinearity.
} 


\section{Data and Descriptive Statistics}

Bank-level data was retrieved from the Bankscope database and the web sites of individual banks. Country-level variables, including domestic interest rate ${ }^{20}$, GDP per capita and the growth rate of GDP per capita are collected from the World Bank web-site. The share of Muslim population in each country is obtained from Pew Research Center $^{21}$ and the data on legal systems are obtained from the World Factbook. The Bankscope classification for Islamic banks is incorrect in places so all banks have been cross-checked with their websites to ensure accuracy ${ }^{22}$. The sample covers 3870 observations for 553 commercial banks, across 24 country $^{23}$ members of the OIC where Islamic banking is practiced over the period 1999 to 2009 (see Table A in Annex 2 for a detailed summary of cross-country and bank type specifications). Our sample comprises 118 Islamic commercial banks, 81 commercial banks with Islamic window/branches and 354 conventional commercial banks. For Iran, observations are only available for Islamic banks as its banking system is $100 \%$ Riba-free. In other countries, both Islamic and conventional banking are authorized and practiced. The largest number of observations is from Indonesia and the lowest from Brunei. Approximately, $20 \%$ of the total observations are for Islamic banks; Islamic window banks represent $17 \%$ of the sample (the remaining $63 \%$ relate to conventional banks). Table B in Annex 2 shows the ownership structure and age (experience level) of banks in our sample. The data reveal that Islamic banks are relatively younger than conventional banks and

\footnotetext{
${ }^{20}$ We use deposit interest rate announced by the World Bank; for years and countries with missing observations, the data is obtained from the web-site of central banks.

${ }^{21}$ Please visit http://pewforum.org/Mapping-the-Global-Muslim-Population.aspx

${ }^{22}$ Bankscope classifies banks as commercial, Islamic or other types. However an Islamic bank can be a commercial or a non-commercial bank. Such a classification is problematic: (1) In Bankscope some Islamic banks are mistakenly categorized as commercial banks. (2) Some Islamic banks are investment banks or other types that are not comparable with commercial banks. (3) The data-set also does not differentiate conventional banks with Islamic windows from Islamic or conventional banks.

${ }^{23}$ Algeria, Bahrain, Bangladesh, Brunei, Egypt, Gambia, Indonesia, Iran, Iraq, Jordan, Kuwait, Lebanon, Malaysia, Mauritania, Pakistan, Qatar, Saudi Arabia, Senegal, Syria, Sudan, Tunisia, Turkey, UAE and Yemen.
} 
also the number with foreign owners is proportionately higher. Annex 3 also shows the macroeconomic and banking indicators for the countries under study.

Table II illustrates sample descriptive statistics. It shows that relatively large conventional banks establish Islamic windows. Islamic banks are, on average, more capitalized and profitable than conventional banks. The lower levels of debt (possibly as a response to higher withdrawal risk) and higher non-interest income of Islamic banks might partly explain their greater profitability. Net interest margin of Islamic banks does not appear to be significantly different from that of conventional banks; however, Islamic banks have lower implicit interest income and expense rates than conventional banks. Interestingly, the structure of the asset portfolio of Islamic banks is significantly different from that of conventional banks. Islamic banks have a higher ratio of net loans to total earning assets possibly because they are limited in their investments in other earning assets (such as bonds) as discussed in section (1.2.5.). Gross loans and total assets grow at higher rates for Islamic than conventional banks. The cost to income ratio of Islamic banks is slightly higher than that of conventional banks.

The descriptive statistics of our risk measures show that Islamic banks have lower levels of credit risk compared to conventional banks. In terms of insolvency risk the mean test results show that the Zscore and its components for Islamic banks are not significantly different from those of conventional banks, suggesting that the higher returns and capital of Islamic banks are offset by their higher asset return volatility.

\section{[TABLE II]}

A correlation matrix is presented in Annex 4 which does not suggest any major collinearity problems among our independent variables, except for the logarithm of total assets and market share variables. As a result, we orthogonalize the logarithm of market share on the logarithm of total assets. 


\section{Empirical Results}

\subsection{CREDIT RISK}

Table III presents the results for credit risk (Equation (1)) where we first use Loan_Loss_Reserve as the credit risk proxy. The Equation is estimated using random effects ${ }^{24}$. In column (1), the credit risk proxy is regressed simply on our Islamic bank and Islamic window dummy variables (Islamic_Bank \& Islamic_Window_Bank). Different classes of control variables, including financial structure, ownership structure, age, macroeconomic indicators, year and country dummies, are included in columns (2) to (6). These improve the explanatory power of our model with R-squared increasing from 0.007 to $0.182^{25}$. In all specifications, Islamic banks, on average, exhibit lower credit risk than conventional banks. The results remain unchanged when we use Impaired_Loans and Loan_Loss_Provision as the credit risk proxies in lieu of Loan_Loss_Reserve. As a further robustness check, we assume within country correlation of standard errors, using clustered standard errors, and find similar results ${ }^{26}$. Islamic banks, on average, hold $3.037 \%$ less reserves for their loans than conventional banks. The average loan-loss reserves on gross loans for conventional banks is $8.72 \%$ (Table II) so Islamic banks hold $34.8 \%$ $\left(100 \times \frac{3.037}{8.72}\right)$ less than the average Loan_Loss_Reserve that conventional banks hold. Interestingly, the figure is close to Baele et al's (2010) finding that the hazard rate of Islamic loans is, on average, $33 \%$ lower than the hazard rate of conventional loans.

\footnotetext{
${ }^{24}$ We have several dummy variables that rarely change over time, namely, Islamic_Bank, Islamic_Window_Bank, State_Bank, Foreign_Bank and Subsidiary and so these variables have limited within variation. We also have time invariant variables (Muslim_Share, for instance). Fixed effects estimation is inefficient at estimating variables with limited within variance and cannot be used with time invariant variables. As such we employ the random effects technique in our estimation.

${ }^{25}$ The explanatory power of our models is close to similar studies, for instance Beck et al., 2009 and Čihák and Hesse, 2010.

${ }^{26}$ The results are available from the authors upon request.
} 
The results show a negative relationship between size and credit risk, which is consistent with possible diversification and scale economies benefits. Loan growth is associated with lower credit risk in the following year as also identified by Clair (1992). We also find that higher domestic interest rates have a positive influence on credit risk (loans are more difficult to repay if rates are higher).

Islamic banks may have lower credit risk compared to conventional banks due to the religiosity of clients that enhances loyalty and mitigates default and/or due to their special relationship with their depositors. To investigate the former we include an interaction term for the Islamic bank dummy and Muslim share in population (Islamic_Bank $\times$ Muslim_Share) reported in column (7). The result shows that there is a negative relationship between the credit risk of Islamic banks and the share of Muslims in the population. We find similar results (reported in column (8)) when we use Legal_System in lieu of Muslim_Share as the religiosity proxy. In column (9) the model now includes the Islamic bank/domestic interest rate interaction term $($ Islamic_Bank $\times$ Domestic_Interest_Rate) and here we find that the credit risk of Islamic banks is not significantly sensitive to domestic interest rates, while a one percent increase in domestic rates (on average) is associated with 0.232 percent increase in the Loan_Loss_Reserve of conventional banks. To analyze whether the relationship between Islamic banks and their depositors can explain the higher loan quality of Islamic banks we include the interaction term of the Islamic bank dummy and capital to asset ratio (Islamic_Bank $\times$ Capital_Asset_Ratio) and report the estimation in column (10). The result shows that higher leverage is associated with lower credit risk for Islamic compared to conventional banks.

We find a negative relationship between leverage and credit risk and also see that size and leverage are linked in a similar manner. As we expect, there is a negative relationship between bank assets size and clients' religiosity (larger Islamic banks may move toward bigger clients less 
sensitive to religious concerns). Moreover, Čihák and Hesse (2010) attribute the negative size effect on Islamic bank stability to risk management limitations. In order to investigate this issue further we include an interacted Islamic bank dummy with bank asset size (Islamic_Bank $\times$ Size) and report findings in column (11). The result shows that size has a negative impact on credit risk of Islamic banks, although the coefficient is significant only at the $10 \%$ level (possibly due to the negative relationship between size and leverage).

\section{[TABLE III]}

\subsection{INSOLVENCY RISK}

Table IV reports the insolvency risk Equation again estimated using random effects. In columns (1) to (6), we regress the insolvency risk prox ${ }^{27}$ on our Islamic bank and Islamic window bank dummy variables (Islamic_Bank \& Islamic_Window_Bank), while adding different classes of control variables in each step. Overall, we find no significant difference between Islamic and conventional banks in terms of insolvency risk ${ }^{28}$. The results also show that higher levels of non-interest income, cost inefficiency, share of Muslims in population, domestic interest rates and GDP per capita are associated with lower bank stability. In terms of ownership structure, we find that subsidiaries are less stable than domestic privately-owned banks. The results also show that young banks are less stable than their more mature counterparts.

In columns 7 and 8 we report results where we replace the Zscore by the logarithm of its first and second components and find no significant difference between Islamic and conventional

\footnotetext{
${ }^{27}$ We use the logarithm of Zscore "Zscore" as the insolvency risk proxy; we find similar results when we employ the absolute value of Zscore in our analysis, except that in one specification (when we control for all other factors) Islamic banks exhibit higher stability than conventional banks at the $10 \%$ significance level, which is due to their higher capitalization. Results are not presented here; they are available from the authors upon request.

${ }^{28}$ We find similar results when we use clustered standard errors, assuming within country correlation of standard errors. The results are available from the authors upon request.
} 
banks. To investigate the possible impact of the religiosity of Islamic banks' clients on stability, in column (9), we add the interaction terms of Islamic bank dummy variable and Muslim share in population (Islamic_Bank $\times$ Muslim_Share). The result shows no significant difference between Islamic and conventional banks ${ }^{29}$. In columns (10), the interaction term of Islamic bank dummy variable and interest rate (Islamic_Bank $\times$ Domestic_Interest_Rate) is included and we find no significant difference between Islamic and conventional banks in terms of sensitivity to interest rate changes. In column (11), we add the interaction term of Islamic bank dummy variable and size (Islamic_Bank $\times$ Size), to investigate the size effect on insolvency risk of Islamic banks. The result shows no significant difference between Islamic and conventional banks and again this is supported in column (12), where we include the Islamic bank dummy and share of loans in total earning assets interaction variable (Islamic_Bank $\times$ Loan_Total_Earning_Asset_Ratio). The composition of total earning assets does not appear to have a significantly different impact on Islamic banks' stability compared to conventional banks.

\section{[TABLE IV]}

\subsection{BANK INTEREST RATES}

Table V illustrates estimates of Equation (3) using random effects. Column (1) shows net interest margin (Net_Interest_Margin) regressed on the Islamic bank and Islamic window dummy variables (Islamic_Bank \& Islamic_Window_Bank) and a range of controls that include various financial variables, ownership structure, age dummies, macroeconomic indicators, year and country dummies. The result shows no significant difference between Islamic and conventional banks. In columns (2) to (5), we replace net interest margin with the implicit interest income rate

\footnotetext{
${ }^{29}$ We get similar results when we use Legal_System variable in lieu of Muslim_Share as the religiosity proxy, which is not reported here, but is available upon request.
} 
(Interest_Income_Rate), implicit interest expense rate (Interest_Expense_Rate), implicit interest rate on loans (Loan_Rate) and implicit interest rate on deposits (Deposit_Rate) respectively. Overall, we find little evidence that Islamic banks charge any special rent to their clients for offering Shariá-compliant products ${ }^{30}$. We also find a positive impact of domestic interest rates on net interest margins, implicit interest income and expense rates as well as on implicit interest rate on deposits.

In columns (6) to (10), we include the interaction term of domestic interest rate and the Islamic bank dummy (Islamic_Bank $\times$ Domestic_Interest_Rate) to investigate the sensitivity of Islamic banks' earnings and expenses to domestic interest rates compared to conventional banks. The results show no significant difference between Islamic and conventional banks in terms of the sensitivity of net interest margin, implicit interest rate on loans and implicit interest rate on deposits to domestic interest rates. We do find, however, that implicit interest income and implicit interest expense rates of Islamic banks are less sensitive to domestic interest rate levels than for conventional counterparts.

\section{[TABLE V]}

\subsection{ROBUSTNESS CHECKS AND FURTHER ISSUES}

\subsubsection{Credit Risk}

In order to confirm our findings, we undertake a number of robustness checks. We find that Islamic banks operating in countries with greater shares of Muslims in the population are less exposed to credit risk than conventional banks. For further analysis, we re-estimate our credit risk model for country sub-samples that have more than $90 \%$ Muslim populations (Muslim+90) and

\footnotetext{
${ }^{30}$ As a robustness check, we assume within country correlation of standard errors, using clustered standard errors, and find similar results. The results are available from authors upon request.
} 
those with smaller populations (Muslim-90) shown in Annex 5 columns (1) and (2) respectively ${ }^{31}$. The results show that Islamic banks are less exposed to credit risk only in Muslim+90 countries, possibly because the clients of Islamic banks in those countries are, on average, more concerned about their religious beliefs and hence are more risk averse than conventional banks' clients. We also find that the domestic interest rate coefficient is significant only in the Muslim-90 sub-sample (where the share of domestic credit provided by the banking system in GDP is $68 \%$ compared to $39 \%$ in Muslim+90 countries -implying sensitivity of loan risk to interest rates in more leveraged economies).

In Annex 5 columns (3) and (4), the interaction term of Islamic bank dummy variable and domestic interest rate (Islamic_Bank $\times$ Domestic_Interest_Rate) is added to the Muslim+90 and Muslim-90 sub-samples respectively. Using the Muslim-90 sub-sample, we find that credit risk of Islamic banks is less sensitive to interest rates compared to conventional banks. The results imply that loan takers from Islamic banks have, on average, lower income gearing (the ratio of interest payment to disposable income) so that they have lower sensitivity to interest rate changes $^{32}$. For the countries classified as the Muslim+90, no significant difference between Islamic and conventional banks in terms of interest rate sensitivity is observed.

We also observe a positive relationship between leverage and loan quality of Islamic banks. To disentangle the impact of greater market discipline associated with higher leverage, from clients' religiosity and investigate whether they cancel out each other, (as the religious beliefs of clients may induce greater loyalty and thus reduce deposit withdrawal risk) we split our

\footnotetext{
${ }^{31}$ The sample is sorted based on the Muslim population. Observations above the median are those with at least $90 \%$ Muslims in their population (Muslim+90) and the remainder is placed in another category ("Muslim-90"). Countries in the Muslim+90 category generally have legal systems primarily based on Sharia law, they have lower GDP per capita and growth rates, but higher domestic interest rates compared to countries in the Muslim-90. Table B of Annex 3 presents the macroeconomic and banking indicators for these two groups of countries.

${ }^{32}$ Higher risk aversion of more religious individuals and possibly limited access to the credit market due to religious restrictions can explain lower income gearing of loan takers of Islamic banks.
} 
sample in the two groups of countries into high and low leveraged banks ${ }^{33}$. The estimates are given in columns (5) to (8) in Annex 5. Interestingly, highly leveraged Islamic banks have less risky loans even in the Muslim-90 countries. The Islamic bank dummy coefficient is larger (in absolute value) for the Muslim+90 sub-sample. The Islamic bank dummy for lowly leveraged banks in the Muslim+90 countries is significantly negative only at the $10 \%$ level. These results suggest that although Islamic banks try to lower withdrawal risk of investment account depositors by paying market returns, leverage seems to discipline Islamic banks more effectively than their conventional counterparts.

The previously reported results also show a negative impact of size on the loan quality for Islamic banks. To further analyze size effects taking into account the impact of leverage, in columns (9) to (12), we estimate our model using the following four sub-samples: small and highly leveraged banks, small and lowly leveraged banks, large and highly leveraged banks, large and lowly leveraged banks ${ }^{34}$. The results show no significant difference between low leveraged Islamic banks and their conventional counterparts, irrespective of whether they are classified as large or small banks. For more highly leveraged banks, we find that credit risk of small and high leveraged bank are significantly lower than their conventional counterparts. For large and high leveraged banks, the coefficient on the Islamic bank dummy is significantly negative only at the

\footnotetext{
${ }^{33}$ We classify banks as high or low leveraged, based on the median value of Capital_Asset_Ratio in each of the two groups of countries.

${ }^{34}$ Banks with total assets less than one billion US\$ are classified as small. De Young, et al. (2004) claim that small and large banks operate differently - small banks generally deal with small companies, which are relatively opaque. Large banks, however, can benefit from economies of scale, standardized products and are more transaction (as opposed to relationship) based. They mostly analyze hard information obtained from transparent firms. Hence, empirical investigation of the sub-samples might show the possible impact of different customer relationships on the credit risk of Islamic versus conventional banks.
} 
$10 \%$ level, which implies an inverse relationship between size and the credit risk of Islamic banks ${ }^{35}$.

To investigate whether the credit risk feature of Islamic banks differs during the recent financial crisis, we estimate the model, using the two sub-periods: the pre-crisis period, i.e. 20032007, and the crisis period, i.e. $2008-2009^{36}$. The estimations are presented in columns (13) and (14) of Annex 5. In both periods, Islamic banks exhibit lower credit risk than conventional banks.

\subsubsection{Insolvency Risk}

We find little evidence that Islamic banks' stability is affected differently from conventional banks by the share of Muslim in population. For further investigation, we estimate the insolvency risk model using the sub-samples of Muslim+90 and Muslim-90 and report the results in columns (1) and (2) in Annex 6. We observe no significant difference between Islamic and conventional banks in any of the two sub-samples. The estimations also suggest a positive relationship between interest rate and insolvency risk only for Muslim+90 countries, possibly because domestic interest rates in these countries are, on average, higher than the other groups of countries.

In columns (3) and (4) of Annex 6, the Islamic bank dummy and domestic interest rate interaction term (Islamic_Bank $\times$ Domestic_Interest_Rate) is included in the model, using the Muslim+90 and Muslim-90 sub-samples. The results show no significant difference between Islamic and conventional banks in terms of sensitivity to interest rate changes.

\footnotetext{
${ }^{35}$ We use Impaired_Loans and Loan_Loss_Provision as the credit risk proxy in lieu of Loan_Loss_Reserve and find almost similar results.

${ }^{36}$ BIS (2010) identifies the pre-crisis period from January 2003 to June 2007 and the acute-crisis as July 2007 to March 2009. Since quarterly data are not available, we consider 2003-2007 and 2008-2009 as the pre-crisis and the crisis periods respectively.
} 
In order to compare the stability of small and large Islamic and conventional banks, we split the sample into small and large banks. Column (5) presents the estimations using the small banks sub-sample. The results show that small Islamic banks are more stable than similar sized conventional banks. The absolute value of the Zscore is on average, $1.47\left(1.47=e^{0.388}\right)$ higher for small Islamic banks than for similar-sized conventional banks, (or to put another way, is $4.67 \%\left(4.67=100 \times \frac{1.47}{e^{3.45}}\right)$ higher than the average Zscore of small conventional banks.) In columns (6) and (7), we replace the insolvency risk proxy with the logarithm of its first and second components respectively and find that the stability of small Islamic banks is due to their higher capitalization. In columns (8) to (10), we estimate the model using the large banks subsample, including the stability proxy and the logarithm of its first and second components. The estimations show no significant difference between large Islamic and conventional banks.

Column (11) presents the estimation for the pre-crisis period (2003-2007) and also shows no significant difference between Islamic and conventional banks. In column (12) we use the crisis period (2008-2009) sub-sample and find that Islamic banks are less stable than conventional banks ${ }^{37}$. In columns (13) and (14), we estimate the model for small and large bank sub-samples during the crisis period. The results show that only large Islamic banks are less stable than similar sized conventional banks, while no significant difference is observed between small banks.

\subsubsection{Bank (Implicit) Interest Rates}

In order to investigate whether our bank interest rate findings are robust across different specifications, we re-estimate the models reported in Table V, using the Muslim+90 / Muslim-90

\footnotetext{
${ }^{37}$ For the crisis period, we consider the Zscore calculated from 2006-2008 and 2007-2009 windows. We also estimate the model using the Zscore calculated based on 2007-2009 window and find qualitatively similar results.
} 
sub-samples and small / large banks sub-samples. The results (not reported here) support our previous finding that Islamic banks charge no special rent to their clients for offering Shariácompliant products. We also find that the positive relationship between domestic interest rates and net interest margin, implicit interest income and expense rates, and implicit interest rate on deposits holds for the Muslim+90 and large banks sub-samples. Our results also show that the lower sensitivity of implicit interest income and expense rates of Islamic banks compared to those of their conventional counterparts are in line with previous results, when we use the Muslim+90 and large bank sub-samples.

We also investigate these relationships before and during the recent financial crisis. The results are presented in Annex 7. In columns (1) to (5), we estimate the model for the pre-crisis period (2003-2007) and the estimations on the crisis period (2008-2009) are illustrated in columns (6) to (10). For the pre-crisis period, we find no significant difference between Islamic and conventional banks, except for the implicit interest rate on deposits, wherein Islamic banks exhibit lower sensitivity to interest rate changes than conventional banks.

In the crisis period, the results are different. We find higher sensitivity of Islamic banks' net interest margin to interest rate movements than for conventional banks. Columns (7) and (8) can explain this result. While the implicit interest income rate of Islamic banks is less sensitive to interest rate changes than for conventional banks, no significant difference is found for the implicit interest expense rate. Finally, both implicit interest rates on loans and deposits of Islamic banks exhibit lower sensitivity to interest rate changes, than those of conventional banks.

\subsubsection{Other Checks}

As further robustness checks we exclude banking systems that are entirely Islamic - Iran and Sudan - from the sample and re-estimate models (1) to (3), the results remain significantly 
unchanged $^{38}$. Turkey experienced particularly high levels of domestic interest rates especially at the beginning of the previous decade and this may have influenced our interest rate findings. We therefore estimate our three models excluding information on Turkey and re-examine the sensitivity of Islamic banks to interest rates. The results are mainly in-line with our previous findings ${ }^{39}$. However, here we do find that, for our Muslim+90 sub-sample, insolvency risk is higher for conventional banks at the five percent significance level. The absolute value of Zscore is on average $1.52\left(1.52=e^{0.420}\right)$ higher for Islamic than conventional banks, which is equivalent to $4.84 \%\left(4.84=100 \times \frac{1.52}{e^{3.448}}\right)$ of the average Zscore of conventional banks operating in Muslim+90 countries. However, contrary to our previous findings, no significant sensitivity of insolvency risk and net interest margin to domestic interest rates is observed. As a final robustness check, we estimate the model using the logarithm of the Zscore where return volatility is calculated over the whole period (for banks with at least four consecutive observations). On the right hand side of the Equation, we use the mean value of the explanatory variables over the sample period. This approach provides us with between group estimation and reduces noise although we have to use a cross-sectional (rather than panel) estimation approach. Similar to our previous findings, smaller Islamic banks exhibit lower insolvency risk than similar-sized conventional banks and we find no difference between larger banks.

\footnotetext{
${ }^{38}$ In response to the referee's comment we investigate whether the performance of conventional and Islamic banks are linked to the market share of Islamic banking in countries with dual banking systems. To do this we include Islamic bank assets market share (per country per year) into our three models and re-estimate our models using subsamples for Islamic and conventional banks. The results show that higher Islamic banks' assets market share is associated with more stable conventional banks (at the 1\% significance level) but less stability for Islamic banks (at the $10 \%$ level). This latter outcome is driven by the capital variable in the Zscore. We also find a negative correlation between the assets market share of Islamic banks and their Interest_Expense_Rate at the 5\% significance level. These results are available from the authors on request.

${ }^{39}$ Results are available from the authors upon request.
} 


\section{Summary and Conclusion}

This paper analyzes the risk and stability features of Islamic banks. The obligations of Islamic banks towards depositors (investment account holders) are different from those of conventional banks and hence they face different risks. Conventional banks have to fulfill their obligations towards depositors irrespective of their profits or losses whereas Islamic banks are supposed to share the realized profit or loss with investment account holders. This special relationship may discipline Islamic banks more effectively by imposing higher withdrawal risk. In practice, to avoid withdrawal risk, Islamic banks tend to partly deviate from the PLS principles of Islamic finance. They pay a relatively competitive rate of return to investment account holders, regardless of their realized performance. On the asset side, it appears that Islamic banks mainly apply non-PLS modes of Islamic finance which are in nature closer to conventional finance. Nevertheless, Islamic banks still may face extra risks because of the complexity of Islamic modes of finance and limitations in their funding, investment and risk management activities. On the other hand, customers of Islamic banks are expected to be more concerned about their religious beliefs. Taking into account the positive relationship between religiosity and an individual's risk aversion, Islamic banks may face less risk (credit risk) than conventional banks.

We attempt to investigate the credit risk and stability features of Islamic commercial banks using a sample of 553 conventional and Islamic banks from 24 countries between 1999 and 2009. This research also explores whether Islamic banks charge extra cost to their clients for offering Shariá compliant financial products. After controlling for various factors we find that Islamic banks have lower credit risk than conventional banks, and this is specifically the case for small highly leveraged banks, or operating in predominantly Muslim countries (those where Muslims exceed 90\% Muslims of the population). In terms of insolvency risk, small Islamic banks also appear to exhibit greater stability than conventional banks, as they are more 
capitalized; however, no significant difference between large Islamic and conventional banks is observed. Loan quality, (implicit) interest income and (implicit) interest expense of Islamic banks are less sensitive to domestic interest rates compared to conventional counterparts; however, the sensitivity of Islamic banks' solvency position to interest rates is not significantly different from that of their conventional counterparts. Finally, we find little evidence that Islamic banks charge rents to their customers for offering Shariá compliant financial products. The fact that Islamic banks do not appear to emulate the risk and stability characteristics of their conventional counterparts has implications for policymakers (in terms of whether there should be a different legislation for the two types of banks), regulators (should they be regulated differently) and market participants (can traditional risk management tools be used to gauge and control these risks?) 


\section{Annex 1. Variable Description}

This annex describes the variables used in this study.

\begin{tabular}{|c|c|}
\hline Credit Risk Proxies & Description \\
\hline Loan_Loss_Reserve & $\begin{array}{l}\text { The ratio of loan loss reserves to gross loans. Loan loss reserve is considered for the whole loans portfolio, and not only for impaired loans. The } \\
\text { managers assess the quality of the loans portfolio and determine the required reserves. Then the current level of Loan loss reserve will be adjusted to } \\
\text { reach the required level. The adjustment will be reflected in the loan loss provision stipulated in the income statement. When a bank decides to write } \\
\text { off a loan, the loan amount would be deducted from the Loan loss reserve. }\end{array}$ \\
\hline Impaired_Loans & $\begin{array}{l}\text { The ratio of impaired loans to gross loans. Impaired loans increase when a bank classifies a specific loan or a part of a loan portfolio as bad. It } \\
\text { decreases when either a bank re-assesses a problem loan or part of a portfolio or when a bank writes off a loan or a part of loan portfolio. }\end{array}$ \\
\hline Loan_Loss_Provision & $\begin{array}{l}\text { The ratio of loan loss provision to average gross loans. Loan loss provision is the incurred cost to banks of adjusting the loan loss reserve or writing off } \\
\text { a loan. Hence, Loan_Loss_Reserve and Impaired_Loans are stocks while Loan_Loss_Provision is a flow and is stipulated in the income statement. It is } \\
\text { possible to have a negative loan loss provision in one period, when the required loan loss reserve is lower than the current reserve. }\end{array}$ \\
\hline \multicolumn{2}{|l|}{ Insolvency Risk Proxies } \\
\hline Zscore_rw & $\begin{array}{l}\text { Logarithm of rolling-window Zscore which is equal to (ROAA+CAR)/SDROAA_rw, SDROAA_rw = Standard deviation of ROAA over } 3 \text { years } \\
\text { (current year and two previous consecutive years). Banks need to have three consecutive observations. Acquiring banks are excluded from the sample, } \\
\text { since the volatility on their assets returns can be due to the acquisition. }\end{array}$ \\
\hline Zscore_P1_rw & Logarithm of ROAA/SDROAA3_rw. \\
\hline Zscore_P2_rw & Logarithm of Capital_Asset_Ratio/SDROAA3_rw. \\
\hline Zscore & $\begin{array}{l}\text { Logarithm of (M_ROAA+M_Capital_Asset_Ratio)/SDROAA, M_ROAA }=\text { Mean of ROAA over the sample period, M_Capital_Asset_Ratio =Mean } \\
\text { of Capital_Asset_Ratio over the sample period, SDROAA= standard deviation of ROAA over the sample period (banks needs to have at least four } \\
\text { consecutive observations). }\end{array}$ \\
\hline Zscore_Pl & Logarithm of M_ROAA/SDROAA. \\
\hline Zscore_P2 & Logarithm of M_ETA/SDROAA. \\
\hline \multicolumn{2}{|l|}{ Bank Interest Rate Proxies } \\
\hline Net_Interest_Margin & (Interest Income - Interest Expense) / Average Earning assets. \\
\hline Interest_Income_Rate & Interest income divided by average earning assets for conventional banks and mark-up income over average earning assets for Islamic banks. \\
\hline Interest_Expense_Rate & Interest expense divided by average interest bearing liabilities and profit payouts over average profit bearing liabilities for Islamic banks. \\
\hline Loan_Rate & $\begin{array}{l}\text { Interest income on loans divided by average gross lending for conventional banks and mark-up income on lending divided by average gross loans for } \\
\text { Islamic banks. }\end{array}$ \\
\hline Deposit_Rate & $\begin{array}{l}\text { Interest expense on customer deposit divided by average customer deposits for conventional banks and profit payouts on customer deposits divided by } \\
\text { average customer deposits for Islamic banks. }\end{array}$ \\
\hline \multicolumn{2}{|l|}{ Financial Ratio } \\
\hline Size & Logarithm of total assets. \\
\hline Market_Share & Logarithm of market share of total assets. \\
\hline Capital_Asset_Ratio & Equity capital to asset ratio. \\
\hline Loan_Total_Earning_Asset_Ratio & Share of net loans in total earning assets. \\
\hline Loan_Growth & Annual growth rate of gross loans. \\
\hline Asset_Growth & Annual growth rate of total assets. \\
\hline Noninterest_Income & Share of non-interest income in total operating income. \\
\hline Cost_Inefficiency & Cost to income ratio. \\
\hline \multicolumn{2}{|l|}{ Ownership Structure } \\
\hline State_Bank & State-owned bank dummy that takes the value of one if the bank is state-owned, and zero otherwise. \\
\hline Foreign_Bank & Foreign-owned bank dummy that takes the value of one if the bank is Foreign-owned, and zero otherwise. \\
\hline Subsidiary & Subsidiary dummy that takes the value of one if the bank is subsidiary, and zero otherwise. \\
\hline \multicolumn{2}{|l|}{ Banks Age or Experience Level } \\
\hline Young_ Bank & Young bank dummy that takes the value of one, if the bank has been operating for at most three years, and zero otherwise. \\
\hline Middle-Aged_Bank & Middle-aged bank dummy that takes the value of one if the bank has operated from three to seven years, and zero otherwise. \\
\hline \multicolumn{2}{|l|}{ Country Level Variables } \\
\hline Muslim_Share & Share of the Muslim population in the total population of each country. \\
\hline Legal_System & $\begin{array}{l}\text { Takes the value of zero, if the country does not use Shariá law to define its legal system, the value one for countries which consider Shariá together } \\
\text { with other legal systems, and has the value two if the legal system is based exclusively on Shariá law. }\end{array}$ \\
\hline Domestic_Interest_Rate & $\begin{array}{l}\text { Deposit Interest Rate provided by the World Bank website; for years and countries with missing observations, the data is obtained from the central } \\
\text { bank web-sites. }\end{array}$ \\
\hline$H H I$ & $\begin{array}{l}\text { Hirschman-Herfindahl index (HHI) is a proxy for market concentration: } H_{H I} I_{c, t}=\sum_{i=1}^{n}\left(\text { Total_Assets }_{i, t, c} / \sum_{i=1}^{n} \text { Total_Assets }_{i, t, c}\right)^{2} \text {. It has a value } \\
\text { between zero and one. Higher values show that the market is more concentrated. }\end{array}$ \\
\hline GDP_Per_Capita & GDP per capita in US\$. \\
\hline GDP_Per_Capita_Growth & Annual growth rate of GDP per capita. \\
\hline
\end{tabular}


Annex 2.

Table A. Islamic, Conventional and Islamic Window Banks Distributions across Countries

This table presents the number of Islamic, conventional and Islamic window banks across 24 countries, over the 1999-2009 period.

\begin{tabular}{|c|c|c|c|c|c|c|c|c|}
\hline \multirow{2}{*}{ Country } & \multicolumn{2}{|c|}{ Islamic bank } & \multicolumn{2}{|c|}{ Islamic Window Bank } & \multicolumn{2}{|c|}{ Conventional Bank } & \multicolumn{2}{|c|}{ Total } \\
\hline & Banks & Observations & Banks & Observations & Banks & Observations & Banks & Observations \\
\hline Algeria & 3 & 19 & 1 & 9 & 11 & 73 & 15 & 101 \\
\hline Bahrain & 6 & 44 & 6 & 47 & 1 & 8 & 13 & 99 \\
\hline Bangladesh & 5 & 42 & 9 & 71 & 19 & 175 & 33 & 288 \\
\hline Brunei & 4 & 19 & 0 & 0 & 1 & 8 & 5 & 27 \\
\hline Egypt & 3 & 20 & 6 & 57 & 25 & 183 & 34 & 260 \\
\hline Gambia & 1 & 4 & 0 & 0 & 7 & 38 & 8 & 42 \\
\hline Indonesia & 2 & 21 & 12 & 73 & 70 & 472 & 84 & 566 \\
\hline Iran & 12 & 95 & 0 & 0 & 0 & 0 & 12 & 95 \\
\hline Iraq & 4 & 13 & 0 & 0 & 8 & 42 & 12 & 55 \\
\hline Jordan & 3 & 21 & 0 & 0 & 10 & 97 & 13 & 118 \\
\hline Kuwait & 3 & 21 & 1 & 5 & 5 & 46 & 9 & 72 \\
\hline Lebanon & 1 & 7 & 3 & 23 & 49 & 334 & 53 & 364 \\
\hline Malaysia & 17 & 92 & 12 & 104 & 24 & 123 & 53 & 319 \\
\hline Mauritania & 1 & 9 & 3 & 21 & 5 & 36 & 9 & 66 \\
\hline Pakistan & 6 & 26 & 12 & 105 & 14 & 84 & 32 & 215 \\
\hline Qatar & 4 & 34 & 3 & 17 & 3 & 34 & 10 & 85 \\
\hline Saudi Arabia & 3 & 28 & 7 & 72 & 0 & 0 & 10 & 100 \\
\hline Senegal & 1 & 6 & 0 & 0 & 12 & 88 & 13 & 94 \\
\hline Sudan & 20 & 135 & 0 & 0 & 2 & 7 & 22 & 142 \\
\hline Syria & 2 & 5 & 0 & 0 & 11 & 61 & 13 & 66 \\
\hline Tunisia & 1 & 10 & 1 & 9 & 13 & 90 & 15 & 109 \\
\hline Turkey & 4 & 15 & 0 & 0 & 42 & 246 & 46 & 261 \\
\hline UAE & 8 & 62 & 5 & 27 & 16 & 153 & 29 & 242 \\
\hline Yemen & 4 & 34 & 0 & 0 & 6 & 50 & 10 & 84 \\
\hline Total & 118 & 782 & 81 & 640 & 354 & 2448 & 553 & 3870 \\
\hline
\end{tabular}

Table B. Ownership Structure and Age of Banks

This table presents the ownership structure and age (experience level) of Islamic, conventional and Islamic window banks

\begin{tabular}{|c|c|c|c|c|c|c|c|c|}
\hline & \multicolumn{2}{|c|}{ Islamic bank } & \multicolumn{2}{|c|}{ Islamic Window Bank } & \multicolumn{2}{|c|}{ Conventional Bank } & \multicolumn{2}{|r|}{ Total } \\
\hline & Banks & Observations & Banks & Observations & Banks & Observations & Banks & Observations \\
\hline State-owned Banks & 16 & 125 & 8 & 59 & 38 & 316 & 62 & 500 \\
\hline Foreign-owned Banks & 26 & 165 & 5 & 39 & 32 & 198 & 63 & 402 \\
\hline Subsidiaries & 14 & 73 & 15 & 87 & 99 & 624 & 128 & 784 \\
\hline Private-owned Banks & 62 & 419 & 53 & 455 & 185 & 1310 & 300 & 2184 \\
\hline Total & 118 & 782 & 81 & 640 & 354 & 2448 & 553 & 3870 \\
\hline Young Banks & 47 & 115 & 11 & 28 & 51 & 118 & 109 & 261 \\
\hline Middle-Aged Banks & 13 & 142 & 9 & 40 & 37 & 220 & 59 & 402 \\
\hline Matured Banks & 58 & 525 & 61 & 572 & 266 & 2110 & 385 & 3207 \\
\hline Total & 118 & 782 & 81 & 640 & 354 & 2448 & 553 & 3870 \\
\hline
\end{tabular}


Annex 3.

Table A. Macroeconomic and Banking Indicators across Countries

This table presents the mean value of macroeconomic and banking indicators across 24 countries, over the 1999-2009 period.

\begin{tabular}{|c|c|c|c|c|c|c|c|c|}
\hline Countries & $\begin{array}{c}\text { Muslim_Share } \\
(\%)\end{array}$ & Legal_System & $\begin{array}{c}\text { Domestic_Interest_Rate } \\
(\%)\end{array}$ & HHI & $\begin{array}{c}\text { GDP_Per_Capita } \\
(\$)\end{array}$ & $\begin{array}{c}\text { GDP_Per_Capita_Growth } \\
(\%)\end{array}$ & $\begin{array}{c}\text { Domestic_Credit } \\
(\%)\end{array}$ & Explicit_Deposit_Insurance \\
\hline Algeria & 98 & 1 & 4.1 & 0.26 & 6,796 & 2.1 & 17 & 1 \\
\hline Bahrain & 81 & 1 & 3.0 & 0.26 & 27,275 & 3.7 & 51 & 1 \\
\hline Bangladesh & 89.6 & 0 & 8.5 & 0.16 & 1,047 & 4.0 & 51 & 1 \\
\hline Brunei & 67.2 & 1 & 1.9 & 0.64 & 47,490 & -0.5 & 26 & 0 \\
\hline Egypt & 94.6 & 1 & 7.8 & 0.18 & 4,383 & 3.3 & 92 & 0 \\
\hline Gambia & 95 & 1 & 14.5 & 0.41 & 1,156 & 1.0 & 25 & 0 \\
\hline Indonesia & 88.2 & 0 & 12.0 & 0.11 & 3,152 & 3.4 & 48 & 1 \\
\hline Iran & 99.4 & 2 & 12.6 & 0.30 & 9,024 & 3.3 & 37 & 0 \\
\hline Iraq & 99 & 1 & 7.5 & 0.57 & 3,396 & 0.3 & 0 & 0 \\
\hline Jordan & 98.2 & 1 & 5.0 & 0.51 & 4,227 & 3.5 & 94 & 1 \\
\hline Kuwait & 95 & 1 & 4.2 & 0.38 & 39,922 & 2.3 & 74 & 0 \\
\hline Lebanon & 59.3 & 0 & 9.2 & 0.17 & 9,558 & 2.9 & 176 & 1 \\
\hline Malaysia & 60.4 & 0 & 3.2 & 0.10 & 11,393 & 2.9 & 132 & 1 \\
\hline Mauritania & 99.1 & 1 & 8.2 & 0.36 & 1,679 & 1.4 & -3 & 0 \\
\hline Pakistan & 96.3 & 1 & 4.8 & 0.17 & 2,114 & 2.2 & 44 & 0 \\
\hline Qatar & 77.5 & 1 & 3.6 & 0.38 & 67,840 & 3.5 & 53 & 0 \\
\hline Saudi Arabia & 97 & 2 & 4.0 & 0.26 & 20,451 & 0.7 & 28 & 0 \\
\hline Senegal & 96 & 0 & 3.5 & 0.19 & 1,558 & 1.5 & 23 & 0 \\
\hline Sudan & 71.3 & 1 & 13.1 & 0.18 & 1,633 & 3.9 & 13 & 1 \\
\hline Syria & 92.2 & 0 & 6.2 & 0.46 & 3,974 & 1.2 & 33 & 0 \\
\hline Tunisia & 99.5 & 1 & 3.4 & 0.30 & 6,309 & 3.7 & 72 & 0 \\
\hline Turkey & 98 & 0 & 38.0 & 0.11 & 10,332 & 1.7 & 47 & 1 \\
\hline UAE & 76.2 & 1 & 3.3 & 0.14 & 47,863 & 1.3 & 62 & 0 \\
\hline Yemen & 99.1 & 1 & 13.4 & 0.19 & 2,148 & 0.9 & 9 & 0 \\
\hline
\end{tabular}

Muslim Share $=$ Share of the Muslim population in the total population of each country, Legal System = Takes the value of zero, if the country does not use Shariá law to define its legal system, the value one for countries which consider Shariá together with other legal systems, and has the value two if the legal system is based exclusively on Shariá law, Domestic_Interest_Rate $=$ Deposit Interest Rate provided by the World Bank website, HHI $=$ Hirschman-Herfindahl index which is a proxy for market concentration, GDP_Per_Capita $=$ GDP per capita in US\$, GDP_Per_Capita_Growth = Annual growth rate of GDP per capita, Domestic_Credit $=$ Domestic credit provided by banking system as the percentage of GDP, Explicit_Deposit_Insurance $=$ Explicit Deposit Insurance Scheme Dummy, that takes the value of one for countries with explicit deposit insurance scheme and takes zero otherwise.

Table B. Macroeconomic and Banking Indicators across Two Groups of Countries

This table presents the mean value of macroeconomic and banking system indicators across two groups of countries (Muslim+90 \& Muslim-90), over the 1999-2009 period.

\begin{tabular}{cccccc}
\hline & Domestic_Interest_Rate (\%) & HHI & GDP_Per_Capita (\$) & GDP_Per_Capita_Growth (\%) & Domestic_Credit (\%) \\
\hline Muslim+90 & 9.1 & 0.31 & 7,831 & 39 \\
Muslim-90 & 6.4 & 0.24 & 24,139 & 2.9 & 2.8 \\
\hline
\end{tabular}

Muslim $+90=$ Covers the countries with at least $90 \%$ of Muslims in their population, Muslim-90 = Covers the countries with less than $90 \%$ of Muslims in their population. Domestic_Interest_Rate $=$ Deposit Interest Rate provided by the World Bank website, HHI = Hirschman-Herfindahl index which is a proxy for market concentration, GDP_Per_Capita = GDP per capita in US\$, GDP_Per_Capita_Growth = Annual growth rate of GDP per capita, Domestic_Credit = Domestic credit provided by banking system as the percentage of GDP. 
Annex 4. Correlation Matrix

This table presents the pair-wise correlation between the variables used in our analysis.

\begin{tabular}{|c|c|c|c|c|c|c|c|c|c|c|c|c|c|c|c|c|c|c|c|c|c|c|c|c|c|c|c|c|c|c|}
\hline & 1 & 2 & 3 & 4 & 5 & 6 & 7 & 8 & 9 & 10 & 11 & 12 & 13 & 14 & 15 & 16 & 17 & 18 & 19 & 20 & 21 & 22 & 23 & 24 & 25 & 26 & 27 & 28 & 29 & 30 \\
\hline (1) Loan_Loss_Reserve & 1.00 & & & & & & & & & & & & & & & & & & & & & & & & & & & & & \\
\hline (2) Impaired_Loans & 0.79 & 1.00 & & & & & & & & & & & & & & & & & & & & & & & & & & & & \\
\hline (3) Loan_Loss_Provision & 0.26 & 0.26 & 1.00 & & & & & & & & & & & & & & & & & & & & & & & & & & & \\
\hline (4) Zscore_rw & -0.08 & -0.13 & -0.07 & 1.00 & & & & & & & & & & & & & & & & & & & & & & & & & & \\
\hline (5) Net_Interest_Margin & -0.09 & -0.13 & 0.06 & -0.08 & 1.00 & & & & & & & & & & & & & & & & & & & & & & & & & \\
\hline (6) Interest_Income_Rate & -0.01 & -0.01 & 0.02 & -0.13 & 0.60 & 1.00 & & & & & & & & & & & & & & & & & & & & & & & & \\
\hline (7) Interest_Expense_Rate & 0.01 & 0.05 & -0.01 & -0.12 & 0.09 & 0.73 & 1.00 & & & & & & & & & & & & & & & & & & & & & & & \\
\hline (8) Loan_Rate & -0.05 & -0.13 & 0.01 & -0.08 & 0.55 & 0.80 & 0.65 & 1.00 & & & & & & & & & & & & & & & & & & & & & & \\
\hline (9) Deposit_Rate & -0.02 & -0.05 & 0.01 & -0.12 & 0.09 & 0.70 & 0.89 & 0.65 & 1.00 & & & & & & & & & & & & & & & & & & & & & \\
\hline (10) Islamic_Bank & -0.08 & -0.08 & -0.04 & -0.03 & 0.02 & -0.12 & -0.12 & -0.01 & 0.04 & 1.00 & & & & & & & & & & & & & & & & & & & & \\
\hline (11) Islamic_Window_Bank & -0.02 & -0.01 & 0.00 & 0.03 & -0.09 & -0.11 & -0.10 & -0.09 & -0.07 & -0.22 & 1.00 & & & & & & & & & & & & & & & & & & & \\
\hline (12) Size & -0.17 & -0.21 & -0.08 & 0.01 & -0.12 & -0.09 & -0.02 & -0.02 & 0.10 & -0.04 & 0.12 & 1.00 & & & & & & & & & & & & & & & & & & \\
\hline (13) Market_Share & -0.10 & -0.13 & 0.01 & 0.00 & -0.07 & -0.16 & -0.16 & -0.09 & -0.04 & 0.04 & 0.07 & 0.72 & 1.00 & & & & & & & & & & & & & & & & & \\
\hline (14) Capital_Asset_Ratio & 0.05 & 0.01 & 0.00 & 0.17 & 0.14 & -0.03 & -0.12 & 0.00 & -0.10 & 0.13 & -0.08 & -0.34 & -0.37 & 1.00 & & & & & & & & & & & & & & & & \\
\hline (15) Loan_Total_Eaming_Asset_Ratio & -0.30 & -0.23 & -0.02 & 0.07 & -0.01 & -0.06 & -0.09 & 0.10 & 0.11 & 0.06 & 0.04 & 0.08 & 0.06 & -0.09 & 1.00 & & & & & & & & & & & & & & & \\
\hline (16) Loan_Growth & -0.27 & -0.33 & -0.03 & -0.01 & 0.11 & 0.05 & 0.00 & 0.06 & 0.00 & 0.08 & -0.03 & -0.06 & -0.04 & 0.00 & 0.17 & 1.00 & & & & & & & & & & & & & & \\
\hline (17) Asset_Growth & -0.20 & -0.24 & -0.03 & -0.01 & 0.05 & 0.05 & 0.03 & 0.04 & 0.04 & 0.10 & -0.03 & -0.05 & -0.06 & -0.01 & 0.04 & 0.60 & 1.00 & & & & & & & & & & & & & \\
\hline (18) Noninterest_Income & 0.05 & 0.06 & 0.05 & -0.07 & -0.42 & -0.28 & -0.09 & -0.14 & -0.04 & 0.14 & -0.04 & -0.06 & 0.10 & -0.01 & 0.06 & -0.01 & -0.02 & 1.00 & & & & & & & & & & & & \\
\hline (19) Cost_Inefficiency & 0.05 & 0.17 & -0.02 & -0.15 & -0.10 & 0.10 & 0.21 & 0.13 & 0.18 & 0.06 & -0.12 & -0.11 & -0.06 & -0.09 & -0.01 & 0.01 & 0.00 & 0.09 & 1.00 & & & & & & & & & & & \\
\hline (20) State_Bank & 0.01 & -0.03 & 0.00 & 0.01 & -0.08 & -0.05 & 0.00 & -0.05 & 0.00 & 0.06 & -0.04 & 0.11 & 0.16 & -0.07 & 0.04 & -0.01 & -0.02 & 0.08 & -0.02 & 1.00 & & & & & & & & & & \\
\hline (21) Foreign_Bank & 0.05 & 0.06 & 0.02 & -0.02 & -0.05 & -0.06 & -0.03 & -0.10 & -0.02 & 0.15 & -0.05 & -0.11 & -0.09 & 0.03 & -0.02 & -0.01 & 0.01 & 0.06 & 0.06 & -0.13 & 1.00 & & & & & & & & & \\
\hline (22) Subsidiary & -0.01 & 0.01 & -0.02 & -0.06 & 0.08 & -0.04 & -0.13 & 0.03 & -0.14 & -0.14 & -0.05 & -0.03 & -0.07 & 0.04 & -0.03 & -0.05 & -0.05 & 0.00 & 0.01 & -0.19 & -0.18 & 1.00 & & & & & & & & \\
\hline (23) Young_Bank & -0.03 & -0.03 & -0.02 & -0.07 & 0.02 & -0.03 & -0.04 & 0.05 & -0.05 & 0.16 & -0.03 & -0.17 & -0.09 & 0.13 & -0.07 & 0.15 & 0.15 & 0.05 & 0.09 & -0.08 & -0.03 & 0.06 & 1.00 & & & & & & & \\
\hline (24) Middle_Aged_Bank & 0.01 & -0.01 & 0.02 & -0.04 & 0.04 & 0.03 & 0.01 & 0.08 & -0.02 & 0.12 & -0.04 & -0.08 & -0.02 & 0.04 & -0.04 & -0.01 & 0.02 & 0.04 & 0.01 & -0.06 & -0.01 & 0.05 & -0.10 & 1.00 & & & & & & \\
\hline (25) Muslim_Share & -0.03 & -0.06 & 0.04 & -0.16 & 0.14 & 0.12 & 0.13 & 0.31 & 0.21 & -0.06 & -0.01 & 0.00 & 0.13 & 0.01 & 0.09 & 0.05 & 0.01 & 0.09 & 0.04 & 0.10 & 0.04 & -0.03 & 0.06 & 0.04 & 1.00 & & & & & \\
\hline (26) Legal_System & 0.05 & -0.02 & 0.05 & -0.01 & -0.07 & -0.30 & -0.30 & -0.19 & -0.13 & 0.34 & 0.10 & 0.05 & 0.26 & 0.09 & 0.03 & 0.03 & 0.03 & 0.15 & -0.10 & 0.20 & 0.06 & -0.12 & 0.08 & 0.02 & 0.38 & 1.00 & & & & \\
\hline (27) Domestic_Interest_Rate & 0.00 & 0.02 & 0.06 & -0.23 & 0.37 & 0.70 & 0.66 & 0.58 & 0.67 & -0.09 & -0.16 & -0.01 & -0.08 & -0.02 & -0.13 & -0.01 & -0.02 & -0.15 & 0.19 & -0.02 & -0.03 & -0.01 & -0.07 & -0.03 & 0.22 & -0.26 & 1.00 & & & \\
\hline (28) HHI & 0.01 & 0.01 & 0.03 & 0.02 & -0.04 & -0.21 & -0.24 & -0.24 & -0.20 & 0.14 & -0.05 & -0.05 & 0.23 & 0.10 & 0.03 & 0.02 & 0.04 & 0.10 & -0.10 & 0.08 & 0.00 & -0.10 & 0.11 & 0.02 & 0.25 & 0.44 & -0.18 & 1.00 & & \\
\hline (29) GDP_Per_Capita & -0.04 & -0.08 & -0.03 & 0.10 & -0.08 & -0.26 & -0.25 & -0.25 & -0.20 & 0.13 & 0.05 & 0.15 & 0.09 & 0.15 & 0.01 & -0.01 & 0.00 & -0.11 & -0.24 & 0.07 & -0.13 & -0.10 & 0.02 & -0.03 & -0.25 & 0.28 & -0.18 & 0.18 & 1.00 & \\
\hline (30) GDP_Per_Capita_Growth & -0.10 & -0.12 & -0.03 & 0.02 & -0.05 & -0.07 & -0.10 & 0.02 & 0.13 & 0.03 & 0.01 & 0.00 & -0.07 & 0.04 & 0.10 & 0.11 & 0.10 & 0.09 & -0.02 & -0.04 & 0.01 & -0.01 & 0.03 & 0.00 & -0.02 & -0.04 & -0.19 & -0.05 & -0.04 & 1.00 \\
\hline
\end{tabular}


Annex 5. Credit Risk Model

This table presents the estimation of credit risk model, using different sub-samples: Muslim+90/Muslim-90, low/high leveraged banks, small/large banks and pre-crisis/the crisis periods.

\begin{tabular}{|c|c|c|c|c|c|c|c|c|c|c|c|c|c|c|}
\hline \multirow[b]{3}{*}{ Variables } & \multirow{3}{*}{$\frac{(1)}{\text { Muslim+90 }}$} & \multirow{3}{*}{$\begin{array}{c}\text { (2) } \\
\text { Muslim-90 }\end{array}$} & \multirow{3}{*}{$\frac{\text { (3) }}{\text { Muslim+90 }}$} & \multirow{3}{*}{$\begin{array}{c}\text { (4) } \\
\text { Muslim-90 }\end{array}$} & \multirow{2}{*}{\multicolumn{2}{|c|}{ (D) }} & (7) & (8) & (9) & (10) & (11) & (12) & (13) & (14) \\
\hline & & & & & & & \multicolumn{2}{|c|}{ Muslim-90 } & \multicolumn{2}{|c|}{ Small Banks } & \multicolumn{2}{|c|}{ Large Banks } & \multirow{2}{*}{$\begin{array}{l}\text { Pre-Crisis } \\
\text { Period }\end{array}$} & \multirow{2}{*}{$\begin{array}{l}\text { Crisis } \\
\text { Period }\end{array}$} \\
\hline & & & & & $\begin{array}{c}\text { Highly } \\
\text { Leveraged }\end{array}$ & $\begin{array}{c}\text { Lowly } \\
\text { Leveraged }\end{array}$ & $\begin{array}{c}\text { Highly } \\
\text { Leveraged }\end{array}$ & $\begin{array}{c}\text { Lowly } \\
\text { Leveraged }\end{array}$ & $\begin{array}{c}\text { Highly } \\
\text { Leveraged }\end{array}$ & $\begin{array}{c}\text { Lowly } \\
\text { Leveraged }\end{array}$ & $\begin{array}{c}\text { Highly } \\
\text { Leveraged }\end{array}$ & $\begin{array}{c}\text { Lowly } \\
\text { Leveraged }\end{array}$ & & \\
\hline Islamic_Bank $\left(\alpha_{1}\right)$ & $\begin{array}{c}-6.364 * * * * \\
(-3.44)\end{array}$ & $\begin{array}{r}-1.080 \\
(-0.83)\end{array}$ & $\begin{array}{l}-4.658 \\
(-1.38)\end{array}$ & $\begin{array}{l}0.773 \\
(0.47)\end{array}$ & $\begin{array}{c}-10.112 * * * * \\
(-3.89)\end{array}$ & $\begin{array}{c}-3.796^{*} \\
(-1.67)\end{array}$ & $\begin{array}{c}-2.947 * * \\
(-2.11)\end{array}$ & $\begin{array}{l}-1.186 \\
(-0.55)\end{array}$ & $\begin{array}{c}-7.564 * * \\
(-2.52)\end{array}$ & $\begin{array}{l}-2.698 \\
(-0.91)\end{array}$ & $\begin{array}{l}-2.137 * \\
(-1.81)\end{array}$ & $\begin{array}{l}-0.626 \\
(-0.41)\end{array}$ & $\begin{array}{c}-4.731 \text { **** } \\
(-3.82)\end{array}$ & $\begin{array}{c}-4.077 * * \\
(-2.08)\end{array}$ \\
\hline Islamic_Window_Bank $\left(\alpha_{2}\right)$ & $\begin{array}{l}-1.649 \\
(-0.98)\end{array}$ & $\begin{array}{l}-0.719 \\
(-0.72)\end{array}$ & $\begin{array}{l}-1.469 \\
(-0.86)\end{array}$ & $\begin{array}{l}-0.590 \\
(-0.59)\end{array}$ & $\begin{array}{l}-1.159 \\
(-0.63)\end{array}$ & $\begin{array}{l}-3.340 \\
(-1.24)\end{array}$ & $\begin{array}{l}-1.159 \\
(-0.91)\end{array}$ & $\begin{array}{l}-0.265 \\
(-0.14)\end{array}$ & $\begin{array}{l}-0.543 \\
(-0.32)\end{array}$ & $\begin{array}{l}-0.673 \\
(-0.26)\end{array}$ & $\begin{array}{l}-0.488 \\
(-0.40)\end{array}$ & $\begin{array}{l}-1.428 \\
(-0.71)\end{array}$ & $\begin{array}{l}-1.147 \\
(-0.95)\end{array}$ & $\begin{array}{l}-1.070 \\
(-0.55)\end{array}$ \\
\hline Size $\left(a_{3}\right)$ & $\begin{array}{c}-1.606 * * * * \\
(-2.82)\end{array}$ & $\begin{array}{l}-0.285 \\
(-0.79)\end{array}$ & $\begin{array}{c}-1.608 * * * \\
(-2.83)\end{array}$ & $\begin{array}{l}-0.362 \\
(-0.97)\end{array}$ & $\begin{array}{r}-1.415 \\
(-1.62)\end{array}$ & $\begin{array}{r}-1.419 \\
(-1.62)\end{array}$ & $\begin{array}{l}-0.018 \\
(-0.06)\end{array}$ & $\begin{array}{r}-0.410 \\
(-0.68)\end{array}$ & $\begin{array}{r}-0.343 \\
(-0.64)\end{array}$ & $\begin{array}{c}-1.028 * * * \\
(-2.50)\end{array}$ & $\begin{array}{l}-0.227 \\
(-0.56)\end{array}$ & $\begin{array}{r}-0.325 \\
(-0.91)\end{array}$ & $\begin{array}{l}-0.495 \\
(-1.56)\end{array}$ & $\begin{array}{l}-0.849 \\
(-0.88)\end{array}$ \\
\hline Market_Share $\left(\alpha_{4}\right)$ & $\begin{array}{l}0.213 \\
(0.29)\end{array}$ & $\begin{array}{l}-0.496 \\
(-0.61)\end{array}$ & $\begin{array}{l}0.209 \\
(0.29)\end{array}$ & $\begin{array}{l}-0.190 \\
(-0.22)\end{array}$ & $\begin{array}{l}-0.319 \\
(-0.15)\end{array}$ & $\begin{array}{l}0.072 \\
(0.09)\end{array}$ & $\begin{array}{l}-0.602 \\
(-1.09)\end{array}$ & $\begin{array}{l}-1.485 \\
(-1.21)\end{array}$ & $\begin{array}{l}-0.834 \\
(-0.60)\end{array}$ & $\begin{array}{c}-0.190 \\
(-0.41)\end{array}$ & $\begin{array}{c}-1.450^{* *} \\
(-2.06)\end{array}$ & $\begin{array}{l}0.163 \\
(0.23)\end{array}$ & $\begin{array}{c}-1.082^{* *} * \\
(-2.02)\end{array}$ & $\begin{array}{l}-1.009 \\
(-0.29)\end{array}$ \\
\hline Capital_Asset_Ratio $\left(\alpha_{5}\right)$ & $\begin{array}{l}-0.081 \\
(-1.02)\end{array}$ & $\begin{array}{l}0.001 \\
(0.03)\end{array}$ & $\begin{array}{l}-0.082 \\
(-1.04)\end{array}$ & $\begin{array}{l}0.001 \\
(0.02)\end{array}$ & $\begin{array}{c}-0.062 \\
(-0.38)\end{array}$ & $\begin{array}{l}-0.088 \\
(-1.61)\end{array}$ & $\begin{array}{l}-0.050 \\
(-1.39)\end{array}$ & $\begin{array}{l}-0.083 \\
(-1.17)\end{array}$ & $\begin{array}{c}-0.446^{*} \\
(-1.70)\end{array}$ & $\begin{array}{c}-0.092 * * * * \\
(-3.04)\end{array}$ & $\begin{array}{l}-0.054 \\
(-1.17)\end{array}$ & $\begin{array}{l}-0.130 \\
(-1.63)\end{array}$ & $\begin{array}{l}-0.046 \\
(-1.01)\end{array}$ & $\begin{array}{l}-0.051 \\
(-0.84)\end{array}$ \\
\hline Loan_Growth $\left(\alpha_{6}\right)$ & $\begin{array}{c}-0.032 * * * \\
(-3.11)\end{array}$ & $\begin{array}{c}-0.024 * * * \\
(-3.92)\end{array}$ & $\begin{array}{c}-0.032 * * * \\
(-3.09)\end{array}$ & $\begin{array}{c}-0.024 * * * * \\
(-3.91)\end{array}$ & $\begin{array}{c}-0.035 * * * * \\
(-2.80)\end{array}$ & $\begin{array}{l}-0.022 * \\
(-1.92)\end{array}$ & $\begin{array}{c}-0.017 * * \\
(-3.16)\end{array}$ & $\begin{array}{c}-0.024 * * * * \\
(-3.58)\end{array}$ & $\begin{array}{c}-0.027 * * * \\
(-2.26)\end{array}$ & $\begin{array}{c}-0.023 * * * \\
(-4.40)\end{array}$ & $\begin{array}{c}-0.018 * * * \\
(-2.01)\end{array}$ & $\begin{array}{l}-0.011 \\
(-0.85)\end{array}$ & $\begin{array}{c}-0.019 * * * \\
(-2.31)\end{array}$ & $\begin{array}{l}-0.009 \\
(-1.07)\end{array}$ \\
\hline Noninterest_Income $\left(\alpha_{7}\right)$ & $\begin{array}{l}0.002 \\
(0.12)\end{array}$ & $\begin{array}{r}-0.026 \\
(-1.44)\end{array}$ & $\begin{array}{l}0.003 \\
(0.15)\end{array}$ & $\begin{array}{l}-0.026 \\
(-1.40)\end{array}$ & $\begin{array}{l}0.028 \\
(0.86)\end{array}$ & $\begin{array}{l}0.001 \\
(0.04)\end{array}$ & $\begin{array}{l}-0.010 \\
(-0.54)\end{array}$ & $\begin{array}{l}-0.012 \\
(-0.57)\end{array}$ & $\begin{array}{l}0.015 \\
(0.71)\end{array}$ & $\begin{array}{l}-0.020 \\
(-1.03)\end{array}$ & $\begin{array}{l}0.015 \\
(0.96)\end{array}$ & $\begin{array}{l}-0.021 \\
(-1.03)\end{array}$ & $\begin{array}{l}0.007 \\
(0.30)\end{array}$ & $\begin{array}{l}-0.020 \\
(-0.84)\end{array}$ \\
\hline Cost_Inefficiency $\left(\alpha_{8}\right)$ & $\begin{array}{c}0.034 * * * \\
(2.43)\end{array}$ & $\begin{array}{l}-0.008 \\
(-0.83)\end{array}$ & $\begin{array}{c}0.034 * * * \\
(2.44)\end{array}$ & $\begin{array}{l}-0.006 \\
(-0.59)\end{array}$ & $\begin{array}{l}0.025 * \\
(1.77)\end{array}$ & $\begin{array}{l}0.023 \\
(1.49)\end{array}$ & $\begin{array}{l}0.013 \\
(1.38)\end{array}$ & $\begin{array}{c}-0.023 * \\
(-1.78)\end{array}$ & $\begin{array}{l}0.005 \\
(0.38)\end{array}$ & $\begin{array}{c}-0.030 * * \\
(-2.07)\end{array}$ & $\begin{array}{l}0.023 \\
(1.63)\end{array}$ & $\begin{array}{l}0.001 \\
(0.05)\end{array}$ & $\begin{array}{l}-0.006 \\
(-0.46)\end{array}$ & $\begin{array}{l}-0.001 \\
(-0.04)\end{array}$ \\
\hline State_Bank $\left(\alpha_{9}\right)$ & $\begin{array}{l}2.450 \\
(1.55)\end{array}$ & $\begin{array}{l}-2.637 \text { *** } \\
(-2.35)\end{array}$ & $\begin{array}{l}2.387 \\
(1.50)\end{array}$ & $\begin{array}{c}-2.687 * * \\
(-2.39)\end{array}$ & $\begin{array}{l}3.637 * \\
(1.83)\end{array}$ & $\begin{array}{l}-0.096 \\
(-0.05)\end{array}$ & $\begin{array}{l}-1.263 \\
(-1.29)\end{array}$ & $\begin{array}{l}-2.933 * \\
(-1.78)\end{array}$ & $\begin{array}{l}0.501 \\
(0.26)\end{array}$ & $\begin{array}{l}-2.517 \\
(-0.83)\end{array}$ & $\begin{array}{l}0.274 \\
(0.22)\end{array}$ & $\begin{array}{l}-0.649 \\
(-0.44)\end{array}$ & $\begin{array}{l}-1.705 \\
(-1.42)\end{array}$ & $\begin{array}{l}-1.087 \\
(-0.63)\end{array}$ \\
\hline Foreign_Bank $\left(\alpha_{10}\right)$ & $\begin{array}{l}3.009 * \\
(1.69)\end{array}$ & $\begin{array}{l}0.895 \\
(0.57)\end{array}$ & $\begin{array}{l}2.832 \\
(1.55)\end{array}$ & $\begin{array}{l}1.029 \\
(0.66)\end{array}$ & $\begin{array}{c}4.104 * * * \\
(1.98)\end{array}$ & $\begin{array}{l}2.099 \\
(0.93)\end{array}$ & $\begin{array}{l}3.062 \\
(1.17)\end{array}$ & $\begin{array}{l}-0.419 \\
(-0.14)\end{array}$ & $\begin{array}{c}4.046 * * \\
(1.99)\end{array}$ & $\begin{array}{l}2.747 \\
(0.89)\end{array}$ & $\begin{array}{l}-1.673 \\
(-1.23)\end{array}$ & $\begin{array}{l}-0.783 \\
(-0.49)\end{array}$ & $\begin{array}{c}3.482 * * \\
(1.99)\end{array}$ & $\begin{array}{l}0.135 \\
(0.06)\end{array}$ \\
\hline Subsidiary $\left(\alpha_{11}\right)$ & $\begin{array}{l}-1.844 \\
(-1.31)\end{array}$ & $\begin{array}{l}0.930 \\
(0.83)\end{array}$ & $\begin{array}{l}-1.775 \\
(-1.26)\end{array}$ & $\begin{array}{l}0.948 \\
(0.85)\end{array}$ & $\begin{array}{l}0.355 \\
(0.21)\end{array}$ & $\begin{array}{c}-4.859 * * * * \\
(-3.03)\end{array}$ & $\begin{array}{l}1.606 \\
(1.07)\end{array}$ & $\begin{array}{l}-0.734 \\
(-0.46)\end{array}$ & $\begin{array}{c}4.709 * * * \\
(2.77)\end{array}$ & $\begin{array}{l}-1.729 \\
(-0.82)\end{array}$ & $\begin{array}{l}0.488 \\
(0.39)\end{array}$ & $\begin{array}{l}-1.763 \\
(-1.59)\end{array}$ & $\begin{array}{l}-0.777 \\
(-0.76)\end{array}$ & $\begin{array}{l}-1.195 \\
(-0.80)\end{array}$ \\
\hline Young_Bank $\left(\alpha_{12}\right)$ & $\begin{array}{l}-0.728 \\
(-0.30)\end{array}$ & $\begin{array}{l}0.379 \\
(0.17)\end{array}$ & $\begin{array}{l}-0.765 \\
(-0.31)\end{array}$ & $\begin{array}{l}0.422 \\
(0.19)\end{array}$ & $\begin{array}{l}3.111 \\
(0.74)\end{array}$ & $\begin{array}{l}0.562 \\
(0.20)\end{array}$ & $\begin{array}{l}-0.786 \\
(-0.79)\end{array}$ & $\begin{array}{l}2.951 \\
(0.71)\end{array}$ & $\begin{array}{l}-2.567 \\
(-1.32)\end{array}$ & $\begin{array}{l}3.597 \\
(1.02)\end{array}$ & $\begin{array}{l}1.565 \\
(0.59)\end{array}$ & $\begin{array}{l}1.012 \\
(0.50)\end{array}$ & $\begin{array}{l}0.718 \\
(0.42)\end{array}$ & $\begin{array}{c}27.655 * * * \\
(7.45)\end{array}$ \\
\hline Middle_Aged_Bank $\left(\alpha_{13}\right)$ & $\begin{array}{l}1.213 \\
(0.91)\end{array}$ & $\begin{array}{l}-0.678 \\
(-0.68)\end{array}$ & $\begin{array}{l}1.210 \\
(0.922\end{array}$ & $\begin{array}{l}-0.771 \\
(-0.76)\end{array}$ & $\begin{array}{r}-0.570 \\
(-0.28)\end{array}$ & $\begin{array}{l}3.097 * \\
(1.82)\end{array}$ & $\begin{array}{c}-1.351 * * \\
(-2.13)\end{array}$ & $\begin{array}{l}-0.576 \\
(-0.47)\end{array}$ & $\begin{array}{l}-1.362 \\
(-1.03)\end{array}$ & $\begin{array}{l}0.992 \\
(0.66)\end{array}$ & $\begin{array}{l}-0.619 \\
(-0.67)\end{array}$ & $\begin{array}{l}-0.629 \\
(-0.73)\end{array}$ & $\begin{array}{l}0.427 \\
(0.32)\end{array}$ & $\begin{array}{l}0.149 \\
(0.13)\end{array}$ \\
\hline Domestic_Interest_Rate $\left(\alpha_{15}\right)$ & $\begin{array}{l}-0.013 \\
(-0.18)\end{array}$ & $\begin{array}{l}0.311 * * * \\
(2.66)\end{array}$ & $\begin{array}{l}-0.008 \\
(-0.10)\end{array}$ & $\begin{array}{l}0.335 * * * \\
(2.77)\end{array}$ & $\begin{array}{l}0.148 \\
(0.60)\end{array}$ & $\begin{array}{l}-0.043 \\
(-0.45)\end{array}$ & $\begin{array}{l}0.165 \\
(1.34)\end{array}$ & $\begin{array}{l}0.178 \\
(1.21)\end{array}$ & $\begin{array}{l}0.271 \\
(1.60)\end{array}$ & $\begin{array}{l}0.175 \\
(1.23)\end{array}$ & $\begin{array}{l}0.257 \\
(1.37)\end{array}$ & $\begin{array}{l}-0.146^{*} \\
(-1.71)\end{array}$ & $\begin{array}{l}0.170 \\
(1.31)\end{array}$ & $\begin{array}{l}-0.133 \\
(-0.35)\end{array}$ \\
\hline $\begin{array}{l}\text { Islamic_Bank } \times \\
\text { Domestic_Interest_Rate }\left(\alpha_{\text {ID }}\right)\end{array}$ & & & $\begin{array}{l}-0.209 \\
(-0.59)\end{array}$ & $\begin{array}{c}-0.355 * * \\
(-2.25)\end{array}$ & & & & & & & & & & \\
\hline $\mathrm{HHI}\left(\alpha_{16}\right)$ & $\begin{array}{c}-13.046 * * * * \\
(-2.61)\end{array}$ & $\begin{array}{l}4.679 \\
(0.72)\end{array}$ & $\begin{array}{l}-13.143 * * * \\
(-2.62)\end{array}$ & $\begin{array}{l}4.621 \\
(0.71)\end{array}$ & $\begin{array}{r}-10.477 \\
(-0.95)\end{array}$ & $\begin{array}{l}-5.938 \\
(-1.19)\end{array}$ & $\begin{array}{l}8.099 \\
(0.80)\end{array}$ & $\begin{array}{l}5.854 \\
(0.79)\end{array}$ & $\begin{array}{l}1.319 \\
(0.18)\end{array}$ & $\begin{array}{l}-3.810 \\
(-0.93)\end{array}$ & $\begin{array}{l}5.343 \\
(0.82)\end{array}$ & $\begin{array}{l}4.374 \\
(0.79)\end{array}$ & $\begin{array}{l}-1.571 \\
(-0.43)\end{array}$ & $\begin{array}{r}-8.379 \\
(-0.52)\end{array}$ \\
\hline GDP_Per_Capita $\left(\alpha_{17}\right)$ & $\begin{array}{l}0.082 \\
(0.28)\end{array}$ & $\begin{array}{l}0.156 \\
(1.44)\end{array}$ & $\begin{array}{l}0.086 \\
(0.29)\end{array}$ & $\begin{array}{l}0.166 \\
(1.53)\end{array}$ & $\begin{array}{l}0.023 \\
(0.04)\end{array}$ & $\begin{array}{l}-0.271 \\
(-0.59)\end{array}$ & $\begin{array}{l}-0.051 \\
(-0.25)\end{array}$ & $\begin{array}{l}0.110 \\
(0.76)\end{array}$ & $\begin{array}{l}-0.381 \\
(-1.06)\end{array}$ & $\begin{array}{l}0.070 \\
(0.15)\end{array}$ & $\begin{array}{l}0.095 \\
(0.35)\end{array}$ & $\begin{array}{l}0.174 \\
(1.32)\end{array}$ & $\begin{array}{l}0.240 \\
(1.37)\end{array}$ & $\begin{array}{r}-0.093 \\
(-0.30)\end{array}$ \\
\hline GDP_Per_Capita_Growth $\left(\alpha_{18}\right)$ & $\begin{array}{l}0.095 \\
(1.31)\end{array}$ & $\begin{array}{c}-0.193 * * \\
(-2.12)\end{array}$ & $\begin{array}{l}0.092 \\
(1.28)\end{array}$ & $\begin{array}{c}-0.181 * * \\
(-2.03)\end{array}$ & $\begin{array}{l}0.271 \\
(1.34)\end{array}$ & $\begin{array}{l}0.059 \\
(0.65)\end{array}$ & $\begin{array}{l}0.027 \\
(0.26)\end{array}$ & $\begin{array}{c}-0.338 * * \\
(-2.12)\end{array}$ & $\begin{array}{l}0.010 \\
(0.06)\end{array}$ & $\begin{array}{l}0.058 \\
(0.64)\end{array}$ & $\begin{array}{l}0.024 \\
(0.28)\end{array}$ & $\begin{array}{l}-0.146 \\
(-1.49)\end{array}$ & $\begin{array}{l}0.000 \\
(0.00)\end{array}$ & $\begin{array}{l}0.001 \\
(0.02)\end{array}$ \\
\hline Constant $\left(\alpha_{0}\right)$ & $\begin{array}{c}29.786 * * * * \\
(4.71)\end{array}$ & $\begin{array}{c}11.485^{*} \\
(1.86)\end{array}$ & $\begin{array}{c}29.928 * * * \\
(4.73)\end{array}$ & $\begin{array}{c}12.181 * \\
(1.95)\end{array}$ & $\begin{array}{r}29.423 \\
(1.24) \\
\end{array}$ & $\begin{array}{c}0.000 \\
(.)\end{array}$ & $\begin{array}{l}8.172^{*} \\
(1.75)\end{array}$ & $\begin{array}{c}19.755^{*} \\
(1.76)\end{array}$ & $\begin{array}{c}19.677 * \\
(1.84)\end{array}$ & $\begin{array}{c}33.249 \text { **** } \\
(3.43) \\
\end{array}$ & $\begin{array}{l}6.286 \\
(0.87) \\
\end{array}$ & $\begin{array}{c}16.851^{* *} \\
(2.44) \\
\end{array}$ & $\begin{array}{c}12.695^{* *} \\
(2.22)\end{array}$ & $\begin{array}{r}29.487 \\
(1.36) \\
\end{array}$ \\
\hline $\begin{array}{l}\text { Number of Obs } \\
\text { R-squared }\end{array}$ & $\begin{array}{c}798 \\
0.254\end{array}$ & $\begin{array}{l}1,099 \\
0.150\end{array}$ & $\begin{array}{l}798 \\
0.257\end{array}$ & $\begin{array}{l}1,099 \\
0.150\end{array}$ & $\begin{array}{c}397 \\
0.359\end{array}$ & $\begin{array}{l}401 \\
0.252\end{array}$ & $\begin{array}{c}544 \\
0.245\end{array}$ & $\begin{array}{l}556 \\
0.132\end{array}$ & $\begin{array}{l}463 \\
0.433\end{array}$ & $\begin{array}{l}468 \\
0.174\end{array}$ & $\begin{array}{l}478 \\
0.193\end{array}$ & $\begin{array}{l}489 \\
0.169\end{array}$ & $\begin{array}{c}863 \\
0.192\end{array}$ & $\begin{array}{c}428 \\
0.219\end{array}$ \\
\hline $\begin{array}{l}\mathrm{H}_{0}: \alpha_{15}=\alpha_{\mathrm{ID}}=0 \text { (F-stat.) } \\
\mathrm{H}_{0}: \alpha_{15}+\alpha_{1 \mathrm{ID}}=0 \text { (F-stat.) }\end{array}$ & & & $\begin{array}{l}0.35 \\
0.34\end{array}$ & $\begin{array}{c}9.25 * * * \\
0.01\end{array}$ & & & & & & & & & & \\
\hline
\end{tabular}

Dependent Variable: The ratio of loan loss reserves on gross loans is used as the credit risk proxy. 
Explanatory Variables: Islamic_Bank $=$ Islamic bank dummy, Islamic_Window_Bank $=$ Islamic window bank dummy, Size $=$ Logarithm of total assets, Market_Share $=$ Logarithm of market share of total assets, orthogonalized on Size, Capital_Asset_Ratio $=$ The ratio of equity capital on total assets, Loan_Growth $=$ Annual growth rate of gross loans, Noninterest_Income $=$ Share of non-interest income in total operating income, Cost_Inefficiency $=$ Cost to income ratio, State_Bank $=$ State-owned bank dummy, Foreign_Bank $=$ Foreign-owned bank dummy, Subsidiary $=$ Subsidiary dummy, Young_Bank $=$ Young bank dummy, Middle_Aged_Bank index, GDP_Per_Capita = GDP per capita, GDP_Per_Capita_Growth = Annual growth rate of GDP_Per_Capita.

In columns (1) and (2), we split the sample into two groups: Observations in countries with at least 90\% Muslims in their population are classified as one group ("Muslim+90") and the rest are placed in the other group ("Muslim-90"). Muslim+90 and Muslim-90 are the upper half and lower half of the observations sorted based on the Muslim population. In columns (3) and (4), we investigate whether credit risk of Islamic banks is more samples. In columns (5) to (8), we split the full sample into four sub-samples: high leveraged banks in Muslim+90, low leveraged banks in Muslim+90, high leveraged banks in Muslim-90 and low leveraged banks in Muslim-90. In columns (9) to (12), we split the sample into four sub-samples: high leveraged small banks, low leveraged small banks, high leveraged large banks and low leveraged large banks. In columns (13) and (14), we estimate the model, using the pre-crisis period (2003-2007) and the crisis period (2008-2009) sub-samples.

We apply random effect technique with robust standard errors for our estimations. All the accounting and macro level variables are lagged for one period. Year and country dummies are included in the model, but not reported in the table. Robust $\mathrm{Z}$-statistics are reported in parentheses. ***, ** and $*$ indicate significance at $1 \%, 5 \%$ and $10 \%$ respectively. 
Annex 6. Insolvency Risk Model

This table presents the estimation of insolvency risk model, using different sub-samples: Muslim+90/Muslim-90, small/large banks and pre-crisis/the crisis periods.

\begin{tabular}{|c|c|c|c|c|c|c|c|c|c|c|c|c|c|c|}
\hline \multirow[b]{3}{*}{ Variables } & (1) & (2) & (3) & (4) & (5) & (6) & (7) & (8) & (9) & (10) & $(11)$ & $(12)$ & (13) & (14) \\
\hline & Muslim +90 & Muslim-90 & Muslim +90 & Muslim-90 & \multicolumn{3}{|c|}{ Small Banks } & \multicolumn{3}{|c|}{ Large Banks } & \multirow{2}{*}{$\begin{array}{c}\begin{array}{c}\text { Pre-Crisis } \\
\text { Period }\end{array} \\
\text { Zscore_rw }\end{array}$} & \multirow{2}{*}{\multicolumn{2}{|c|}{$\begin{array}{l}\text { Crisis Period } \\
\text { Small Banks } \\
\text { Zscore_rw }\end{array}$}} & \multirow{2}{*}{$\frac{\text { Large Banks }}{\text { Zscore_rw }}$} \\
\hline & Zscore_rw & Zscore_rw & Zscore_rw & Zscore_rw & Zscore_rw & Zscore_Pl_rw & Zscore_P2_rw & $\begin{array}{l}\text { Zscore_rw } \\
\end{array}$ & Zscore_P1_rw & Zscore_P2_rw & & & & \\
\hline Islamic_Bank ( $\left.\beta_{1}\right)$ & $\begin{array}{l}0.317 \\
(1.51)\end{array}$ & $\begin{array}{l}-0.080 \\
(-0.35)\end{array}$ & $\begin{array}{l}0.516 \\
(1.48)\end{array}$ & $\begin{array}{l}0.001 \\
(0.00)\end{array}$ & $\begin{array}{c}0.388 * * \\
(2.12)\end{array}$ & $\begin{array}{l}0.193 \\
(1.23)\end{array}$ & $\begin{array}{l}0.352 * \\
(1.84)\end{array}$ & $\begin{array}{l}-0.131 \\
(-0.62)\end{array}$ & $\begin{array}{l}-0.072 \\
(-0.43)\end{array}$ & $\begin{array}{l}-0.023 \\
(-0.11)\end{array}$ & $\begin{array}{l}0.175 \\
(1.00)\end{array}$ & $\begin{array}{l}-0.426^{*} \\
(-1.69)\end{array}$ & $\begin{array}{l}0.345 \\
(0.70)\end{array}$ & $\begin{array}{l}-0.677 * * \\
(-2.15)\end{array}$ \\
\hline Islamic_Window_Bank ( $\left.\beta_{2}\right)$ & $\begin{array}{l}0.248 \\
(1.04)\end{array}$ & $\begin{array}{l}0.193 \\
(0.77)\end{array}$ & $\begin{array}{l}0.258 \\
(1.08)\end{array}$ & $\begin{array}{l}0.197 \\
(0.78)\end{array}$ & $\begin{array}{l}0.206 \\
(0.86)\end{array}$ & $\begin{array}{l}0.339 \\
(1.63)\end{array}$ & $\begin{array}{l}0.218 \\
(0.88)\end{array}$ & $\begin{array}{l}0.154 \\
(0.83)\end{array}$ & $\begin{array}{l}0.232 \\
(1.33)\end{array}$ & $\begin{array}{l}0.287 \\
(1.52)\end{array}$ & $\begin{array}{l}0.100 \\
(0.57)\end{array}$ & $\begin{array}{l}0.365 \\
(1.54)\end{array}$ & $\begin{array}{l}0.018 \\
(0.04)\end{array}$ & $\begin{array}{l}0.483^{*} \\
(1.66)\end{array}$ \\
\hline Size $\left(\beta_{3}\right)$ & $\begin{array}{l}-0.071 * \\
(-1.67)\end{array}$ & $\begin{array}{l}-0.045 \\
(-0.91)\end{array}$ & $\begin{array}{l}-0.069 \\
(-1.63)\end{array}$ & $\begin{array}{l}-0.049 \\
(-0.93)\end{array}$ & $\begin{array}{l}-0.052 \\
(-0.84)\end{array}$ & $\begin{array}{c}0.155 * * * \\
(2.68)\end{array}$ & $\begin{array}{l}-0.068 \\
(-1.05)\end{array}$ & $\begin{array}{c}-0.126 * * * \\
(-2.74)\end{array}$ & $\begin{array}{l}-0.014 \\
(-0.34)\end{array}$ & $\begin{array}{c}-0.141 * * * * \\
(-3.00)\end{array}$ & $\begin{array}{l}-0.042 \\
(-1.30)\end{array}$ & $\begin{array}{l}0.162 \\
(0.89)\end{array}$ & $\begin{array}{c}-0.726 * * \\
(-2.10)\end{array}$ & $\begin{array}{l}0.229 \\
(0.99)\end{array}$ \\
\hline Market_Share $\left(\beta_{4}\right)$ & $\begin{array}{l}-0.120 \\
(-1.23)\end{array}$ & $\begin{array}{l}0.006 \\
(0.05)\end{array}$ & $\begin{array}{l}-0.121 \\
(-1.26)\end{array}$ & $\begin{array}{l}0.020 \\
(0.16)\end{array}$ & $\begin{array}{c}-0.161 * \\
(-1.82)\end{array}$ & $\begin{array}{l}-0.067 \\
(-0.73)\end{array}$ & $\begin{array}{l}-0.169 * \\
(-1.77)\end{array}$ & $\begin{array}{l}0.120 \\
(0.85)\end{array}$ & $\begin{array}{l}0.015 \\
(0.13)\end{array}$ & $\begin{array}{l}0.107 \\
(0.71)\end{array}$ & $\begin{array}{l}-0.055 \\
(-0.68)\end{array}$ & $\begin{array}{l}-1.146 \\
(-1.58)\end{array}$ & $\begin{array}{l}0.612 \\
(0.48)\end{array}$ & $\begin{array}{l}-1.540 \\
(-1.64)\end{array}$ \\
\hline Loan_Total_Earning_Asset_Ratio $\left(\beta_{5}\right)$ & $\begin{array}{l}0.001 \\
(0.55)\end{array}$ & $\begin{array}{l}0.000 \\
(0.00)\end{array}$ & $\begin{array}{l}0.002 \\
(0.57)\end{array}$ & $\begin{array}{l}0.000 \\
(0.03)\end{array}$ & $\begin{array}{l}0.002 \\
(0.93)\end{array}$ & $\begin{array}{l}0.002 \\
(0.86)\end{array}$ & $\begin{array}{l}0.002 \\
(0.87)\end{array}$ & $\begin{array}{l}0.001 \\
(0.27)\end{array}$ & $\begin{array}{l}0.002 \\
(0.72)\end{array}$ & $\begin{array}{l}0.001 \\
(0.23)\end{array}$ & $\begin{array}{l}0.002 \\
(0.87)\end{array}$ & $\begin{array}{l}-0.003 \\
(-0.85)\end{array}$ & $\begin{array}{l}-0.007 \\
(-1.43)\end{array}$ & $\begin{array}{c}-0.001 \\
(-0.26)\end{array}$ \\
\hline Asset_Growth $\left(\beta_{6}\right)$ & $\begin{array}{l}0.000 \\
(0.17)\end{array}$ & $\begin{array}{l}0.001 \\
(0.62)\end{array}$ & $\begin{array}{l}0.000 \\
(0.19)\end{array}$ & $\begin{array}{l}0.001 \\
(0.64)\end{array}$ & $\begin{array}{l}-0.000 \\
(-0.18)\end{array}$ & $\begin{array}{l}-0.001 \\
(-0.80)\end{array}$ & $\begin{array}{l}-0.000 \\
(-0.04)\end{array}$ & $\begin{array}{l}0.002 \\
(1.26)\end{array}$ & $\begin{array}{l}0.001 \\
(0.90)\end{array}$ & $\begin{array}{l}0.002 \\
(1.15)\end{array}$ & $\begin{array}{l}-0.001 \\
(-0.33)\end{array}$ & $\begin{array}{l}0.001 \\
(0.58)\end{array}$ & $\begin{array}{l}0.001 \\
(0.45)\end{array}$ & $\begin{array}{l}0.002 \\
(0.81)\end{array}$ \\
\hline Noninterest_Income $\left(\beta_{7}\right)$ & $\begin{array}{l}-0.004 * \\
(-1.66)\end{array}$ & $\begin{array}{l}-0.006 \\
(-1.51)\end{array}$ & $\begin{array}{l}-0.004 \\
(-1.59)\end{array}$ & $\begin{array}{l}-0.006 \\
(-1.51)\end{array}$ & $\begin{array}{l}-0.005 \\
(-1.39)\end{array}$ & $\begin{array}{l}-0.006 \\
(-1.49)\end{array}$ & $\begin{array}{l}-0.003 \\
(-0.82)\end{array}$ & $\begin{array}{l}-0.004 \\
(-1.40)\end{array}$ & $\begin{array}{c}-0.007 * * \\
(-2.45)\end{array}$ & $\begin{array}{c}-0.007 \text { ** } \\
(-2.11)\end{array}$ & $\begin{array}{l}-0.003 \\
(-1.14)\end{array}$ & $\begin{array}{l}0.004 \\
(0.93)\end{array}$ & $\begin{array}{l}0.004 \\
(0.69)\end{array}$ & $\begin{array}{l}0.003 \\
(0.50)\end{array}$ \\
\hline Cost_Inefficiency $\left(\beta_{8}\right)$ & $\begin{array}{c}-0.010^{* * * *} \\
(-4.39)\end{array}$ & $\begin{array}{c}-0.008 * * * * \\
(-3.72)\end{array}$ & $\begin{array}{c}-0.010^{* * * *} \\
(-4.38)\end{array}$ & $\begin{array}{c}-0.008 * * * * \\
(-3.72)\end{array}$ & $\begin{array}{c}-0.011 * * * * \\
(-5.49)\end{array}$ & $\begin{array}{c}-0.019^{* * * * *} \\
(-6.02)\end{array}$ & $\begin{array}{c}-0.010^{* * * *} \\
(-5.13)\end{array}$ & $\begin{array}{c}-0.007 \text { ***** } \\
(-2.70)\end{array}$ & $\begin{array}{c}-0.017 * * * * \\
(-4.98)\end{array}$ & $\begin{array}{c}-0.007 * * * * \\
(-3.10)\end{array}$ & $\begin{array}{c}-0.011^{* * * *} \\
(-4.38)\end{array}$ & $\begin{array}{l}-0.004 \\
(-1.14)\end{array}$ & $\begin{array}{l}0.002 \\
(0.33)\end{array}$ & $\begin{array}{c}-0.007 * \\
(-1.91)\end{array}$ \\
\hline State_Bank $\left(\beta_{9}\right)$ & $\begin{array}{l}0.007 \\
(0.03)\end{array}$ & $\begin{array}{l}0.237 \\
(1.32)\end{array}$ & $\begin{array}{l}-0.003 \\
(-0.01)\end{array}$ & $\begin{array}{l}0.233 \\
(1.30)\end{array}$ & $\begin{array}{c}0.356^{*} \\
(1.76)\end{array}$ & $\begin{array}{l}0.193 \\
(1.07)\end{array}$ & $\begin{array}{c}0.362^{*} \\
(1.69)\end{array}$ & $\begin{array}{l}0.173 \\
(0.96)\end{array}$ & $\begin{array}{l}0.035 \\
(0.23)\end{array}$ & $\begin{array}{l}0.207 \\
(1.08)\end{array}$ & $\begin{array}{l}0.235 \\
(1.47)\end{array}$ & $\begin{array}{l}-0.190 \\
(-0.78)\end{array}$ & $\begin{array}{l}0.120 \\
(0.24)\end{array}$ & $\begin{array}{l}-0.435 \\
(-1.49)\end{array}$ \\
\hline Foreign_Bank $\left(\beta_{10}\right)$ & $\begin{array}{l}-0.308 \\
(-1.32)\end{array}$ & $\begin{array}{l}0.018 \\
(0.09)\end{array}$ & $\begin{array}{l}-0.314 \\
(-1.34)\end{array}$ & $\begin{array}{l}0.022 \\
(0.10)\end{array}$ & $\begin{array}{c}-0.357 * * \\
(-1.99)\end{array}$ & $\begin{array}{l}-0.212 \\
(-1.14)\end{array}$ & $\begin{array}{l}-0.333^{*} \\
(-1.84)\end{array}$ & $\begin{array}{l}0.074 \\
(0.32)\end{array}$ & $\begin{array}{l}-0.141 \\
(-0.72)\end{array}$ & $\begin{array}{l}0.138 \\
(0.59)\end{array}$ & $\begin{array}{l}-0.109 \\
(-0.55)\end{array}$ & $\begin{array}{l}0.127 \\
(0.41)\end{array}$ & $\begin{array}{l}-0.356 \\
(-0.87)\end{array}$ & $\begin{array}{l}0.334 \\
(0.86)\end{array}$ \\
\hline Subsidiary $\left(\beta_{11}\right)$ & $\begin{array}{l}-0.189 \\
(-1.18)\end{array}$ & $\begin{array}{c}-0.371 * * \\
(-2.12)\end{array}$ & $\begin{array}{l}-0.180 \\
(-1.12)\end{array}$ & $\begin{array}{c}-0.371 * * \\
(-2.12)\end{array}$ & $\begin{array}{c}-0.392 * * \\
(-2.12)\end{array}$ & $\begin{array}{l}-0.308 \\
(-1.36)\end{array}$ & $\begin{array}{c}-0.442 * * * \\
(-2.11)\end{array}$ & $\begin{array}{l}-0.131 \\
(-0.89)\end{array}$ & $\begin{array}{l}-0.035 \\
(-0.25)\end{array}$ & $\begin{array}{l}-0.067 \\
(-0.46)\end{array}$ & $\begin{array}{l}-0.191 \\
(-1.23)\end{array}$ & $\begin{array}{c}-0.586 \text { **** } \\
(-3.15)\end{array}$ & $\begin{array}{c}-0.898 * * * * \\
(-2.73)\end{array}$ & $\begin{array}{c}-0.592 * * \\
(-2.53)\end{array}$ \\
\hline Young_Bank $\left(\beta_{12}\right)$ & $\begin{array}{c}-0.672 * * \\
(-2.35)\end{array}$ & $\begin{array}{l}-0.101 \\
(-0.33)\end{array}$ & $\begin{array}{c}-0.673 * * \\
(-2.35)\end{array}$ & $\begin{array}{l}-0.093 \\
(-0.31)\end{array}$ & $\begin{array}{l}-0.107 \\
(-0.44)\end{array}$ & $\begin{array}{c}-0.688 * * \\
(-2.24)\end{array}$ & $\begin{array}{l}-0.003 \\
(-0.01)\end{array}$ & $\begin{array}{l}-0.509 \\
(-1.32)\end{array}$ & $\begin{array}{c}-0.611^{*} \\
(-1.74)\end{array}$ & $\begin{array}{l}-0.323 \\
(-0.91)\end{array}$ & $\begin{array}{l}-0.486 \\
(-1.61)\end{array}$ & $\begin{array}{l}-0.456 \\
(-1.23)\end{array}$ & $\begin{array}{c}0.000 \\
(.)\end{array}$ & $\begin{array}{l}-0.351 \\
(-0.68)\end{array}$ \\
\hline Middle_Aged_Bank ( $\left.\beta_{13}\right)$ & $\begin{array}{l}-0.377^{*} \\
(-1.89)\end{array}$ & $\begin{array}{c}-0.002 \\
(-0.01)\end{array}$ & $\begin{array}{c}-0.374 * \\
(-1.87)\end{array}$ & $\begin{array}{l}-0.006 \\
(-0.04)\end{array}$ & $\begin{array}{l}-0.096 \\
(-0.63)\end{array}$ & $\begin{array}{l}0.231 \\
(1.29)\end{array}$ & $\begin{array}{l}-0.146 \\
(-0.96)\end{array}$ & $\begin{array}{l}-0.078 \\
(-0.34)\end{array}$ & $\begin{array}{l}-0.207 \\
(-0.96)\end{array}$ & $\begin{array}{l}-0.020 \\
(-0.10)\end{array}$ & $\begin{array}{l}-0.233 \\
(-1.34)\end{array}$ & $\begin{array}{l}0.093 \\
(0.37)\end{array}$ & $\begin{array}{l}0.023 \\
(0.05)\end{array}$ & $\begin{array}{l}0.037 \\
(0.11)\end{array}$ \\
\hline Domestic_Interest_Rate $\left(\beta_{15}\right)$ & $\begin{array}{c}-0.054 * * * * \\
(-4.96)\end{array}$ & $\begin{array}{c}-0.007 \\
(-0.18)\end{array}$ & $\begin{array}{c}-0.054 * * * * \\
(-4.98)\end{array}$ & $\begin{array}{l}-0.005 \\
(-0.13)\end{array}$ & $\begin{array}{l}-0.014 \\
(-0.53)\end{array}$ & $\begin{array}{l}0.009 \\
(0.34)\end{array}$ & $\begin{array}{l}-0.008 \\
(-0.31)\end{array}$ & $\begin{array}{c}-0.060 \text { **** } \\
(-4.70)\end{array}$ & $\begin{array}{c}-0.047 * * * * * \\
(-3.42)\end{array}$ & $\begin{array}{c}-0.060^{* * * *} \\
(-5.84)\end{array}$ & $\begin{array}{c}-0.052^{* * * * *} \\
(-3.36)\end{array}$ & $\begin{array}{l}0.051 \\
(0.49)\end{array}$ & $\begin{array}{l}-0.077 \\
(-0.51)\end{array}$ & $\begin{array}{l}0.098 \\
(0.67)\end{array}$ \\
\hline Islamic_Bank $\times$ Domestic_Interest_Rate $\left(\beta_{1 \mathrm{ID}}\right)$ & & & $\begin{array}{l}-0.032 \\
(-0.81)\end{array}$ & $\begin{array}{l}-0.017 \\
(-0.29)\end{array}$ & & & & & & & & & & \\
\hline HHI $\left(\beta_{16}\right)$ & $\begin{array}{l}-0.785 \\
(-1.08)\end{array}$ & $\begin{array}{c}-2.149 * * \\
(-2.41)\end{array}$ & $\begin{array}{l}-0.780 \\
(-1.07)\end{array}$ & $\begin{array}{c}-2.152 * * \\
(-2.41)\end{array}$ & $\begin{array}{l}0.068 \\
(0.10)\end{array}$ & $\begin{array}{l}0.037 \\
(0.03)\end{array}$ & $\begin{array}{l}-0.212 \\
(-0.31)\end{array}$ & $\begin{array}{c}-1.915^{* * *} \\
(-2.00)\end{array}$ & $\begin{array}{c}-1.802^{* * *} \\
(-2.35)\end{array}$ & $\begin{array}{c}-2.135 * * \\
(-2.09)\end{array}$ & $\begin{array}{l}-0.816 \\
(-1.09)\end{array}$ & $\begin{array}{l}-0.343 \\
(-0.08)\end{array}$ & $\begin{array}{l}-6.343 \\
(-0.90)\end{array}$ & $\begin{array}{l}-1.624 \\
(-0.27)\end{array}$ \\
\hline GDP_Per_Capita $\left(\beta_{17}\right)$ & $\begin{array}{l}-0.042 \\
(-1.19)\end{array}$ & $\begin{array}{c}-0.099 * * * * \\
(-2.72)\end{array}$ & $\begin{array}{c}-0.042 \\
(-1.17)\end{array}$ & $\begin{array}{c}-0.099 * * * * \\
(-2.70)\end{array}$ & $\begin{array}{l}-0.034 \\
(-0.86)\end{array}$ & $\begin{array}{l}-0.048 * \\
(-1.72)\end{array}$ & $\begin{array}{l}-0.040 \\
(-1.01)\end{array}$ & $\begin{array}{c}-0.072 * * \\
(-2.39)\end{array}$ & $\begin{array}{l}-0.041 \\
(-1.64)\end{array}$ & $\begin{array}{c}-0.080 * * \\
(-2.55)\end{array}$ & $\begin{array}{c}-0.067 * \\
(-1.68)\end{array}$ & $\begin{array}{l}-0.138 \\
(-1.22)\end{array}$ & $\begin{array}{l}-0.261 \\
(-1.22)\end{array}$ & $\begin{array}{l}-0.128 \\
(-0.90)\end{array}$ \\
\hline GDP_Per_Capita_Growth $\left(\beta_{18}\right)$ & $\begin{array}{l}-0.013 \\
(-1.11)\end{array}$ & $\begin{array}{l}0.003 \\
(0.15)\end{array}$ & $\begin{array}{l}-0.014 \\
(-1.13)\end{array}$ & $\begin{array}{l}0.003 \\
(0.14)\end{array}$ & $\begin{array}{l}-0.009 \\
(-0.75)\end{array}$ & $\begin{array}{l}0.001 \\
(0.07)\end{array}$ & $\begin{array}{l}-0.014 \\
(-1.16)\end{array}$ & $\begin{array}{l}0.002 \\
(0.11)\end{array}$ & $\begin{array}{l}0.003 \\
(0.14)\end{array}$ & $\begin{array}{l}0.002 \\
(0.13)\end{array}$ & $\begin{array}{l}-0.016 \\
(-1.38)\end{array}$ & $\begin{array}{l}0.054 \\
(0.95)\end{array}$ & $\begin{array}{l}0.009 \\
(0.19)\end{array}$ & $\begin{array}{l}0.073 \\
(0.81)\end{array}$ \\
\hline Constant $\left(\beta_{0}\right)$ & $\begin{array}{c}0.000 \\
(.)\end{array}$ & $\begin{array}{l}5.983 * * * * \\
(7.05)\end{array}$ & $\begin{array}{l}7.529 * * * \\
(5.04)\end{array}$ & $\begin{array}{c}6.028 * * * \\
(6.88) \\
\end{array}$ & $\begin{array}{l}5.235 * * * \\
(4.97)\end{array}$ & $\begin{array}{l}0.504 \\
(0.52)\end{array}$ & $\begin{array}{l}5.254 * * * \\
(4.75)\end{array}$ & $\begin{array}{c}7.395 * * * \\
(8.57)\end{array}$ & $\begin{array}{l}3.350^{* * * *} \\
(4.24)\end{array}$ & $\begin{array}{c}7.586 * * * * \\
(8.69)\end{array}$ & $\begin{array}{l}0.000 \\
(.)\end{array}$ & $\begin{array}{l}2.069 \\
(0.48)\end{array}$ & $\begin{array}{c}18.794 * * * \\
(2.66) \\
\end{array}$ & $\begin{array}{l}0.696 \\
(0.13)\end{array}$ \\
\hline $\begin{array}{l}\text { Number of Obs } \\
\text { R-squared }\end{array}$ & $\begin{array}{c}839 \\
0.205\end{array}$ & $\begin{array}{l}1,071 \\
0.141\end{array}$ & $\begin{array}{c}839 \\
0.204\end{array}$ & $\begin{array}{l}1,071 \\
0.141\end{array}$ & $\begin{array}{c}896 \\
0.206\end{array}$ & $\begin{array}{c}841 \\
0.251\end{array}$ & $\begin{array}{c}902 \\
0.207\end{array}$ & $\begin{array}{l}1,014 \\
0.191\end{array}$ & $\begin{array}{c}972 \\
0.252\end{array}$ & $\begin{array}{l}1,029 \\
0.215\end{array}$ & $\begin{array}{c}984 \\
0.174\end{array}$ & $\begin{array}{c}441 \\
0.242\end{array}$ & $\begin{array}{c}145 \\
0.379\end{array}$ & $\begin{array}{c}296 \\
0.315\end{array}$ \\
\hline $\begin{array}{l}\mathrm{H}_{0}: \beta_{15}=\beta_{\mathrm{ID}}=0 \text { (F-stat.) } \\
\mathrm{H}_{0} ; \beta_{15}+\beta_{\mathrm{ID}}=0 \text { (F-stat.) }\end{array}$ & & & $\begin{array}{l}26.22 * * * \\
4.62^{* * *}\end{array}$ & $\begin{array}{l}0.12 \\
0.12\end{array}$ & & & & & & & & & & \\
\hline
\end{tabular}


Dependent Variables: Zscore_rw = Logarithm of rolling-window Zscore which is equal to $($ ROAA+Capital_Asset_Ratio $) / S D R O A A \_r w, R O A A=$ Return on average assets, Capital_Asset_Ratio $=$ Equity capital to asset ratio, SDROAA_rw $=$ Standard deviation of $R O A A$ over 3 years (current year and two previous consecutive years). Banks need to have three consecutive observations. Acquiring banks are excluded from the sample, since the volatility on their assets returns can be due to the acquisition. ZScore_PI_rw = Logarithm of ROAA/SDROAA3_rw,ZZscore_P2_rw = Logarithm of Capital_Asset_RatiolSDROAA3_rw.

Explanatory Variables: Islamic_Bank $=$ Islamic bank dummy, Islamic_Window_Bank $=$ Islamic window bank dummy, Size $=$ Logarithm of total assets, Market_Share $=$ Logarithm of market share of total assets, orthogonalized on Size, Loan_Total_Earning_Asset_Ratio $=$ Share of net loans in total earning assets, Asset_Growth $=$ Annual growth rate of total assets, Noninterest_Income $=$ Share of non-interest income in total operating income, Cost_Inefficiency = Cost to income ratio, population, Domestic_Interest_Rate $=$ Domestic interest rate, Islamic_Bank $\times$ Domestic_Interest_Rate $=$ Interaction term of Islamic _Bank and Domestic_Interest_Rate, HHI = Hirschman-Herfindahl index, GDP_Per_Capita $=$ GDP per capita, GDP_Per_Capita_Growth = Annual growth rate of GDP_Per_Capita.

In columns (1) and (2), we split the sample into two groups: Observations in countries with at least 90\% Muslims in their population are classified as one group ("Muslim+90") and the rest are placed in the other group ("Muslim-90"). Muslim+90 and interest rate compared conventional banks, by adding the interaction term of Islamic Bank and Domestic Interest Rate (Islamic Bank $\times$ Domestic Interest Rate) to the Muslim +90 and Muslim-90 sub-samples. In columns (5) to (7), we estimate insolvency risk model on the small banks sub-sample, using Zscore $r w$, Zscore P1_rw and Zscore_P2_rw as the dependent variables, respectively. In columns (8) to (10), we estimate insolvency risk model on the large banks sub-sample, using Zscore_rw, Zscore PI $r w$ and Zscore_P2_rw as the dependent variables, respectively. In columns (11) and (12), we estimate the model, using Zscore_rw as the dependent variable and the pre-crisis period (2003-2007) and the crisis period (2008-2009) sub-samples. In columns (13) and (14), we estimate the model, using the small and large banks sub-samples during the crisis period (2008-2009).

We apply random effect technique with robust standard errors for our estimations. All the accounting and macro level variables are lagged for one period. Year and country dummies are included in the model, but not reported in the table. Robust zstatistics are reported in parentheses. $* * * * *$ and $*$ indicate significance at $1 \%, 5 \%$ and $10 \%$ respectively. 
Annex 7. Bank Interest Rate Model

This table presents the estimation of bank interest rate model. We investigate the sensitivity of interest income and expense of Islamic banks to domestic interest rate during the pre-crisis period (columns 1-5) and the crisis-period (columns 6-10).

\begin{tabular}{|c|c|c|c|c|c|c|c|c|c|c|}
\hline \multirow[b]{2}{*}{ Variables } & \multicolumn{5}{|c|}{ Pre-Crisis Period (2003-2007) } & \multicolumn{5}{|c|}{ Crisis Period (2008-2009) } \\
\hline & $\begin{array}{l}\text { (1) } \\
\text { Net_Interest_Margin } \\
\text { (A) }\end{array}$ & $\begin{array}{c}\text { (2) } \\
\text { Interest_Income_Rate } \\
\text { (B) }\end{array}$ & $\begin{array}{c}\text { (3) } \\
\text { Interest_Expense_Rate } \\
\text { (C) }\end{array}$ & $\begin{array}{l}\text { (4) } \\
\text { Loan_Rate } \\
\text { (D) }\end{array}$ & $\begin{array}{c}\text { (5) } \\
\text { Deposit_Rate } \\
\text { (E) }\end{array}$ & $\begin{array}{l}(6) \\
\mathrm{A}\end{array}$ & $\begin{array}{l}\text { (7) } \\
\mathrm{B}\end{array}$ & $\begin{array}{l}(8) \\
\mathrm{C}\end{array}$ & $\begin{array}{l}(9) \\
\mathrm{D}\end{array}$ & $\begin{array}{c}(10) \\
\mathrm{E}\end{array}$ \\
\hline Islamic_Bank $\left(\gamma_{1}\right)$ & $\begin{array}{l}0.159 \\
(0.46)\end{array}$ & $\begin{array}{l}0.009 \\
(0.02)\end{array}$ & $\begin{array}{l}-0.216 \\
(-0.61)\end{array}$ & $\begin{array}{l}0.361 \\
(0.33)\end{array}$ & $\begin{array}{l}0.451 \\
(0.68)\end{array}$ & $\begin{array}{l}2.141^{* * * *} \\
(3.52)\end{array}$ & $\begin{array}{l}1.776^{* *} \\
(2.27)\end{array}$ & $\begin{array}{l}0.563 \\
(0.93)\end{array}$ & $\begin{array}{l}2.399 * * * \\
(2.75)\end{array}$ & $\begin{array}{l}0.908 \\
(1.59)\end{array}$ \\
\hline Islamic_Window_Bank $\left(\gamma_{2}\right)$ & $\begin{array}{l}0.128 \\
(0.51)\end{array}$ & $\begin{array}{l}0.115 \\
(0.34)\end{array}$ & $\begin{array}{l}0.043 \\
(0.19)\end{array}$ & $\begin{array}{l}0.500 \\
(0.62)\end{array}$ & $\begin{array}{l}0.034 \\
(0.07)\end{array}$ & $\begin{array}{l}0.760^{* * *} \\
(2.13)\end{array}$ & $\begin{array}{l}0.645 \\
(1.29)\end{array}$ & $\begin{array}{l}0.312 \\
(0.84)\end{array}$ & $\begin{array}{l}0.669 \\
(1.03)\end{array}$ & $\begin{array}{l}-0.038 \\
(-0.10)\end{array}$ \\
\hline $\operatorname{Size}\left(\gamma_{3}\right)$ & $\begin{array}{l}-0.039 \\
(-0.76)\end{array}$ & $\begin{array}{l}-0.091 \\
(-1.35)\end{array}$ & $\begin{array}{l}0.019 \\
(0.39)\end{array}$ & $\begin{array}{l}-0.113 \\
(-0.87)\end{array}$ & $\begin{array}{l}-0.052 \\
(-0.60)\end{array}$ & $\begin{array}{l}0.151 \\
(0.81)\end{array}$ & $\begin{array}{c}1.226^{* * * *} \\
(2.93)\end{array}$ & $\begin{array}{c}1.166^{* * *} \\
(2.49)\end{array}$ & $\begin{array}{c}0.766 * \\
(1.80)\end{array}$ & $\begin{array}{c}1.142 * * * \\
(2.68)\end{array}$ \\
\hline Market_Share $\left(\gamma_{4}\right)$ & $\begin{array}{l}0.033 \\
(0.19)\end{array}$ & $\begin{array}{l}0.268 \\
(1.21)\end{array}$ & $\begin{array}{l}-0.067 \\
(-0.51)\end{array}$ & $\begin{array}{l}-0.624 \\
(-1.21)\end{array}$ & $\begin{array}{l}-0.092 \\
(-0.33)\end{array}$ & $\begin{array}{l}-0.510 \\
(-0.74)\end{array}$ & $\begin{array}{c}-5.549 * * * \\
(-3.45)\end{array}$ & $\begin{array}{c}-5.204 * * * \\
(-2.69)\end{array}$ & $\begin{array}{c}-3.610 \text { ** } \\
(-2.13)\end{array}$ & $\begin{array}{c}-5.098^{* * * *} \\
(-3.01)\end{array}$ \\
\hline Capital_Asset_Ratio $\left(\gamma_{5}\right)$ & $\begin{array}{l}0.009 \\
(1.38)\end{array}$ & $\begin{array}{l}-0.007 \\
(-0.88)\end{array}$ & $\begin{array}{l}-0.008 \\
(-1.07)\end{array}$ & $\begin{array}{l}-0.011 \\
(-0.74)\end{array}$ & $\begin{array}{l}-0.005 \\
(-0.42)\end{array}$ & $\begin{array}{l}0.004 \\
(0.49)\end{array}$ & $\begin{array}{c}-0.022 * \\
(-1.68)\end{array}$ & $\begin{array}{c}-0.030 * * * \\
(-2.98)\end{array}$ & $\begin{array}{l}-0.015 \\
(-0.87)\end{array}$ & $\begin{array}{c}-0.023 \text { **** } \\
(-2.64)\end{array}$ \\
\hline Noninterest_Income $\left(\gamma_{6}\right)$ & $\begin{array}{c}-0.018^{* * *} \\
(-4.86)\end{array}$ & $\begin{array}{c}-0.010^{* *} \\
(-2.29)\end{array}$ & $\begin{array}{c}0.012 * * * \\
(3.22)\end{array}$ & $\begin{array}{l}0.005 \\
(0.60)\end{array}$ & $\begin{array}{l}-0.003 \\
(-0.39)\end{array}$ & $\begin{array}{l}-0.007 \\
(-1.34)\end{array}$ & $\begin{array}{l}0.000 \\
(0.01)\end{array}$ & $\begin{array}{l}0.017 \\
(1.06)\end{array}$ & $\begin{array}{l}0.008 \\
(0.65)\end{array}$ & $\begin{array}{l}0.008 \\
(1.05)\end{array}$ \\
\hline Cost_Inefficiency $\left(\gamma_{7}\right)$ & $\begin{array}{c}-0.017 * * * \\
(-6.13)\end{array}$ & $\begin{array}{c}-0.013 * * * \\
(-3.75)\end{array}$ & $\begin{array}{l}0.000 \\
(0.13)\end{array}$ & $\begin{array}{c}-0.013 * * \\
(-2.09)\end{array}$ & $\begin{array}{l}-0.003 \\
(-0.48)\end{array}$ & $\begin{array}{c}-0.007 * \\
(-1.86)\end{array}$ & $\begin{array}{l}0.003 \\
(0.72)\end{array}$ & $\begin{array}{c}0.010^{* * * *} \\
(2.69)\end{array}$ & $\begin{array}{c}0.014 * * \\
(2.35)\end{array}$ & $\begin{array}{c}0.017 * * * \\
(3.30)\end{array}$ \\
\hline Loan_Loss_Reserve $\left(\gamma_{8}\right)$ & $\begin{array}{l}0.002 \\
(0.24)\end{array}$ & $\begin{array}{l}0.004 \\
(0.39)\end{array}$ & $\begin{array}{l}0.004 \\
(0.59)\end{array}$ & $\begin{array}{l}-0.027 \\
(-1.20)\end{array}$ & $\begin{array}{l}-0.001 \\
(-0.04)\end{array}$ & $\begin{array}{l}0.014 \\
(1.49)\end{array}$ & $\begin{array}{l}0.010 \\
(0.85)\end{array}$ & $\begin{array}{l}0.003 \\
(0.28)\end{array}$ & $\begin{array}{l}0.005 \\
(0.28)\end{array}$ & $\begin{array}{l}0.005 \\
(0.51)\end{array}$ \\
\hline State_Bank $\left(\gamma_{9}\right)$ & $\begin{array}{l}-0.131 \\
(-0.48)\end{array}$ & $\begin{array}{l}-0.279 \\
(-0.72)\end{array}$ & $\begin{array}{l}0.013 \\
(0.03)\end{array}$ & $\begin{array}{l}0.514 \\
(0.76)\end{array}$ & $\begin{array}{l}-0.381 \\
(-0.60)\end{array}$ & $\begin{array}{l}0.176 \\
(0.41)\end{array}$ & $\begin{array}{l}-0.228 \\
(-0.46)\end{array}$ & $\begin{array}{l}0.296 \\
(0.43)\end{array}$ & $\begin{array}{l}-0.373 \\
(-0.64)\end{array}$ & $\begin{array}{l}-0.149 \\
(-0.31)\end{array}$ \\
\hline Foreign_Bank $\left(\gamma_{10}\right)$ & $\begin{array}{c}-0.515^{* *} \\
(-2.27)\end{array}$ & $\begin{array}{c}-0.823^{* *} \\
(-1.99)\end{array}$ & $\begin{array}{l}-0.448 \\
(-1.10)\end{array}$ & $\begin{array}{l}1.792 \\
(1.33)\end{array}$ & $\begin{array}{l}0.156 \\
(0.18)\end{array}$ & $\begin{array}{l}-0.010 \\
(-0.03)\end{array}$ & $\begin{array}{l}-0.670 \\
(-1.32)\end{array}$ & $\begin{array}{l}-0.436 \\
(-0.96)\end{array}$ & $\begin{array}{c}-1.767 * * * \\
(-2.85)\end{array}$ & $\begin{array}{l}0.150 \\
(0.34)\end{array}$ \\
\hline Subsidiary $\left(\gamma_{11}\right)$ & $\begin{array}{l}0.045 \\
(0.22)\end{array}$ & $\begin{array}{c}-1.102 * * * \\
(-3.74)\end{array}$ & $\begin{array}{c}-1.037 * * * * \\
(-4.91)\end{array}$ & $\begin{array}{l}1.637 * \\
(1.79)\end{array}$ & $\begin{array}{l}-0.462 \\
(-0.89)\end{array}$ & $\begin{array}{l}0.624 * \\
(1.84)\end{array}$ & $\begin{array}{l}-0.408 \\
(-0.81)\end{array}$ & $\begin{array}{c}-0.665 \text { *** } \\
(-2.20)\end{array}$ & $\begin{array}{c}-1.280^{* *} \\
(-2.41)\end{array}$ & $\begin{array}{c}-0.837 * * * * \\
(-2.69)\end{array}$ \\
\hline Young_Bank $\left(\gamma_{12}\right)$ & $\begin{array}{l}0.393 \\
(0.59)\end{array}$ & $\begin{array}{l}0.399 \\
(0.56)\end{array}$ & $\begin{array}{c}0.646^{*} \\
(1.67)\end{array}$ & $\begin{array}{l}1.561 \\
(1.22)\end{array}$ & $\begin{array}{l}1.333 \\
(1.63)\end{array}$ & $\begin{array}{l}-0.436 \\
(-0.78)\end{array}$ & $\begin{array}{l}-0.789 \\
(-1.07)\end{array}$ & $\begin{array}{l}0.982 \\
(0.93)\end{array}$ & $\begin{array}{l}-0.684 \\
(-0.45)\end{array}$ & $\begin{array}{l}1.933 \\
(1.24)\end{array}$ \\
\hline Middle_Aged_Bank $\left(\gamma_{13}\right)$ & $\begin{array}{l}0.559 \\
(1.50)\end{array}$ & $\begin{array}{l}0.835^{*} \\
(1.86)\end{array}$ & $\begin{array}{l}0.605^{*} \\
(1.95)\end{array}$ & $\begin{array}{l}1.617 * * \\
(2.41)\end{array}$ & $\begin{array}{l}1.184 * * * \\
(3.05)\end{array}$ & $\begin{array}{l}0.364 \\
(0.80)\end{array}$ & $\begin{array}{l}1.347 \\
(1.55)\end{array}$ & $\begin{array}{l}0.083 \\
(0.22)\end{array}$ & $\begin{array}{l}0.296 \\
(0.55)\end{array}$ & $\begin{array}{l}0.386 \\
(0.96)\end{array}$ \\
\hline Domestic_Interest_Rate $\left(\gamma_{15}\right)$ & $\begin{array}{l}0.027 \\
(1.16)\end{array}$ & $\begin{array}{l}0.162 * * * \\
(6.92)\end{array}$ & $\begin{array}{l}0.098 * * * \\
(5.65)\end{array}$ & $\begin{array}{l}0.120^{*} \\
(1.70)\end{array}$ & $\begin{array}{l}0.101 * * \\
(2.17)\end{array}$ & $\begin{array}{l}-0.010 \\
(-0.10)\end{array}$ & $\begin{array}{c}0.676 * * * \\
(4.33)\end{array}$ & $\begin{array}{l}0.625 * * * \\
(4.23)\end{array}$ & $\begin{array}{c}0.389 * \\
(1.91)\end{array}$ & $\begin{array}{l}0.636 * * * \\
(3.01)\end{array}$ \\
\hline $\begin{array}{l}\text { Islamic_Bank } \times \\
\text { Domestic_Interest_Rate }\left(\gamma_{\mathrm{ID}}\right)\end{array}$ & $\begin{array}{l}-0.014 \\
(-0.32)\end{array}$ & $\begin{array}{l}-0.076 \\
(-1.21)\end{array}$ & $\begin{array}{l}-0.016 \\
(-0.29)\end{array}$ & $\begin{array}{l}-0.127 \\
(-1.26)\end{array}$ & $\begin{array}{c}-0.141 \text { ** } \\
(-2.29)\end{array}$ & $\begin{array}{c}-0.211 * * \\
(-2.07)\end{array}$ & $\begin{array}{c}-0.345^{* * * *} \\
(-2.61)\end{array}$ & $\begin{array}{l}-0.094 \\
(-0.63)\end{array}$ & $\begin{array}{c}-0.377^{* *} \\
(-2.29)\end{array}$ & $\begin{array}{c}-0.271 * * \\
(-2.03)\end{array}$ \\
\hline $\mathrm{HHI}\left(\gamma_{16}\right)$ & $\begin{array}{l}-0.726 \\
(-0.60)\end{array}$ & $\begin{array}{l}-1.951 \\
(-1.22)\end{array}$ & $\begin{array}{l}0.122 \\
(0.12)\end{array}$ & $\begin{array}{l}0.756 \\
(0.20)\end{array}$ & $\begin{array}{l}-2.154 \\
(-1.17)\end{array}$ & $\begin{array}{l}0.245 \\
(0.08)\end{array}$ & $\begin{array}{c}10.855^{*} \\
(1.83)\end{array}$ & $\begin{array}{l}9.682^{*} \\
(1.74)\end{array}$ & $\begin{array}{l}-5.170 \\
(-0.48)\end{array}$ & $\begin{array}{l}0.772 \\
(0.11)\end{array}$ \\
\hline GDP_Per_Capita $\left(\gamma_{17}\right)$ & $\begin{array}{l}0.012 \\
(0.37)\end{array}$ & $\begin{array}{l}0.106^{* * * *} \\
(2.88)\end{array}$ & $\begin{array}{c}0.118 * * * \\
(2.65)\end{array}$ & $\begin{array}{l}0.180^{*} \\
(1.80)\end{array}$ & $\begin{array}{l}0.237 * * * \\
(2.84)\end{array}$ & $\begin{array}{l}-0.005 \\
(-0.06)\end{array}$ & $\begin{array}{l}0.190 \\
(1.57)\end{array}$ & $\begin{array}{l}0.142 \\
(1.40)\end{array}$ & $\begin{array}{l}-0.136 \\
(-0.53)\end{array}$ & $\begin{array}{l}-0.046 \\
(-0.28)\end{array}$ \\
\hline GDP_Per_Capita_Growth $\left(\gamma_{18}\right)$ & $\begin{array}{l}-0.026 \\
(-1.09)\end{array}$ & $\begin{array}{l}0.013 \\
(0.36)\end{array}$ & $\begin{array}{l}0.071 \\
(1.45)\end{array}$ & $\begin{array}{l}-0.017 \\
(-0.40)\end{array}$ & $\begin{array}{l}-0.025 \\
(-0.99)\end{array}$ & $\begin{array}{l}0.026 \\
(0.81)\end{array}$ & $\begin{array}{l}0.109 \\
(1.53)\end{array}$ & $\begin{array}{l}0.106 \\
(1.27)\end{array}$ & $\begin{array}{c}0.188^{* *} \\
(2.00)\end{array}$ & $\begin{array}{l}0.196^{*} \\
(1.91)\end{array}$ \\
\hline Constant $\left(\gamma_{0}\right)$ & $\begin{array}{c}4.760 * * * * \\
(4.68)\end{array}$ & $\begin{array}{c}7.877 * * * \\
(5.77)\end{array}$ & $\begin{array}{c}0.000 \\
(.)\end{array}$ & $\begin{array}{c}5.835^{* * *} \\
(1.97)\end{array}$ & $\begin{array}{l}0.613 \\
(0.35)\end{array}$ & $\begin{array}{l}-0.204 \\
(-0.05)\end{array}$ & $\begin{array}{c}-23.974 * * \\
(-2.55)\end{array}$ & $\begin{array}{c}0.000 \\
(.)\end{array}$ & $\begin{array}{l}-9.910 \\
(-1.03)\end{array}$ & $\begin{array}{c}-22.785 * * \\
(-2.35)\end{array}$ \\
\hline $\begin{array}{l}\text { Number of Obs } \\
\text { R-squared }\end{array}$ & $\begin{array}{l}1,036 \\
0.524\end{array}$ & $\begin{array}{l}1,030 \\
0.640\end{array}$ & $\begin{array}{l}1,014 \\
0.530\end{array}$ & $\begin{array}{c}333 \\
0.583\end{array}$ & $\begin{array}{c}290 \\
0.751\end{array}$ & $\begin{array}{c}471 \\
0.421\end{array}$ & $\begin{array}{c}471 \\
0.538\end{array}$ & $\begin{array}{c}463 \\
0.573\end{array}$ & $\begin{array}{c}382 \\
0.621\end{array}$ & $\begin{array}{c}353 \\
0.672\end{array}$ \\
\hline $\begin{array}{l}\mathrm{H}_{0}: \gamma_{15}=\gamma_{\mathrm{ID}}=0 \text { (F-stat.) } \\
\mathrm{H}_{0}: \gamma_{15}+\gamma_{\mathrm{ID}}=0 \text { (F-stat.) }\end{array}$ & $\begin{array}{l}1.44 \\
0.07\end{array}$ & $\begin{array}{l}49.53 * * * \\
1.65\end{array}$ & $\begin{array}{c}34.14 * * * \\
1.67\end{array}$ & $\begin{array}{l}4.06 \\
0.00\end{array}$ & $\begin{array}{c}10.72 * * * \\
0.25\end{array}$ & $\begin{array}{l}4.78 * \\
3.44 *\end{array}$ & $\begin{array}{c}22.88^{* * * *} \\
3.00^{*}\end{array}$ & $\begin{array}{c}17.93^{* * * *} \\
7.55^{* * * *}\end{array}$ & $\begin{array}{c}7.75^{* *} \\
0.00\end{array}$ & $\begin{array}{c}13.37 * * * \\
2.10\end{array}$ \\
\hline
\end{tabular}

Dependent Variables: Net_Interest_Margin = (Interest Income - Interest Expense) / Average Earning assets, Interest_Income Rate $=$ Interest income divided by average earning assets for conventional banks and mark-up income over average earning assets for Islamic banks, Interest_Expense_Rate = Interest expense divided by average interest bearing liabilities and profit payouts over average profit bearing liabilities for Islamic banks, Loan_Rate = Interest income on loans divided by average gross lending for conventional banks and mark-up income on lending divided by average gross loans for Islamic banks, Deposit_Rate $=$ Interest expense on customer deposit divided by average customer deposits for conventional banks and profit payouts on customer deposits divided by average customer deposits for Islamic banks.

Explanatory Variables: Islamic_Bank $=$ Islamic bank dummy, Islamic_Window_Bank $=$ Islamic window bank dummy, Size $=$ Logarithm of total assets, Market_Share $=$ Logarithm of market share of total assets, orthogonalized on Size, Capital_Asset_Ratio $=$ The ratio of equity capital on total assets, Noninterest_Income $=$ Share of non-interest income in total operating income, Cost_Inefficiency $=$ Cost to income ratio, Loan_Loss_Reserve $=$ Loan loss reserves on gross loans ratio, State_Bank $=$ State-owned bank dummy, Foreign_Bank $=$ Foreign-owned bank dummy, Subsidiary = Subsidiary dummy, Young_Bank = Young bank dummy, Middle_Aged_Bank = Middle-aged bank dummy, Domestic_Interest_Rate $=$ Domestic interest rate, Islamic_Bank $\times$ Domestic_Interest_Rate $=$ Interaction term of Islamic_Bank and Domestic_Interest_Rate, HHI $=$ Hirschman-Herfindahl index, GDP_Per_Capita $=$ GDP per capita, GDP_Per_Capita_Growth $=$ Annual growth rate of GDP_Per_Capita

In columns (1) to (5), we estimate the model using Net_Interest_Margin, Interest_Income_Rate, Interest_Expense_Rate, Loan_Rate and Deposit_Rate as the dependent variables respectively for the pre-crisis period (2003-2007). In columns (6) to (10), we estimate the model for the crisis period (2008-2009).

We apply random effect technique with robust standard errors for our estimations. All the accounting and macro level variables are lagged for one period. Year and country dummies are included in the model, but not reported in the table. Robust z-statistics are reported in parentheses. $* * *, * *$ and $*$ indicate significance at $1 \%, 5 \%$ and $10 \%$ respectively. 


\section{References}

Abdul-Majid, M., Saal, D.S. and Battisti, G. (2010) Efficiency in Islamic and conventional banking: An international comparison, Journal of Productivity Analysis 34, 25-43.

Accounting and Auditing Organization for the Islamic Financial Institutions "AAOIFI" (1999) Accounting, Auditing and Governance Standards for Islamic Financial Institutions, Bahrain.

Aggarwal, R.K. and Yousef, T. (2000) Islamic banks and investment financing, Journal of Money, Credit and Banking 32, 93-120.

Ahmad, A. (1993) Contemporary practices of Islamic financing techniques, Research Paper No. 20, IRTI, Islamic Development Bank, Jeddah.

Al-Jarrah, I. and Molyneux, P. (2005) Efficiency in Arabian banking, in: M. Iqbal and R. Wilson (eds.), Islamic Perspectives on Wealth Creation, Edinburgh University Press, Edinburgh.

Alessandri, P. and Drehmann, M. (2010) An economic capital model integrating credit and interest rate risk in the banking book, Journal of Banking \& Finance 34, 730742.

Altunbas, Y., Evans, L. and Molyneux, P. (2001) Ownership and efficiency in banking, Journal of Money, Credit and Banking 33, 926-954.

Altunbas, Y., Carbo, S., Gardener, E.P.M. and Molyneux, P. (2007) Examining the relationships between capital, risk and efficiency in European banking, European Financial Management 13, 49-70.

Angbazo, L. (1997) Commercial bank net interest margins, defaults risk, interest-rate risk, and off-balance sheet banking, Journal of Banking \& Finance 21, 55-87.

Bader, M. K. I., Mohamad, S., Ariff, M. and Hassan, T. (2008) Cost, revenue and profit efficiency of Islamic versus conventional banks: International evidence using Data Envelopment Analysis, Islamic Economic Studies 15, 23-76.

Baele, L., Farooq, M. and Ongena, S. (2010) Of religion and redemption: Evidence from default on Islamic loans, CentER Discussion Paper Series No. 2010-136; European Banking Center Discussion Paper No. 2010-32. Available at SSRN: http://ssrn.com/abstract $=1740452$ or doi:10.2139/ssrn. 1740452

Bank Indonesia Report (2009) The lack of profit-and-loss sharing financing in Indonesia's Islamic banks: Revisited, Center of Education and Central Banking Studies, Bank Indonesia, Jakarta, Indonesia.

Bank for International Settlements (2010) 80th Annual Report, June, Basel.

Barry, T.A, Lepetit, L. and Tarazi, A. (2011) Ownership structure and risk in publicly held and privately owned banks, Journal of Banking \& Finance 35, 1327-1340.

Bashir, A. (1999) Risk and profitability measures in Islamic banks: The case of two Sudanese banks, Islamic Economic Studies 6, 1-24.

Beck T., Demirgüç-Kunt, A. and Merrouche, O. (2010) Islamic vs. conventional banking: Business model, efficiency and stability, World Bank Policy Research Working Paper Series No. 5446, Washington D.C., the World Bank.

Berger, A. (1995) The relationship between capital and earnings in banking, Journal of Money, Credit, and Banking 27, 432-456. 
Berger, A. and Udell, G. (2004) The institutional memory hypothesis and the procyclicality of bank lending behaviour, Journal of Financial Intermediation 13, 458-495.

Berger, A., Hasan, I. and Zhou, M. (2009) Bank ownership and efficiency in China: What will happen in the world's largest nation?, Journal of Banking \& Finance 33, 113130.

Bonin, J.P., Hasan, I., Wachtel, P. (2005) Bank performance, efficiency and ownership in transition countries, Journal of Banking \& Finance 29, 31-53.

Borio, C. and Zhu, H. (2008) Capital regulation, risk-taking and monetary policy: A missing link in the transmission mechanism?, Bank for International Settlements Working Paper No. 268.

Boyd, J. H. and Runkle, D.E. (1993) Size and performance of banking firms, Journal of Monetary Economics 31, 47-67.

Calomiris, C.W. and Kahn, C.M. (1991) The role of demandable debt in structuring optimal banking arrangements, American Economic Review 81, 497-513.

Carbo, S. and Rodriguez, F. (2007) The determinants of bank margins in European banking, Journal of Banking \& Finance 31, 2043-2063.

Carling, K., Jacobson, T., Linde, J. and Roszbach, K. (2007) Corporate credit risk modeling and the macroeconomy, Journal of Banking \& Finance 31, 845-868.

Cebenoyan, S.A. and Strahan, P.E. (2004) Risk management, capital structure and lending at banks, Journal of Banking \& Finance 28, 19-43.

Chong, B.S. and Liu, M.H. (2009) Islamic banking: Interest-free or interest-based?, Journal of Pacific-Basin Finance 17, 125-144.

Čihák, M. and Hesse, H. (2010) Islamic banks and financial stability: An empirical analysis, Journal of Financial Services Research 38, 95-113.

Čihák, M., Maechler, A., Schaeck, K. and Stolz, S. (2009) Who disciplines bank managers?, IMF Working Paper No. WP/09/272, Washington D.C., I.M.F.

Clair, R. (1992) Loan growth and loan quality: Some preliminary evidence from Texas banks, Federal Reserve Bank of Dallas Economic Review, 3rd quarter, 9-22.

Dar, H. A. and Presley, J. R. (2000) Lack of profit loss sharing in Islamic banking: Management and control imbalances, International Journal of Islamic Financial Services 2, No.2.

Delis, M.D. and Kouretas, G.P. (2011) Interest rates and bank risk-taking, Journal of Banking \& Finance 35, 840-855.

Dell'Ariccia, G. and Marquez, R. (2006) Lending booms and lending standards, The Journal of Finance 61, 2511-2546.

Demirguc-Kunt, A., Karacaovali, B. and Laeven, L. (2005) Deposit insurance around the World: A comprehensive database, World Bank Policy Working Paper No. 3628, Washington D.C., the World Bank.

DeYoung, R., Hunter, W.C. and Udell, G.F. (2004) The past, present, and probable future for community banks, Journal of Financial Services Research 25, 85-133.

DeYoung R. and Roland, K. P. (2001) Product mix and earnings volatility at commercial banks: Evidence from a degree of total leverage model, Journal of Financial Intermediation 10, 54-84.

Diamond, D.W. and Rajan, R.G. (2000) A theory of bank capital, The Journal of Finance 55, 2431-2465. 
Diamond, D.W. and Rajan, R.G. (2001) Liquidity risk, liquidity creation and financial fragility: A theory of banking, Journal of Political Economy 109, 287-327.

Drehmann, M., Sorensen, S. and Stringa, M. (2010) The integrated impact of credit and interest rate risk on banks: A dynamic framework and stress testing application, Journal of Banking \& Finance 34, 735-751.

El-Gamal, M., and Inanoglu, H. (2002) Efficiencies and unobserved heterogeneity in Turkish banking: 1990-2000, unpublished working paper, Rice University, Department of Economics.

Errico, L. and Farrahbaksh, M. (1998) Islamic banking: Issues in prudential regulation and supervision, IMF Working Paper No. 98/30.

Financial Times (2011) Islamic Finance Special Report, 12 May.

Foos, D., Norden, L. and Weber, M. (2010) Loan Growth and riskiness of banks, Journal of Banking \& Finance 34, 2929-2940.

Forssbæck, J. (2011) Ownership structure, market discipline, and banks' risk-taking incentives under deposit insurance, Journal of Banking \& Finance 35, 2666-2678.

Goddard, J.A, Molyneux, P, and Wilson J.O.S. (2004) Dynamics of growth and profitability in banking, Journal of Money, Credit and Banking 36, 1069-1090.

Gonzalez, F. (2005) Bank regulation and risk taking incentives: An international comparison of bank risk, Journal of Banking \& Finance 29, 1153-1184.

Goyeau, D. and Tarazi, A. (1992) Evaluation du risque de de'faillance bancaire en Europe, Revue d'Economie Politique 102, 249-280.

Hassan, M.K. and Bashir, A. (2003) Determinants of Islamic banking profitability, paper presented at the ERF Tenth Annual Conference, Marrakesh, Morocco, 16-18 December.

Hassan, M. and Dridi, J. (2010) The effects of the global crisis on Islamic and conventional banks: A comparative study, IMF Working Paper No. 10/201, Washington D.C., I.M.F.

Hesse, H. and Čihák, M. (2007) Cooperative banks and financial stability, IMF Working Paper No. 07/02, Washington D.C., I.M.F.

Hilary, G. and Hui, K. W. (2009) Does religion matter in corporate decision making in America?, Journal of Financial Economics 93, 455-473.

Hughes, J.P., Mester, L. and Moon, C. (2001) Are scale economies in banking elusive or illusive: Evidence obtained by incorporating capital structure and risk-taking into models of bank production, Journal of Banking \& Finance 25, 2169-2208.

Iannota, G., Giacomo, N. and Sironi, A. (2007) Ownership structure, risk and performance in the European banking industry, Journal of Banking \& Finance 31, 2127-2149.

Imam, P. and Kpodar, K. (2010) Islamic banking: How has it diffused?, IMF Working Paper No. 10/195, Washington D.C., I.M.F.

Iqbal, M., Ausaf, A. and Khan, T. (1998) Challenges facing Islamic banking, Occasional Paper No. 1, IRTI, Islamic Development Bank, Jeddah.

Iqbal, Z. and Mirakhor, A. (2007) An introduction to Islamic finance: Theory and practice, Wiley, London, ISBN 0470821884.

Jarrow, R.A. and Turnbull, S.M. (2000) The intersection of market and credit risk, Journal of Banking \& Finance 24, 271-299. 
Jeanne, O. (2000) Debt maturity and the global financial architecture, Discussion Paper No. 2520, Centre for Economic Policy Research, London.

Kahf, M. and Khan, T. (1992) Principles of Islamic financing, Research Paper No. 16, IRTI, Islamic Development Bank, Jeddah.

Kane, E. (2010) Redefining and containing systemic risk, Atlantic Economic Journal 38, 251-264.

Khan, F. (1991) Comparative economics of some Islamic financing techniques, Research Paper No. 12, IRTI, Islamic Development Bank, Jeddah.

Khan, T. and Ahmed, H. (2001) Risk management: An analysis of issues in Islamic financial industry, Occasional Paper No. 5, IRTI, Islamic Development Bank, Jeddah.

Konishi, M. and Yasuda, Y. (2004) Factors affecting bank risk taking: Evidence from Japan, Journal of Banking \& Finance 28, 215-232.

Kwan, S. and Eisenbeis, R. (1997) Bank risk, capitalization and operating efficiency, Journal of Financial Services Research 12, 117-31.

Laeven, L. and Levine, R. (2009) Bank governance, regulation and risk taking, Journal of Financial Economics 93, 259-275.

La Porta, R., Lopez-de-Silanes, F. and Shleifer, A. (2002) Government ownership of banks, The Journal of Finance 57, 265-301.

Lepetit, L., Nys, E., Rous, P. and Tarazi, A. (2008a) Bank income structure and risk: An empirical analysis of European banks, Journal of Banking \& Finance 32, 1452-1467.

Lepetit, L., Nys, E., Rous, P. and Tarazi, A. (2008b) The expansion of services in European banking: Implications for loan pricing and interest margins, Journal of Banking \& Finance 32, 2325-2335.

Maddaloni, A. and Peydró, J. (2011) Bank risk-taking, securitization, supervision, and low interest rates: Evidence from the Euro area and U.S. lending standards, Review of Financial Studies 24, 2121-65.

Majid, A. M, Nor, N.G. and Said, F.F. (2003) Efficiency of Islamic banks in Malaysia, Paper presented to the Fifth International Conference on Islamic Economics and Banking, Bahrain, October, 7-9, 2003.

Maudos, J. and Fernandez de Guevara, J.F. (2004) Factors explaining the interest margin in the banking sectors of the European Union, Journal of Banking \& Finance 28, 2259-2281.

Miller, A. and Hoffmann, J. (1995) Risk and religion: An explanation of gender differences in religiosity, Journal for the Scientific Study of Religion 34, 63-75.

Mills, P. S. and Presley, J.R. (1999) Islamic finance: Theory and practice, Macmillan, London.

Mohamad, S., Hassan, T. and Bader, M.K.I. (2008) Efficiency of conventional versus Islamic banks: International evidence using the stochastic frontier approach (SFA), Journal of Islamic Economics, Banking and Finance 4, 107-130.

Osoba, B. (2003) Risk preferences and the practice of religion: Evidence from panel data, Unpublished Working Paper, West Virginia University.

Obaidullah, M. (2005) Islamic financial services, Islamic Economics Research Center, King Abdulaziz University, Jeddah, Saudi Arabia.

Ogura, Y. (2006) Learning from a rival bank and lending boom, Journal of Financial Intermediation 15, 535-555. 
Ongena, S. and Şendeniz-Yüncü, İ. (2011) Which firms engage small, foreign, or state banks? And who goes Islamic? Evidence from Turkey, Journal of Banking \& Finance 35, 3213-3224.

Rajan, R.G. (2006) Has finance made the world riskier?, European Financial Management 12, 499-533.

Rashwan, M. H. (2010) A comparison between Islamic and traditional banks: Pre and post the 2008 financial crisis, Available at SSRN: http://ssrn.com/abstract=1724451 or doi:10.2139/ssrn.1724451.

Samad, A. (1999) Comparative efficiency of the Islamic bank vis-à-vis conventional banks in Malaysia, IIUM Journal of Economics and Management 7, 1-25.

Shiers A.F. (2002) Branch banking, economic diversity and bank risk, The Quarterly Review of Economics and Finance 42, 587-598.

Stiroh, K. (2004) Diversification in banking: Is non-interest income the answer?, Journal of Money, Credit and Banking 36, 853-882.

Stiroh, K. (2006) A portfolio view of banking with interest and noninterest activities, Journal of Money, Credit and Banking 38, 1351-1361.

Stiroh, K. (2010) Diversification in banking, Chapter 6 in: A. Berger, P. Molyneux and J.O.S. Wilson (eds.) Oxford Handbook of Banking, Oxford: Oxford University Press, pp. 146-170.

Sundararajan, V. and Errico, L. (2002) Islamic financial institutions and products in the global financial system: Key issues in risk management and challenges ahead, IMF Working Paper No. WP/02/192, Washington D.C., I.M.F.

Taboada, A.G. (2011) The impact of changes in bank ownership structure on the allocation of capital: International evidence, Journal of Banking \& Finance 35, 25282543.

TheCityUK (2011) Islamic Finance, Financial Market Series, May, London:TheCityUK.

The World Factbook (2009) Washington, DC: Central Intelligence Agency, 2009.

Weill, L. (2011) Do Islamic banks have greater market power?, Comparative Economic Studies 53, 291-306.

Wong, K. (1997) On the determinants of bank interest margins under credit and interest rate risks, Journal of Banking \& Finance 21, 251-271.

Yudistra. D. (2004) Efficiency in Islamic banking: An empirical analysis of eighteen banks, Islamic Economic Studies 12, 1-19. 
Table I. Existing Literature

This table presents a summary of selected empirical literature on Islamic banking.

\begin{tabular}{|c|c|c|c|c|c|c|}
\hline Authors & Country(ies) of Study & Period & Data Type & Research Focus & Methodology & Main Finding \\
\hline Bashir (1999) & Sudan & 1979-1993 & $\begin{array}{l}\text { Yearly bank-level } \\
\text { accounting data }\end{array}$ & $\begin{array}{l}\text { Asset size and bank } \\
\text { performance }\end{array}$ & Regression - OLS & $\begin{array}{l}\text { Larger banks are more profitable yet have higher leverage. Analysis is based on } \\
\text { only two Islamic banks. }\end{array}$ \\
\hline Samad (1999) & Malaysia & 1992-1996 & $\begin{array}{l}\text { Yearly bank-level } \\
\text { accounting data }\end{array}$ & Cost efficiency & $\begin{array}{l}\text { Descriptive statistics } \\
\text { and ANOVA }\end{array}$ & Islamic banks are more efficient than their conventional counterparts. \\
\hline $\begin{array}{l}\text { El-Gamal and } \\
\text { Inanoglu (2002) }\end{array}$ & Turkey & 1990-2000 & $\begin{array}{l}\text { Yearly bank level } \\
\text { accounting data }\end{array}$ & Production technology & $\begin{array}{l}\text { Stochastic Frontier } \\
\text { Analysis }\end{array}$ & $\begin{array}{l}\text { Islamic banks have a similar production technology to conventional commercial } \\
\text { banks. }\end{array}$ \\
\hline Majid et al (2003) & Malaysia & 1993-2000 & $\begin{array}{l}\text { Yearly bank level } \\
\text { accounting data }\end{array}$ & Cost efficiency & $\begin{array}{l}\text { Stochastic Frontier } \\
\text { Analysis }\end{array}$ & $\begin{array}{l}\text { No statistically significant difference in the level of efficiency between Islamic } \\
\text { and conventional banks and no evidence to suggest that ownership influences cost } \\
\text { efficiency. }\end{array}$ \\
\hline $\begin{array}{l}\text { Hassan and Bashir } \\
\text { (2003) }\end{array}$ & $\begin{array}{l}\text { Islamic banks operating } \\
\text { in } 21 \text { countries }\end{array}$ & $1994-2001$ & $\begin{array}{l}\text { Yearly bank level } \\
\text { accounting data }\end{array}$ & $\begin{array}{l}\text { Determinants of bank } \\
\text { profitability (ROA, } \\
\text { ROE, NIM) }\end{array}$ & Regression - GLS & $\begin{array}{l}\text { Controlling for macroeconomic environment, financial market structure, and } \\
\text { taxation, the results indicate that high capital and loan-to-asset ratios lead to } \\
\text { higher profitability (as does favourable macroeconomic conditions). }\end{array}$ \\
\hline Yudistra (2004) & $\begin{array}{l}\text { Islamic banks operating } \\
\text { in 12countries }\end{array}$ & 1997-2000 & $\begin{array}{l}\text { Yearly bank level } \\
\text { accounting data }\end{array}$ & $\begin{array}{l}\text { Technical and scale } \\
\text { efficiency }\end{array}$ & $\begin{array}{l}\text { Data Envelopment } \\
\text { Analysis (DEA) and } \\
\text { OLS regression }\end{array}$ & $\begin{array}{l}\text { Islamic bank inefficiencies appear relatively low (around } 10 \% \text { ) compared with } \\
\text { those for conventional banks derived from other studies. Small to medium-sized } \\
\text { Islamic banks exhibit diseconomies of scale. Islamic banks in the Middle East are } \\
\text { less efficient than those operating outside the region. }\end{array}$ \\
\hline $\begin{array}{l}\text { Al-Jarrah and } \\
\text { Molyneux (2005) }\end{array}$ & $\begin{array}{l}\text { Bahrian, Eqypt, Jordan } \\
\text { and Saudia Arabia }\end{array}$ & $1992-2000$ & $\begin{array}{l}\text { Yearly bank level } \\
\text { accounting data }\end{array}$ & $\begin{array}{l}\text { Cost and profit } \\
\text { efficiency }\end{array}$ & $\begin{array}{l}\text { Stochastic Frontier } \\
\text { Analysis }\end{array}$ & $\begin{array}{l}\text { Islamic banks are found to be the most cost and profit efficient banks compared to } \\
\text { conventional commercial and investment banks. }\end{array}$ \\
\hline Mohamad et al. (2008) & $\begin{array}{l}21 \text { Organization of } \\
\text { Islamic Conference } \\
\text { (OIC) countries }\end{array}$ & 1990-2005 & $\begin{array}{l}\text { Yearly bank level } \\
\text { accounting data }\end{array}$ & $\begin{array}{l}\text { Cost and profit } \\
\text { efficiency }\end{array}$ & $\begin{array}{l}\text { Stochastic Frontier } \\
\text { Analysis }\end{array}$ & $\begin{array}{l}\text { No significant difference between cost and profit efficiency of conventional } \\
\text { versus Islamic banks, irrespective of size, age and geographical location Islamic } \\
\text { banks based in the Middle East and Turkey are more cost efficient than their } \\
\text { African counterparts. }\end{array}$ \\
\hline Bader et al. (2008) & 21 OIC countries & 1995-2005 & $\begin{array}{l}\text { Yearly bank level } \\
\text { accounting data }\end{array}$ & $\begin{array}{l}\text { Cost, revenue and } \\
\text { profit efficiency }\end{array}$ & $\begin{array}{l}\text { Data Envelopment } \\
\text { Analysis }\end{array}$ & $\begin{array}{l}\text { No significant difference between cost, revenue and profit efficiency of } \\
\text { conventional versus Islamic banks. Note this study uses the same sample as } \\
\text { Mohamed et al (2008). }\end{array}$ \\
\hline Chong and Liu (2009) & Malaysia & $\begin{array}{l}\text { 1995:04- } \\
\text { 2004:04 }\end{array}$ & $\begin{array}{l}\text { Monthly interest } \\
\text { rates (rates of } \\
\text { return for Islamic } \\
\text { banks) }\end{array}$ & $\begin{array}{l}\text { Causality relationship } \\
\text { between Islamic banks } \\
\text { deposits rates and } \\
\text { interest rates in } \\
\text { conventional banking. }\end{array}$ & Granger causality test & $\begin{array}{l}\text { Rates of return on the investment deposits of Islamic banks are closely related to } \\
\text { rates on conventional banks' deposits. }\end{array}$ \\
\hline $\begin{array}{l}\text { Abdul-Majid et al. } \\
\text { (2010) }\end{array}$ & 10 countries & 1996-2002 & $\begin{array}{l}\text { Yearly bank level } \\
\text { accounting data }\end{array}$ & $\begin{array}{l}\text { Returns to scale and } \\
\text { efficiency }\end{array}$ & $\begin{array}{l}\text { Parametric output } \\
\text { distance function }\end{array}$ & $\begin{array}{l}\text { Islamic banks are found to have moderately higher returns to scale than } \\
\text { conventional banks but appear less efficient due to Sharia compliance. Country } \\
\text { effects have a significant impact on efficiency differences. }\end{array}$ \\
\hline $\begin{array}{l}\text { Baele, Farooq and } \\
\text { Ongena (2010) }\end{array}$ & Pakistan & $\begin{array}{l}2006: 04- \\
2008: 12\end{array}$ & $\begin{array}{l}\text { Monthly business } \\
\text { loans }\end{array}$ & Loan default rate & Hazard function & Default rates on Islamic loans are lower than for conventional loans. \\
\hline $\begin{array}{l}\text { Beck, Demirgüç-Kunt } \\
\text { and Merrouche (2010) }\end{array}$ & $\begin{array}{l}141 \text { countries } \\
\text { (including } 22 \text { OIC } \\
\text { member countries) }\end{array}$ & $\begin{array}{l}1995- \\
2007\end{array}$ & $\begin{array}{l}\text { Yearly bank-level } \\
\text { accounting data }\end{array}$ & $\begin{array}{l}\text { Efficiency, asset } \\
\text { quality, stability and } \\
\text { business orientation }\end{array}$ & $\begin{array}{l}\text { Regression - OLS } \\
\text { Fixed effects, Robust }\end{array}$ & Few significant differences are found between Islamic and conventional banks. \\
\hline $\begin{array}{l}\text { Čihák and Hesse } \\
\text { (2010) }\end{array}$ & $\begin{array}{l}20 \text { OIC member } \\
\text { countries }\end{array}$ & 1993-2004 & $\begin{array}{l}\text { Yearly bank-level } \\
\text { accounting data }\end{array}$ & Insolvency risk & $\begin{array}{l}\text { Regression - OLS and } \\
\text { Robust }\end{array}$ & $\begin{array}{l}\text { Small Islamic banks are more stable than small conventional banks; however, } \\
\text { large Islamic banks are less stable than their conventional counter-parts. }\end{array}$ \\
\hline
\end{tabular}




\begin{tabular}{|c|c|c|c|c|c|c|}
\hline $\begin{array}{l}\text { Imam and Kpodar } \\
\text { (2010) }\end{array}$ & 117 countries & $1992-2006$ & Country level data & $\begin{array}{l}\text { Determinants of the } \\
\text { diffusion of Islamic } \\
\text { banking }\end{array}$ & Regression - Tobit & $\begin{array}{l}\text { Probability for Islamic banking to develop in a country rises with the share of the } \\
\text { Muslim population, income per capita, and whether the country is a net exporter } \\
\text { of oil. Increasing interest rates limit the diffusion of Islamic banking. }\end{array}$ \\
\hline Rashwan (2010) & 15 countries & 2007-2009 & Bank level data & $\begin{array}{l}\text { Profitability and } \\
\text { efficiency over the } \\
\text { banking crisis }\end{array}$ & $\begin{array}{l}\text { Multivariate analysis of } \\
\text { variance (MANOVA) }\end{array}$ & $\begin{array}{l}\text { Islamic banks are more profitable and efficient than traditional banks pre-crisis } \\
\text { but the opposite is the case post-crisis. }\end{array}$ \\
\hline $\begin{array}{l}\text { Ongena and Şendeniz- } \\
\text { Yüncü (2010) }\end{array}$ & Turkey & 2008 & $\begin{array}{l}\text { Bank-firm } \\
\text { relationships }\end{array}$ & Firm bank choice & Multinomial logit & $\begin{array}{l}\text { Islamic banks mainly have corporate clients that are young, transparent, industry- } \\
\text { focused, and have multiple-bank relationships. }\end{array}$ \\
\hline $\begin{array}{l}\text { Hasan and Dridi } \\
\text { (2010) }\end{array}$ & 8 countries & 2007-2009 & $\begin{array}{l}\text { Yearly bank-level } \\
\text { accounting data }\end{array}$ & $\begin{array}{l}\text { Factors influencing } \\
\text { performance, growth } \\
\text { and ratings over crisis } \\
\text { period }\end{array}$ & Regression - OLS & $\begin{array}{l}\text { The credit and asset growth of Islamic banks was more than that of conventional } \\
\text { banks from } 2008 \text { to } 2009 \text { 'contributing to financial and economic stability', } \\
\text { although profits of Islamic banks fell more than conventional banks in } 2009 \text { due } \\
\text { to limitations in their risk management practices }\end{array}$ \\
\hline Weill (2011) & $\begin{array}{l}17 \text { OIC member } \\
\text { countries }\end{array}$ & $\begin{array}{l}2001- \\
2007\end{array}$ & $\begin{array}{l}\text { Yearly bank-level } \\
\text { accounting data }\end{array}$ & Market power & $\begin{array}{l}\text { Regression - random } \\
\text { effects GLS }\end{array}$ & Islamic banks have lower market power than conventional banks. \\
\hline This Paper & $\begin{array}{l}24 \text { OIC member } \\
\text { countries }\end{array}$ & 1999-2009 & $\begin{array}{l}\text { Yearly bank-level } \\
\text { accounting data }\end{array}$ & $\begin{array}{l}\text { Credit risk, insolvency } \\
\text { risk, interest rate risk } \\
\text { and possibility of } \\
\text { extracting religious rent }\end{array}$ & $\begin{array}{l}\text { Regression-random } \\
\text { effects }\end{array}$ & $\begin{array}{l}\text { Islamic banks that are small, leveraged or based in countries with predominantly } \\
\text { Muslim populations have lower credit risk than conventional banks. Small Islamic } \\
\text { banks appear more stable than similar sized conventional banks. During the recent } \\
\text { crisis, however, large Islamic banks exhibit lower stability than large conventional } \\
\text { banks. Implicit interest income and expense, as well as credit risk of Islamic } \\
\text { banks are less responsive to domestic interest rates. Islamic banks do not seem to } \\
\text { charge special rents to their clients for offering Shariá compliant financial } \\
\text { products. }\end{array}$ \\
\hline
\end{tabular}


Figure 1. Depositors' Payoff in Islamic and Conventional Banking

This figure illustrates the payoffs from investment account depositors in Islamic banking versus time depositors in conventional banking.

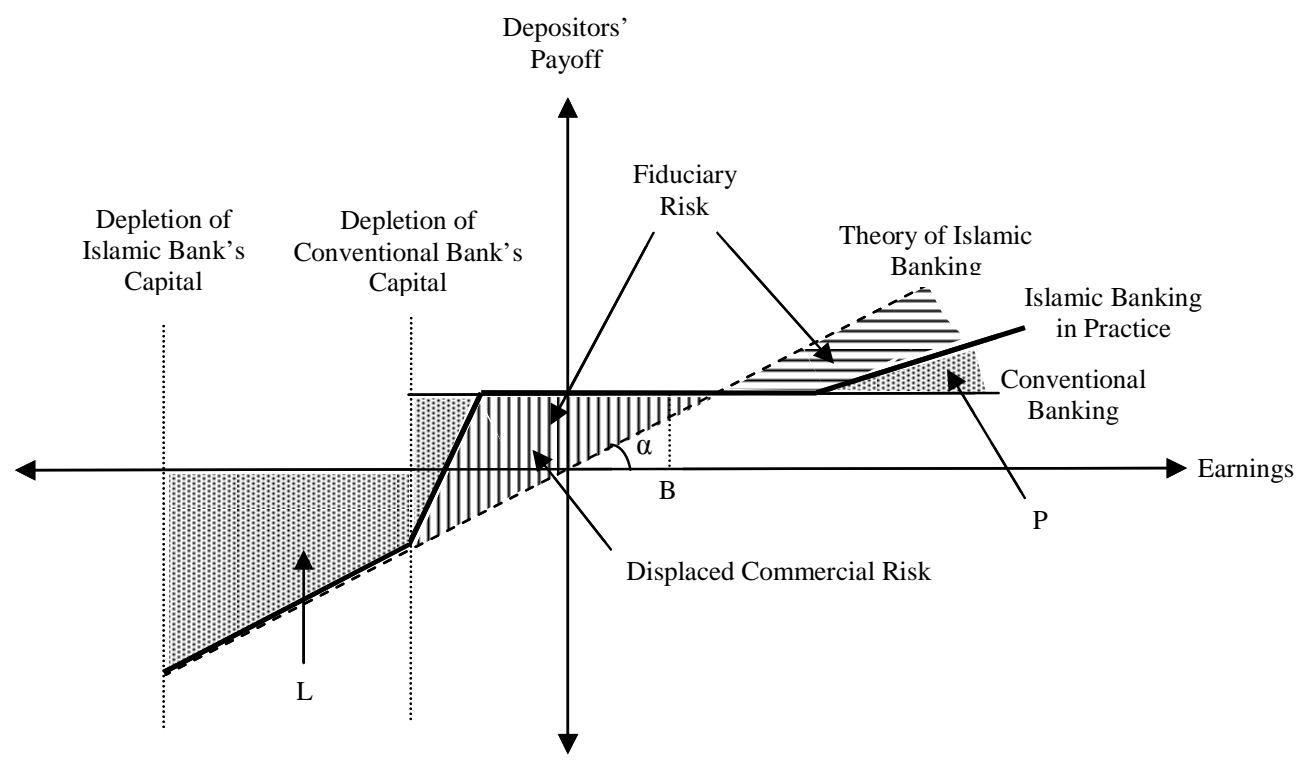

The horizontal axis represents a bank's earnings before paying interest expense. The vertical axis shows the interest expense to be paid to depositors (depositors' payoff). A conventional bank incurs loss for any earnings less than B, where the earnings equal to the interest expense. Depositors of conventional banks receive interest irrespective of the realized earnings, to the extent that the possible loss does not completely deplete the capital. Hence, the ex-post relationship between earnings and depositors' payoff is depicted by the horizontal line (earnings and depositors' payoffs are positively correlated in the ex-ante relationship, since depositors demand higher payoffs from banks with higher expected earnings, as they are expected to be more risky). The figure shows that the depletion occurs when earnings are negative; however, in reality depletion can happen when earnings are positive.

In theory, the realized profit or loss should be shared between depositors and equity-holders. The dashed line with a slope less than 45 degrees $(\alpha)$ shows that depositors payoff is proportionate to realized performance; however, in practice there is substantial evidence that Islamic banks pay a competitive rate of return, irrespective of actual performance. Also Islamic banks may adjust profit rates upward but at a slower rate than realized profitability so as to limit the level and volatility of deposit payoffs. At the time of crisis, however, Islamic banks may share the realized loss with investment account holders to avoid insolvency (the bold line is simply illustrative and does not necessarily show the real scale and magnitude of divergence from conventional depositors' payoffs). This suggests that Islamic banks may have a greater capacity to bear losses compared to conventional banks. The magnitude of the extra capacity (and hence the exact position of the vertical line that illustrates the capital depletion of a typical Islamic bank) depends on the weight of investment deposits in the total funding of the Islamic bank. Implicitly, investment account holders own a bond, a long position on a call option and a short position on a put option. The strike price of the call is determined arbitrarily by Islamic banks, and the strike price of the put is determined based on the degree of deposit market competition, level of incurred losses and capital strength. Overall, when Islamic banks are profitable investment account holders may get $\mathrm{P}$ over the depositor payoffs at conventional banks, at the expense of $\mathrm{L}$ in the case of a scenario where losses occur. Hence, in practice the difference between depositors' payoffs of Islamic versus conventional banks can appear mostly in the tails distribution of bank's earnings. Displaced commercial risk illustrates the situation where equity-holders have to transfer (or sacrifices) a part of their profit or incur a portion of depositors' loss to avoid deposits withdrawal. Fiduciary risk is the risk associated with Islamic banks deviating from Shariá principles in sharing returns between investment account holders and equity-holders. It may be that depositors do not have the relevant incentives or/and expertise to observe or take action against such deviations. 
Table II. Descriptive Statistics

General descriptive statistics and risk measure variables for Islamic, conventional and Islamic window banks over the 1999-2009 period.

\begin{tabular}{|c|c|c|c|c|c|c|c|c|c|c|c|c|c|c|c|c|c|}
\hline & \multirow[b]{2}{*}{ Variables } & \multicolumn{5}{|c|}{ Islamic Banks } & \multicolumn{5}{|c|}{ Conventional Banks } & \multirow[b]{2}{*}{ T-Stat. $\dagger$} & \multicolumn{5}{|c|}{ Islamic Window Banks } \\
\hline & & Number & Mean & SD & Min & $\operatorname{Max}$ & Number & Mean & SD & Min & $\operatorname{Max}$ & & Number & Mean & SD & Min & $\operatorname{Max}$ \\
\hline \multirow{3}{*}{ 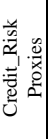 } & Loan_Loss_Reserve (\%) & 593 & 6.75 & 7.71 & 0.00 & 58.00 & 2,105 & 8.72 & 9.38 & 0.00 & 60.55 & $-5.23^{* * * *}$ & 561 & 7.82 & 7.62 & 0.00 & 51.67 \\
\hline & Impaired_Loans (\%) & 381 & 8.31 & 10.33 & 0.00 & 66.39 & 1,604 & 11.14 & 12.97 & 0.00 & 76.41 & $-4.55^{* * * *}$ & 467 & 10.23 & 10.97 & 0.00 & 67.93 \\
\hline & Loan_Loss_Provision (\%) & 574 & 1.35 & 3.10 & -22.20 & 26.00 & 1,982 & 1.70 & 3.18 & -22.52 & 30.69 & $-2.33^{* * *}$ & 537 & 1.65 & 3.06 & -4.30 & 30.70 \\
\hline \multirow{6}{*}{ 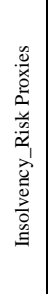 } & Zscore_rw & 388 & 3.42 & 1.31 & -0.74 & 8.59 & 1,349 & 3.48 & 1.30 & -1.32 & 8.72 & -0.83 & 392 & 3.54 & 1.36 & -1.45 & 9.39 \\
\hline & Zscore_P1_rw & 411 & 1.13 & 1.11 & -3.28 & 5.33 & 1,42 & 1.25 & 1.32 & -4.84 & 5.39 & $-1.88 *$ & 417 & 1.56 & 1.33 & -5.13 & 5.70 \\
\hline & Zscore_P2_rw & 389 & 3.28 & 1.37 & -0.50 & 8.55 & 1,367 & 3.31 & 1.36 & -1.31 & 8.70 & -0.42 & 395 & 3.37 & 1.36 & -0.44 & 9.25 \\
\hline & Zscore & 75 & 2.87 & 0.93 & 0.05 & 5.22 & 251 & 2.87 & 1.02 & -0.77 & 6.31 & 0.02 & 67 & 2.85 & 1.08 & -0.15 & 5.13 \\
\hline & Zscore_P1 & 70 & 0.53 & 0.75 & -2.40 & 2.04 & 226 & 0.65 & 0.91 & -2.53 & 2.62 & -1.15 & 60 & 0.95 & 0.92 & -1.60 & 2.86 \\
\hline & Zscore_P2 & 75 & 2.77 & 0.92 & 0.70 & 5.20 & 252 & 2.76 & 1.00 & 0.09 & 6.28 & 0.09 & 67 & 2.73 & 1.08 & -0.04 & 5.03 \\
\hline \multirow{5}{*}{ 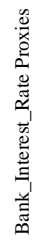 } & Net_Interest_Margin (\%) & 684 & 4.19 & 3.39 & -9.42 & 24.09 & 2,46 & 4.17 & 3.09 & -12.58 & 24.83 & 0.19 & 673 & 3.47 & 2.43 & -10.45 & 23.45 \\
\hline & Interest_Income_Rate (\%) & 623 & 8.02 & 4.38 & 0.01 & 38.70 & 2,351 & 9.81 & 4.84 & 0.09 & 39.07 & $-8.87^{* * * *}$ & 650 & 8.05 & 3.43 & 1.11 & 31.81 \\
\hline & Interest_Expense_Rate (\%) & 544 & 4.39 & 3.39 & 0.08 & 26.40 & 2,355 & 5.84 & 3.67 & 0.06 & 26.55 & $-8.80^{* * * *}$ & 649 & 4.65 & 2.59 & 0.30 & 19.41 \\
\hline & Loan_Rate $(\%)$ & 228 & 9.60 & 4.70 & 0.30 & 23.80 & 629 & 9.97 & 4.46 & 0.60 & 29.60 & -1.03 & 209 & 8.90 & 4.44 & 1.70 & 28.64 \\
\hline & Deposit_Rate (\%) & 188 & 5.02 & 3.75 & 0.10 & 16.50 & 588 & 4.81 & 3.07 & 0.10 & 15.30 & 0.68 & 180 & 4.27 & 2.46 & 0.80 & 11.80 \\
\hline \multirow{10}{*}{ 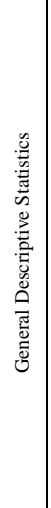 } & Total Assets (mil. \$) & 782 & 3,732 & 7,284 & 530 & 48,1 & 2,448 & 4,041 & 8,664 & 132 & 87,9 & -1 & 640 & 5,188 & 8,576 & 4,478 & 63 \\
\hline & Market_Share (\%) & 782 & 0.07 & 0.13 & 0.00 & 1.00 & 2,448 & 0.06 & 0.12 & 0.00 & 1.00 & $2.26^{* *}$ & 640 & 0.07 & 0.11 & 0.00 & 0.56 \\
\hline & Capital_Asset_Ratio (\%) & 750 & 17.10 & 16.12 & 0.43 & 87.01 & 2,403 & 13.38 & 11.07 & 0.01 & 86.93 & $5.90 * * *$ & 626 & 11.78 & 9.28 & 1.48 & 70.12 \\
\hline & ROAA $(\%)$ & 715 & 1.48 & 2.46 & -12.29 & 13.20 & 2,458 & 1.23 & 2.26 & -16.48 & 13.89 & $2.40^{* *}$ & 672 & 1.28 & 2.04 & -17.82 & 8.93 \\
\hline & ROAE $(\%)$ & 715 & 12.93 & 17.43 & -118.28 & 123.65 & 2,429 & 12.26 & 18.17 & -124.83 & 133.30 & 0.90 & 668 & 15.55 & 17.42 & -118.25 & 119.92 \\
\hline & $\begin{array}{l}\text { Loan_Total_Earning_Asset_Ratio } \\
(\%)\end{array}$ & 767 & 58.00 & 26.01 & 0.02 & 100.00 & 2,431 & 53.58 & 22.78 & 0.00 & 100.00 & $4.22^{* * *}$ & 637 & 57.12 & 20.43 & 0.00 & 100.00 \\
\hline & Loan_Growth (\%) & 685 & 29.59 & 51.33 & -100.00 & 351.73 & 2,047 & 21.67 & 40.31 & -100.00 & 325.28 & $3.68^{* * *}$ & 573 & 19.90 & 38.83 & -96.60 & 326.93 \\
\hline & Asset_Growth (\%) & 709 & 26.27 & 33.45 & -74.95 & 207.08 & 2,265 & 19.16 & 30.22 & -73.80 & 211.08 & $5.06^{* * *}$ & 596 & 18.68 & 27.97 & -62.00 & 177.60 \\
\hline & Noninterest_Income (\%) & 689 & 42.14 & 29.34 & -70.23 & 158.92 & 2,405 & 33.60 & 23.17 & -115.15 & 158.45 & $7.03 * * *$ & 668 & 33.33 & 19.89 & -20.96 & 149.22 \\
\hline & Cost_Inefficiency (\%) & 658 & 59.80 & 34.03 & 3.04 & 268.53 & 2,382 & 57.12 & 31.56 & 1.88 & 287.87 & $1.82^{*}$ & 661 & 48.08 & 21.69 & 3.93 & 180.00 \\
\hline
\end{tabular}

Credit_Risk Proxies: Loan_Loss_Reserve = Loan loss reserves on gross loans ratio, Impaired_Loans = Impaired loans on gross loans ratio, Loan_Loss_Provision = Loan loss provision on average gross loans ratio.

Insolvency_Risk Proxies: Zscore_rw $=$ Logarithm of rolling-window Zscore which is equal to $($ ROAA+Capital_Asset_Ratio $) / S D R O A A \_r w, S D R O A A \_r w=$ Standard deviation of $R O A A$ over 3 years (current year and two previous consecutive years). Banks need to have three consecutive observations. Acquiring banks are excluded from the sample, since the volatility on their assets returns can be due to the acquisition. Zscore P1 $r w=$ Logarithm of ROAA/SDROAA3 $r w, Z s c o r e P 2 \quad r w=$ Logarithm of Capital_Asset_Ratio/SDROAA3_rw, Zscore $=$ Logarithm of $\left(M_{-} R O A A+M_{-}\right.$Capital_Asset_Ratio $) / S D R O A A, M \_R O A A=$ Mean of ROAA over the sample period, $M_{-}$Capital_Asset_Ratio =Mean of Capital_Asset_Ratio over the sample period, SDROAA = standard deviation of ROAA over the sample period (banks needs to have at least four consecutive observations), Zscore_P1 = Logarithm of $M_{-}$ROAA/SDROAA, Zscore_P2 = Logarithm of $M_{-} E T A / S D R O A A$.

Bank_Interest_Rate Proxies: Net_Interest_Margin $=($ Interest Income - Interest Expense $) /$ Average Earning assets, Interest_Income_Rate $=$ Interest income divided by average earning assets for conventional banks and mark-up income over average earning assets for Islamic banks, Interest_Expense_Rate $=$ Interest expense divided by average interest bearing liabilities and profit payouts over average profit bearing liabilities for Islamic banks, Loan_Rate $=$ Interest income on loans divided by average gross lending for conventional banks and mark-up income on lending divided by average gross loans for Islamic banks, Deposit_Rate = Interest expense on customer deposit divided by average customer deposits for conventional banks and profit payouts on customer deposits divided by average customer deposits for Islamic banks.

General Descriptive Statistics: Total Assets $=$ Total assets in millions U.S.\$, Market_Share $=$ Market share of total assets, Capital_Asset_Ratio $=$ Equity capital to asset ratio, $R O A A=$ Return on average assets, ROAE = Return on average equity, Loan_Total_Earning_Asset_Ratio $=$ Share of net loans in total earning assets, Loan_Growth $=$ Annual growth rate of gross loans, Asset_Growth = Annual growth rate of total assets, Noninterest_Income $=$ Share of non-interest income in total operating income, Cost_Inefficiency $=$ Cost to income ratio.

$\dagger$ T-Stat. of Mean Equality Test between Islamic and conventional banks. ***, ** and * indicate significance at 1\%, 5\% and $10 \%$ respectively. 


\section{Table III. Credit Risk Model}

This table presents the estimation of the credit risk model. In columns (1) to (6), we investigate whether credit risk of Islamic banks is, on average, higher or lower than conventional banks. The final five columns investigate various interaction variables highlighting whether religious factors influence credit risk.

\begin{tabular}{|c|c|c|c|c|c|c|c|c|c|c|c|}
\hline Variables & (1) & (2) & (3) & (4) & (5) & (6) & (7) & (8) & (9) & (10) & (11) \\
\hline Islamic_Bank $\left(\alpha_{1}\right)$ & $\begin{array}{c}-2.300 * * * \\
(-2.98)\end{array}$ & $\begin{array}{l}-1.627 * \\
(-1.83)\end{array}$ & $\begin{array}{c}-2.088^{* * *} \\
(-2.23)\end{array}$ & $\begin{array}{c}-2.135 * * \\
(-2.28)\end{array}$ & $\begin{array}{c}-1.971 \text { ** } \\
(-2.03)\end{array}$ & $\begin{array}{c}-3.037 * * * * \\
(-2.79)\end{array}$ & $\begin{array}{l}8.200 \\
(1.55)\end{array}$ & $\begin{array}{l}0.985 \\
(0.67)\end{array}$ & $\begin{array}{l}-0.449 \\
(-0.29)\end{array}$ & $\begin{array}{c}-5.734 * * * \\
(-3.69)\end{array}$ & $\begin{array}{c}-14.560 * * \\
(-2.24)\end{array}$ \\
\hline Islamic_Window_Bank $\left(\alpha_{2}\right)$ & $\begin{array}{c}-2.035^{* *} \\
(-2.01)\end{array}$ & $\begin{array}{l}-0.791 \\
(-1.00)\end{array}$ & $\begin{array}{l}-0.894 \\
(-1.12)\end{array}$ & $\begin{array}{l}-0.890 \\
(-1.11)\end{array}$ & $\begin{array}{l}-0.441 \\
(-0.54)\end{array}$ & $\begin{array}{l}-1.213 \\
(-1.35)\end{array}$ & $\begin{array}{l}-0.579 \\
(-0.71)\end{array}$ & $\begin{array}{c}-1.541^{*} \\
(-1.84)\end{array}$ & $\begin{array}{l}-0.973 \\
(-1.08)\end{array}$ & $\begin{array}{l}-1.349 \\
(-1.49)\end{array}$ & $\begin{array}{l}-1.071 \\
(-1.18)\end{array}$ \\
\hline Size $\left(\alpha_{3}\right)$ & & $\begin{array}{c}-0.917 * * * \\
(-3.84)\end{array}$ & $\begin{array}{c}-0.896 * * * \\
(-3.72)\end{array}$ & $\begin{array}{c}-0.887 * * * \\
(-3.59)\end{array}$ & $\begin{array}{c}-0.860 * * * \\
(-3.29)\end{array}$ & $\begin{array}{c}-0.728 * * \\
(-2.15)\end{array}$ & $\begin{array}{c}-0.750 * * * \\
(-2.66)\end{array}$ & $\begin{array}{c}-0.764 * * * \\
(-2.73)\end{array}$ & $\begin{array}{c}-0.769^{* * *} \\
(-2.28)\end{array}$ & $\begin{array}{c}-0.823 * * * \\
(-2.63)\end{array}$ & $\begin{array}{c}-0.872^{* * *} \\
(-2.42)\end{array}$ \\
\hline Islamic_Bank $\times$ Size $\left(\alpha_{\text {IS }}\right)$ & & & & & & & & & & & $\begin{array}{c}0.839^{*} \\
(1.86)\end{array}$ \\
\hline Market_Share $\left(\alpha_{4}\right)$ & & $\begin{array}{l}0.373 \\
(1.25)\end{array}$ & $\begin{array}{l}0.390 \\
(1.31)\end{array}$ & $\begin{array}{l}0.378 \\
(1.25)\end{array}$ & $\begin{array}{l}0.454 \\
(1.40)\end{array}$ & $\begin{array}{l}-0.277 \\
(-0.46)\end{array}$ & $\begin{array}{l}0.077 \\
(0.20)\end{array}$ & $\begin{array}{l}-0.140 \\
(-0.37)\end{array}$ & $\begin{array}{l}-0.142 \\
(-0.23)\end{array}$ & $\begin{array}{l}-0.108 \\
(-0.20)\end{array}$ & $\begin{array}{l}-0.104 \\
(-0.17)\end{array}$ \\
\hline Capital_Asset_Ratio $\left(\alpha_{5}\right)$ & & $\begin{array}{l}-0.023 \\
(-0.51)\end{array}$ & $\begin{array}{l}-0.023 \\
(-0.50)\end{array}$ & $\begin{array}{l}-0.023 \\
(-0.51)\end{array}$ & $\begin{array}{l}-0.017 \\
(-0.37)\end{array}$ & $\begin{array}{l}-0.014 \\
(-0.30)\end{array}$ & $\begin{array}{l}-0.006 \\
(-0.14)\end{array}$ & $\begin{array}{l}-0.010 \\
(-0.21)\end{array}$ & $\begin{array}{l}-0.017 \\
(-0.37)\end{array}$ & $\begin{array}{l}-0.076 \\
(-1.53)\end{array}$ & $\begin{array}{l}-0.010 \\
(-0.22)\end{array}$ \\
\hline $\begin{array}{l}\text { Islamic_Bank } \times \\
\text { Capital_Asset_Ratio }\left(\alpha_{I C}\right)\end{array}$ & & & & & & & & & & $\begin{array}{c}0.175 * * \\
(2.33)\end{array}$ & \\
\hline Loan_Growth $\left(\alpha_{6}\right)$ & & $\begin{array}{c}-0.030 \text { ***** } \\
(-5.28)\end{array}$ & $\begin{array}{c}-0.030 * * * \\
(-5.22)\end{array}$ & $\begin{array}{c}-0.030 \text { **** } \\
(-5.25)\end{array}$ & $\begin{array}{c}-0.029 * * * \\
(-5.05)\end{array}$ & $\begin{array}{c}-0.028 \text { **** } \\
(-4.86)\end{array}$ & $\begin{array}{c}-0.028 * * * \\
(-4.93)\end{array}$ & $\begin{array}{c}-0.028 * * * \\
(-4.96)\end{array}$ & $\begin{array}{c}-0.027 * * * \\
(-4.80)\end{array}$ & $\begin{array}{c}-0.027 * * * \\
(-4.83)\end{array}$ & $\begin{array}{c}-0.027 \text { **** } \\
(-4.79)\end{array}$ \\
\hline Noninterest_Income $\left(\alpha_{7}\right)$ & & $\begin{array}{l}-0.011 \\
(-0.79)\end{array}$ & $\begin{array}{l}-0.011 \\
(-0.80)\end{array}$ & $\begin{array}{l}-0.011 \\
(-0.78)\end{array}$ & $\begin{array}{l}-0.007 \\
(-0.55)\end{array}$ & $\begin{array}{l}-0.011 \\
(-0.81)\end{array}$ & $\begin{array}{l}-0.006 \\
(-0.46)\end{array}$ & $\begin{array}{l}-0.009 \\
(-0.67)\end{array}$ & $\begin{array}{l}-0.009 \\
(-0.69)\end{array}$ & $\begin{array}{l}-0.010 \\
(-0.76)\end{array}$ & $\begin{array}{l}-0.011 \\
(-0.80)\end{array}$ \\
\hline Cost_Inefficiency $\left(\alpha_{8}\right)$ & & $\begin{array}{l}0.005 \\
(0.57)\end{array}$ & $\begin{array}{l}0.005 \\
(0.58)\end{array}$ & $\begin{array}{l}0.005 \\
(0.55)\end{array}$ & $\begin{array}{l}0.003 \\
(0.34)\end{array}$ & $\begin{array}{l}0.004 \\
(0.47)\end{array}$ & $\begin{array}{l}0.003 \\
(0.31)\end{array}$ & $\begin{array}{l}0.004 \\
(0.40)\end{array}$ & $\begin{array}{l}0.006 \\
(0.65)\end{array}$ & $\begin{array}{l}0.005 \\
(0.53)\end{array}$ & $\begin{array}{l}0.005 \\
(0.56)\end{array}$ \\
\hline State_Bank $\left(\alpha_{9}\right)$ & & & $\begin{array}{l}-0.441 \\
(-0.48)\end{array}$ & $\begin{array}{l}-0.410 \\
(-0.45)\end{array}$ & $\begin{array}{l}-0.236 \\
(-0.25)\end{array}$ & $\begin{array}{l}-0.813 \\
(-0.86)\end{array}$ & $\begin{array}{l}-0.259 \\
(-0.27)\end{array}$ & $\begin{array}{l}-0.703 \\
(-0.78)\end{array}$ & $\begin{array}{l}-0.874 \\
(-0.92)\end{array}$ & $\begin{array}{l}-0.807 \\
(-0.85)\end{array}$ & $\begin{array}{l}-0.922 \\
(-0.98)\end{array}$ \\
\hline Foreign_Bank $\left(\alpha_{10}\right)$ & & & $\begin{array}{l}2.408 * * \\
(1.97)\end{array}$ & $\begin{array}{l}2.422 * * \\
(1.97)\end{array}$ & $\begin{array}{l}2.685^{* *} \\
(2.17)\end{array}$ & $\begin{array}{l}1.787 \\
(1.47)\end{array}$ & $\begin{array}{c}2.877 * * \\
(2.36)\end{array}$ & $\begin{array}{l}2.068^{*} \\
(1.73)\end{array}$ & $\begin{array}{l}1.736 \\
(1.43)\end{array}$ & $\begin{array}{l}1.649 \\
(1.36)\end{array}$ & $\begin{array}{l}1.799 \\
(1.48)\end{array}$ \\
\hline Subsidiary $\left(\alpha_{11}\right)$ & & & $\begin{array}{l}-0.971 \\
(-1.02)\end{array}$ & $\begin{array}{l}-0.976 \\
(-1.03)\end{array}$ & $\begin{array}{l}-0.794 \\
(-0.83)\end{array}$ & $\begin{array}{l}-0.276 \\
(-0.29)\end{array}$ & $\begin{array}{l}-0.646 \\
(-0.68)\end{array}$ & $\begin{array}{l}-0.549 \\
(-0.59)\end{array}$ & $\begin{array}{l}-0.207 \\
(-0.22)\end{array}$ & $\begin{array}{l}-0.342 \\
(-0.36)\end{array}$ & $\begin{array}{l}-0.333 \\
(-0.35)\end{array}$ \\
\hline Young_Bank $\left(\alpha_{12}\right)$ & & & & $\begin{array}{l}0.366 \\
(0.21)\end{array}$ & $\begin{array}{l}0.311 \\
(0.18)\end{array}$ & $\begin{array}{l}-0.092 \\
(-0.05)\end{array}$ & $\begin{array}{l}-0.038 \\
(-0.02)\end{array}$ & $\begin{array}{l}-0.205 \\
(-0.12)\end{array}$ & $\begin{array}{l}-0.152 \\
(-0.09)\end{array}$ & $\begin{array}{l}-0.397 \\
(-0.22)\end{array}$ & $\begin{array}{l}0.262 \\
(0.16)\end{array}$ \\
\hline Middle_Aged_Bank $\left(\alpha_{13}\right)$ & & & & $\begin{array}{l}0.187 \\
(0.23)\end{array}$ & $\begin{array}{l}0.202 \\
(0.25)\end{array}$ & $\begin{array}{l}0.180 \\
(0.22)\end{array}$ & $\begin{array}{l}-0.040 \\
(-0.05)\end{array}$ & $\begin{array}{l}-0.048 \\
(-0.06)\end{array}$ & $\begin{array}{l}0.101 \\
(0.12)\end{array}$ & $\begin{array}{l}0.149 \\
(0.18)\end{array}$ & $\begin{array}{l}0.146 \\
(0.18)\end{array}$ \\
\hline Muslim_Share $\left(\alpha_{14,1}\right)$ & & & & & $\begin{array}{l}-0.036 \\
(-1.39)\end{array}$ & & $\begin{array}{l}-0.005 \\
(-0.17)\end{array}$ & & & & \\
\hline Islamic_Bank $\times$ Muslim_Share $\left(\alpha_{\mathrm{IM}}\right)$ & & & & & & & $\begin{array}{l}-0.120^{* * *} \\
(-2.00)\end{array}$ & & & & \\
\hline Legal_System $\left(\alpha_{14,2}\right)$ & & & & & & & & $\begin{array}{c}3.627 * * * \\
(4.22)\end{array}$ & & & \\
\hline Islamic_Bank $\times$ Legal_System $\left(\alpha_{\mathrm{IL}}\right)$ & & & & & & & & $\begin{array}{c}-4.701 * * * \\
(-3.46)\end{array}$ & & & \\
\hline Domestic_Interest_Rate $\left(\alpha_{15}\right)$ & & & & & $\begin{array}{c}0.112 * \\
(1.96)\end{array}$ & $\begin{array}{l}0.210^{* * *} \\
(2.26)\end{array}$ & $\begin{array}{l}0.088 \\
(1.50)\end{array}$ & $\begin{array}{c}0.127 * * \\
(2.11)\end{array}$ & $\begin{array}{c}0.232 * * \\
(2.39)\end{array}$ & $\begin{array}{l}0.229^{* *} \\
(2.47)\end{array}$ & $\begin{array}{l}0.209 * * \\
(2.25)\end{array}$ \\
\hline $\begin{array}{l}\text { Islamic_Bank } \times \\
\text { Domestic_Interest_Rate }\left(\alpha_{\mathrm{ID}}\right)\end{array}$ & & & & & & & & & $\begin{array}{c}-0.399^{* *} \\
(-2.19)\end{array}$ & & \\
\hline HHI $\left(\alpha_{16}\right)$ & & & & & $\begin{array}{l}-2.515 \\
(-0.82)\end{array}$ & $\begin{array}{l}-3.727 \\
(-0.98)\end{array}$ & $\begin{array}{l}0.193 \\
(0.06)\end{array}$ & $\begin{array}{l}-2.771 \\
(-0.82)\end{array}$ & $\begin{array}{l}-4.037 \\
(-1.07)\end{array}$ & $\begin{array}{l}-4.749 \\
(-1.30)\end{array}$ & $\begin{array}{l}-3.878 \\
(-1.03)\end{array}$ \\
\hline GDP_Per_Capita $\left(\alpha_{17}\right)$ & & & & & $\begin{array}{l}0.013 \\
(0.45)\end{array}$ & $\begin{array}{l}0.069 \\
(0.63)\end{array}$ & $\begin{array}{l}0.017 \\
(0.59)\end{array}$ & $\begin{array}{l}-0.003 \\
(-0.11)\end{array}$ & $\begin{array}{l}0.073 \\
(0.68)\end{array}$ & $\begin{array}{l}0.031 \\
(0.28)\end{array}$ & $\begin{array}{l}0.065 \\
(0.60)\end{array}$ \\
\hline GDP_Per_Capita_Growth $\left(\alpha_{18}\right)$ & & & & & $\begin{array}{l}-0.006 \\
(-0.10)\end{array}$ & $\begin{array}{l}0.004 \\
(0.06)\end{array}$ & $\begin{array}{l}0.002 \\
(0.03)\end{array}$ & $\begin{array}{l}0.006 \\
(0.10)\end{array}$ & $\begin{array}{l}0.008 \\
(0.13)\end{array}$ & $\begin{array}{l}0.019 \\
(0.29)\end{array}$ & $\begin{array}{l}0.008 \\
(0.13)\end{array}$ \\
\hline Constant $\left(\alpha_{0}\right)$ & $\begin{array}{c}9.119 * * * \\
(21.45)\end{array}$ & $\begin{array}{c}22.543 * * * \\
(5.80)\end{array}$ & $\begin{array}{c}22.337 * * * \\
(5.70)\end{array}$ & $\begin{array}{c}22.193^{* * * *} \\
(5.56)\end{array}$ & $\begin{array}{c}23.896 * * * \\
(5.79)\end{array}$ & $\begin{array}{c}20.123 * * * * \\
(3.58)\end{array}$ & $\begin{array}{c}20.189 * * * \\
(4.43)\end{array}$ & $\begin{array}{l}18.516 * * * \\
(4.51)\end{array}$ & $\begin{array}{c}20.169 * * * \\
(3.64)\end{array}$ & $\begin{array}{c}22.796^{* * *} \\
(4.42)\end{array}$ & $\begin{array}{c}22.011 * * * \\
(3.77)\end{array}$ \\
\hline Year Dummies & No & No & No & No & No & Yes & Yes & Yes & Yes & Yes & Yes \\
\hline Country Dummies & No & No & No & No & No & Yes & No & No & Yes & Yes & Yes \\
\hline $\begin{array}{l}\text { Number of Obs } \\
\text { R-squared }\end{array}$ & $\begin{array}{l}3,259 \\
0.007\end{array}$ & $\begin{array}{l}1,897 \\
0.076\end{array}$ & $\begin{array}{l}1,897 \\
0.085\end{array}$ & $\begin{array}{l}1,897 \\
0.085\end{array}$ & $\begin{array}{l}1,897 \\
0.084\end{array}$ & $\begin{array}{l}1,897 \\
0.182\end{array}$ & $\begin{array}{l}1,897 \\
0.093 \\
\end{array}$ & $\begin{array}{l}1,897 \\
0.123\end{array}$ & $\begin{array}{l}1,897 \\
0.186\end{array}$ & $\begin{array}{l}1,897 \\
0.186\end{array}$ & $\begin{array}{l}1,897 \\
0.182 \\
\end{array}$ \\
\hline $\begin{array}{l}\mathrm{H}_{0}: \alpha_{14,1}=\alpha_{\mathrm{IM}}=0 \text { (F-stat.) } \\
\mathrm{H}_{0}: \alpha_{14,1}+\alpha_{\mathrm{IM}}=0 \text { (F-stat.) }\end{array}$ & & & & & & & $\begin{array}{l}5.17 * \\
5.17 * *\end{array}$ & & & & \\
\hline $\begin{array}{l}\mathrm{H}_{0}: \alpha_{14,2}=\alpha_{\mathrm{IL}}=0 \text { (F-stat.) } \\
\mathrm{H}_{0}: \alpha_{14,2}+\alpha_{\mathrm{IL}}=0 \text { (F-stat.) }\end{array}$ & & & & & & & & $\begin{array}{l}19.75^{* * * *} \\
0.87\end{array}$ & & & \\
\hline $\begin{array}{l}\mathrm{H}_{0}: \alpha_{15}=\alpha_{\mathrm{ID}}=0 \text { (F-stat.) } \\
\mathrm{H}_{0}: \alpha_{15}+\alpha_{\mathrm{ID}}=0 \text { (F-stat.) }\end{array}$ & & & & & & & & & $\begin{array}{c}9.07 * * \\
0.76\end{array}$ & & \\
\hline $\begin{array}{l}\mathrm{H}_{0}: \alpha_{5}=\alpha_{\mathrm{IC}}=0 \text { (F-stat.) } \\
\mathrm{H}_{0}: \alpha_{5}+\alpha_{\mathrm{IC}}=0 \text { (F-stat.) }\end{array}$ & & & & & & & & & & $\begin{array}{l}5.49^{*} \\
2.62\end{array}$ & \\
\hline $\begin{array}{l}\mathrm{H}_{0}: \alpha_{3}=\alpha_{\mathrm{IS}}=0 \text { (F-stat.) } \\
\mathrm{H}_{0}: \alpha_{3}+\alpha_{\mathrm{IS}}=0 \text { (F-stat.) }\end{array}$ & & & & & & & & & & & $\begin{array}{c}6.43 * * \\
0.01\end{array}$ \\
\hline
\end{tabular}

Dependent Variable: The ratio of loan loss reserves on gross loans is used as the credit risk proxy.

Explanatory Variables: Islamic Bank $=$ Islamic bank dummy, Islamic_Window_Bank $=$ Islamic window bank dummy, Size $=$ Logarithm of total assets, Islamic_Bank $\times$ Size $=$ Interaction term of Islamic_Bank and Size, Market_Share $=$ Logarithm of market share of total assets, orthogonalized on Size, Capital_Asset_Ratio $=$ The ratio of equity capital on total assets, Islamic_Bank $\times$ Capital_Asset_Ratio $=$ Interaction term of Islamic_Bank and Capital_Asset_Ratio, Loan_Growth = Annual growth rate of gross loans, Noninterest_Income $=$ Share of non-interest income in total operating income, Cost_Inefficiency $=$ Cost to income ratio, State_Bank $=$ State-owned bank dummy, Foreign_Bank $=$ Foreign-owned bank dummy, Subsidiary $=$ Subsidiary 
dummy, Young_Bank $=$ Young bank dummy, Middle_Aged_Bank = Middle-aged bank dummy, Muslim_Share $=$ Share of Muslims in population, Islamic_Bank $\times$ Muslim_Share $=$ Interaction term of Islamic_Bank and Muslim_Share, Legal_System $=$ Takes the value of zero, if the country does not use Shariá law to define its legal system, the value one for countries which consider Shariá together with other legal systems, and has the value two if the legal system is based exclusively on Shariá law, Islamic_Bank $\times$ Legal_System $=$ Interaction term of Islamic_Bank and Legal_System, Domestic_Interest_Rate $=$ Domestic interest rate, Islamic_Bank $\times$ Domestic_Interest_Rate $=$ Interaction term of Islamic_Bank and Domestic_Interest_Rate, HHI = Hirschman-Herfindahl index, in column (8) we use its orthogonalized value (orthogonalized on Legal_System due to high correlation). GDP_Per_Capita $=$ GDP per capita, GDP_Per_Capita_Growth $=$ Annual growth rate of GDP_Per_Capita.

In columns (1) to (6) credit risk of Islamic banks is compared to conventional banks, while in each stage a set of control variables is included into the model. In column (7), the interaction term of Islamic_Bank and Muslim Share (Islamic_Bank $\times$ Muslim Share) is included to analyze the possible impact of clients' religiosity on credit risk of Islamic banks. In column (8), we replace Muslim_Share and Islamic_Bank $\times$ Muslim_Share with Legal_System and Islamic_Bank $\times$ Legal_System respectively for further analysis of the possible impact of clients' religiosity on credit risk of Islamic banks. In column (9), we investigate whether credit risk of Islamic banks is more or less sensitive to domestic interest rate compared to conventional banks, by adding the interaction term of Islamic_Bank and Domestic_Interest_Rate (Islamic_Bank $\times$ Domestic_Interest_Rate). In column (10), we add the interaction of Islamic_Bank and Capital_Asset_Ratio (Islamic_Bank $\times$ Capital_Asset_Ratio) to understand whether leverage can discipline Islamic banks more effectively than conventional banks. In order to investigate whether size has different effect on credit risk of Islamic banks compared to conventional banks, in column (11) the interaction of Islamic_Bank and Size (Islamic_Bank $\times$ Size) is added to the model.

We apply random effect technique with robust standard errors for our estimations. All the accounting and macro level variables are lagged for one period. Robust $\mathrm{z}$-statistics are reported in parentheses. $* * *, * *$ and $*$ indicate significance at $1 \%, 5 \%$ and $10 \%$ respectively. 
Table IV. Insolvency Risk Model

This table presents the estimation of the insolvency risk model. In columns (1) to (8), we investigate whether insolvency risk of Islamic banks is, on average, higher or lower than conventional banks. In the last four columns we include various interaction variables highlighting whether religious factors influence insolvency risk

\begin{tabular}{|c|c|c|c|c|c|c|c|c|c|c|c|c|}
\hline Variables & $\begin{array}{c}\text { (1) } \\
\text { Zscore_rw }\end{array}$ & $\begin{array}{c}\text { (2) } \\
\text { Zscore_rw }\end{array}$ & $\begin{array}{c}\text { (3) } \\
\text { Zscore_rw }\end{array}$ & $\begin{array}{c}(4) \\
\text { Zscore_rw }\end{array}$ & $\begin{array}{c}\text { (5) } \\
\text { Zscore_rw }\end{array}$ & $\begin{array}{c}(6) \\
\text { Zscore_rw }\end{array}$ & $\begin{array}{c}\text { (7) } \\
\text { Zscore_P1_rw }\end{array}$ & $\begin{array}{c}(8) \\
\text { Zscore_P2_rw }\end{array}$ & $\begin{array}{c}\text { (9) } \\
\text { Zscore_rw }\end{array}$ & $\begin{array}{c}(10) \\
\text { Zscore_rw }\end{array}$ & $\begin{array}{c}(11) \\
\text { Zscore_rw }\end{array}$ & $\begin{array}{c}(12) \\
\text { Zscore_rw }\end{array}$ \\
\hline Islamic_Bank $\left(\beta_{1}\right)$ & $\begin{array}{l}-0.115 \\
(-0.89)\end{array}$ & $\begin{array}{l}-0.070 \\
(-0.58)\end{array}$ & $\begin{array}{l}-0.102 \\
(-0.82)\end{array}$ & $\begin{array}{l}-0.059 \\
(-0.47)\end{array}$ & $\begin{array}{l}-0.114 \\
(-0.92)\end{array}$ & $\begin{array}{l}0.088 \\
(0.57)\end{array}$ & $\begin{array}{l}0.054 \\
(0.46)\end{array}$ & $\begin{array}{l}0.118 \\
(0.74)\end{array}$ & $\begin{array}{l}-0.791 \\
(-1.07)\end{array}$ & $\begin{array}{l}0.153 \\
(0.65)\end{array}$ & $\begin{array}{l}0.514 \\
(0.62)\end{array}$ & $\begin{array}{l}0.263 \\
(0.88)\end{array}$ \\
\hline Islamic_Window_Bank $\left(\beta_{2}\right)$ & $\begin{array}{l}0.200 \\
(1.37)\end{array}$ & $\begin{array}{l}0.140 \\
(1.01)\end{array}$ & $\begin{array}{l}0.107 \\
(0.76)\end{array}$ & $\begin{array}{l}0.113 \\
(0.81)\end{array}$ & $\begin{array}{l}-0.039 \\
(-0.27)\end{array}$ & $\begin{array}{l}0.198 \\
(1.16)\end{array}$ & $\begin{array}{c}0.310^{\text {*** }} \\
(2.12)\end{array}$ & $\begin{array}{l}0.244 \\
(1.42)\end{array}$ & $\begin{array}{l}-0.043 \\
(-0.30)\end{array}$ & $\begin{array}{l}0.201 \\
(1.17)\end{array}$ & $\begin{array}{l}0.193 \\
(1.13)\end{array}$ & $\begin{array}{l}0.196 \\
(1.15)\end{array}$ \\
\hline Size $\left(\beta_{3}\right)$ & & $\begin{array}{l}-0.019 \\
(-0.74)\end{array}$ & $\begin{array}{l}-0.020 \\
(-0.76)\end{array}$ & $\begin{array}{l}-0.030 \\
(-1.09)\end{array}$ & $\begin{array}{l}-0.032 \\
(-1.23)\end{array}$ & $\begin{array}{l}-0.050 \\
(-1.63)\end{array}$ & $\begin{array}{c}0.064^{* *} \\
(2.41)\end{array}$ & $\begin{array}{c}-0.069 * * \\
(-2.21)\end{array}$ & $\begin{array}{l}-0.038 \\
(-1.41)\end{array}$ & $\begin{array}{c}-0.051^{*} \\
(-1.65)\end{array}$ & $\begin{array}{l}-0.044 \\
(-1.27)\end{array}$ & $\begin{array}{l}-0.049 \\
(-1.61)\end{array}$ \\
\hline Islamic_Bank $\times$ Size $\left(\beta_{\mathrm{IS}}\right)$ & & & & & & & & & & & $\begin{array}{l}-0.031 \\
(-0.53)\end{array}$ & \\
\hline Market_Share $\left(\beta_{4}\right)$ & & $\begin{array}{l}-0.028 \\
(-0.77)\end{array}$ & $\begin{array}{l}-0.032 \\
(-0.87)\end{array}$ & $\begin{array}{l}-0.024 \\
(-0.65)\end{array}$ & $\begin{array}{l}-0.017 \\
(-0.45)\end{array}$ & $\begin{array}{l}-0.045 \\
(-0.64)\end{array}$ & $\begin{array}{l}-0.045 \\
(-0.65)\end{array}$ & $\begin{array}{l}-0.050 \\
(-0.66)\end{array}$ & $\begin{array}{l}-0.005 \\
(-0.12)\end{array}$ & $\begin{array}{l}-0.042 \\
(-0.57)\end{array}$ & $\begin{array}{l}-0.051 \\
(-0.70)\end{array}$ & $\begin{array}{l}-0.049 \\
(-0.69)\end{array}$ \\
\hline Loan_Total_Earning_Asset_Ratio $\left(\beta_{5}\right)$ & & $\begin{array}{l}0.002 \\
(1.03)\end{array}$ & $\begin{array}{l}0.002 \\
(0.99)\end{array}$ & $\begin{array}{l}0.002 \\
(0.91)\end{array}$ & $\begin{array}{l}0.001 \\
(0.68)\end{array}$ & $\begin{array}{l}0.001 \\
(0.49)\end{array}$ & $\begin{array}{l}0.002 \\
(0.87)\end{array}$ & $\begin{array}{l}0.001 \\
(0.36)\end{array}$ & $\begin{array}{l}0.001 \\
(0.60)\end{array}$ & $\begin{array}{l}0.001 \\
(0.50)\end{array}$ & $\begin{array}{l}0.001 \\
(0.48)\end{array}$ & $\begin{array}{l}0.002 \\
(0.72)\end{array}$ \\
\hline $\begin{array}{l}\text { Islamic_Bank } \times \\
\text { Loan_Total_Earning_Asset_Ratio }\left(\beta_{\mathrm{IL}}\right)\end{array}$ & & & & & & & & & & & & $\begin{array}{l}-0.003 \\
(-0.68)\end{array}$ \\
\hline Asset_Growth $\left(\beta_{6}\right)$ & & $\begin{array}{l}-0.000 \\
(-0.17)\end{array}$ & $\begin{array}{l}-0.000 \\
(-0.22)\end{array}$ & $\begin{array}{l}0.000 \\
(0.02)\end{array}$ & $\begin{array}{l}0.000 \\
(0.32)\end{array}$ & $\begin{array}{l}0.001 \\
(0.67)\end{array}$ & $\begin{array}{l}0.000 \\
(0.12)\end{array}$ & $\begin{array}{l}0.001 \\
(0.77)\end{array}$ & $\begin{array}{l}0.000 \\
(0.27)\end{array}$ & $\begin{array}{l}0.001 \\
(0.68)\end{array}$ & $\begin{array}{l}0.001 \\
(0.66)\end{array}$ & $\begin{array}{l}0.001 \\
(0.72)\end{array}$ \\
\hline Noninterest_Income $\left(\beta_{7}\right)$ & & $\begin{array}{c}-0.005 * * \\
(-2.49)\end{array}$ & $\begin{array}{c}-0.005^{* *} \\
(-2.43)\end{array}$ & $\begin{array}{c}-0.005 * * \\
(-2.45)\end{array}$ & $\begin{array}{c}-0.006 * * * \\
(-2.91)\end{array}$ & $\begin{array}{c}-0.005^{* *} \\
(-2.23)\end{array}$ & $\begin{array}{c}-0.006^{* * *} \\
(-2.74)\end{array}$ & $\begin{array}{c}-0.005^{* *} \\
(-2.35)\end{array}$ & $\begin{array}{c}-0.006 * * * \\
(-2.87)\end{array}$ & $\begin{array}{c}-0.005^{* *} \\
(-2.20)\end{array}$ & $\begin{array}{c}-0.005 * * \\
(-2.23)\end{array}$ & $\begin{array}{c}-0.005 * * \\
(-2.22)\end{array}$ \\
\hline Cost_Inefficiency $\left(\beta_{8}\right)$ & & $\begin{array}{c}-0.010^{* * * *} \\
(-6.81)\end{array}$ & $\begin{array}{l}-0.010^{* * * *} \\
(-6.78)\end{array}$ & $\begin{array}{c}-0.010 * * * \\
(-6.72)\end{array}$ & $\begin{array}{c}-0.009 * * * \\
(-5.78)\end{array}$ & $\begin{array}{c}-0.009^{* * * *} \\
(-5.69)\end{array}$ & $\begin{array}{c}-0.018 * * * * \\
(-8.00)\end{array}$ & $\begin{array}{c}-0.008 * * * \\
(-5.30)\end{array}$ & $\begin{array}{c}-0.009 * * * \\
(-5.83)\end{array}$ & $\begin{array}{c}-0.009 * * * \\
(-5.69)\end{array}$ & $\begin{array}{c}-0.009 * * * \\
(-5.63)\end{array}$ & $\begin{array}{c}-0.009 * * * \\
(-5.68)\end{array}$ \\
\hline State_Bank $\left(\beta_{9}\right)$ & & & $\begin{array}{l}-0.041 \\
(-0.30)\end{array}$ & $\begin{array}{l}-0.063 \\
(-0.45)\end{array}$ & $\begin{array}{l}-0.006 \\
(-0.04)\end{array}$ & $\begin{array}{l}0.156 \\
(1.26)\end{array}$ & $\begin{array}{l}0.062 \\
(0.51)\end{array}$ & $\begin{array}{l}0.175 \\
(1.31)\end{array}$ & $\begin{array}{l}-0.005 \\
(-0.03)\end{array}$ & $\begin{array}{l}0.154 \\
(1.25)\end{array}$ & $\begin{array}{l}0.162 \\
(1.30)\end{array}$ & $\begin{array}{l}0.157 \\
(1.27)\end{array}$ \\
\hline Foreign_Bank $\left(\beta_{10}\right)$ & & & $\begin{array}{l}-0.058 \\
(-0.37)\end{array}$ & $\begin{array}{l}-0.076 \\
(-0.50)\end{array}$ & $\begin{array}{l}-0.087 \\
(-0.57)\end{array}$ & $\begin{array}{l}-0.158 \\
(-1.03)\end{array}$ & $\begin{array}{l}-0.114 \\
(-0.78)\end{array}$ & $\begin{array}{l}-0.128 \\
(-0.81)\end{array}$ & $\begin{array}{l}-0.111 \\
(-0.72)\end{array}$ & $\begin{array}{l}-0.157 \\
(-1.03)\end{array}$ & $\begin{array}{l}-0.157 \\
(-1.03)\end{array}$ & $\begin{array}{l}-0.149 \\
(-0.97)\end{array}$ \\
\hline Subsidiary $\left(\beta_{11}\right)$ & & & $\begin{array}{c}-0.299 * * * \\
(-2.69)\end{array}$ & $\begin{array}{c}-0.298 * * * \\
(-2.66)\end{array}$ & $\begin{array}{c}-0.357 * * * \\
(-3.27)\end{array}$ & $\begin{array}{c}-0.318^{* * * *} \\
(-2.63)\end{array}$ & $\begin{array}{l}-0.205 \\
(-1.50)\end{array}$ & $\begin{array}{c}-0.329 * * \\
(-2.50)\end{array}$ & $\begin{array}{c}-0.366^{* * *} \\
(-3.35)\end{array}$ & $\begin{array}{c}-0.316^{* * * *} \\
(-2.60)\end{array}$ & $\begin{array}{c}-0.315 * * * \\
(-2.60)\end{array}$ & $\begin{array}{c}-0.317 * * * \\
(-2.62)\end{array}$ \\
\hline Young_Bank $\left(\beta_{12}\right)$ & & & & $\begin{array}{c}-0.393 * * \\
(-2.03)\end{array}$ & $\begin{array}{c}-0.389 * * \\
(-1.97)\end{array}$ & $\begin{array}{c}-0.348^{*} \\
(-1.65)\end{array}$ & $\begin{array}{c}-0.771 * * * \\
(-3.04)\end{array}$ & $\begin{array}{l}-0.246 \\
(-1.21)\end{array}$ & $\begin{array}{c}-0.404 * * \\
(-1.98)\end{array}$ & $\begin{array}{c}-0.347^{*} \\
(-1.65)\end{array}$ & $\begin{array}{c}-0.358^{*} \\
(-1.68)\end{array}$ & $\begin{array}{c}-0.353^{*} \\
(-1.69)\end{array}$ \\
\hline Middle_Aged_Bank $\left(\beta_{13}\right)$ & & & & $\begin{array}{l}-0.209 \\
(-1.58)\end{array}$ & $\begin{array}{l}-0.203 \\
(-1.60)\end{array}$ & $\begin{array}{l}-0.160 \\
(-1.23)\end{array}$ & $\begin{array}{l}0.009 \\
(0.07)\end{array}$ & $\begin{array}{l}-0.177 \\
(-1.41)\end{array}$ & $\begin{array}{l}-0.203 \\
(-1.60)\end{array}$ & $\begin{array}{l}-0.162 \\
(-1.24)\end{array}$ & $\begin{array}{l}-0.157 \\
(-1.21)\end{array}$ & $\begin{array}{l}-0.161 \\
(-1.24)\end{array}$ \\
\hline Muslim_Share $\left(\beta_{14}\right)$ & & & & & $\begin{array}{c}-0.011 * * * \\
(-3.11)\end{array}$ & & & & $\begin{array}{c}-0.013 * * * \\
(-3.34)\end{array}$ & & & \\
\hline Islamic_Bank $\times$ Muslim_Share $\left(\beta_{\mathrm{IM}}\right)$ & & & & & & & & & $\begin{array}{l}0.008 \\
(0.91)\end{array}$ & & & \\
\hline Domestic_Interest_Rate $\left(\beta_{15}\right)$ & & & & & $\begin{array}{c}-0.042 * * * \\
(-7.55)\end{array}$ & $\begin{array}{c}-0.048 * * * \\
(-4.97)\end{array}$ & $\begin{array}{c}-0.037 * * * \\
(-3.79)\end{array}$ & $\begin{array}{c}-0.048 * * * \\
(-5.86)\end{array}$ & $\begin{array}{c}-0.043 * * * \\
(-7.22)\end{array}$ & $\begin{array}{c}-0.047 * * * \\
(-4.94)\end{array}$ & $\begin{array}{c}-0.048 * * * \\
(-4.97)\end{array}$ & $\begin{array}{c}-0.047 * * * \\
(-4.98)\end{array}$ \\
\hline $\begin{array}{l}\text { Islamic_Bank } \times \text { Domestic_Interest_Rate } \\
\left(\beta_{\text {ID }}\right)\end{array}$ & & & & & & & & & & $\begin{array}{l}-0.012 \\
(-0.35)\end{array}$ & & \\
\hline HHI $\left(\beta_{16}\right)$ & & & & & $\begin{array}{l}-0.563 \\
(-1.45)\end{array}$ & $\begin{array}{c}-0.949 * \\
(-1.75)\end{array}$ & $\begin{array}{l}-0.796 \\
(-1.44)\end{array}$ & $\begin{array}{c}-1.144 * * \\
(-2.02)\end{array}$ & $\begin{array}{l}-0.502 \\
(-1.23)\end{array}$ & $\begin{array}{c}-0.956^{*} \\
(-1.75)\end{array}$ & $\begin{array}{r}-0.936^{*} \\
(-1.73)\end{array}$ & $\begin{array}{l}-0.935^{*} \\
(-1.72)\end{array}$ \\
\hline GDP_Per_Capita $\left(\beta_{17}\right)$ & & & & & $\begin{array}{c}-0.005^{*} \\
(-1.66)\end{array}$ & $\begin{array}{c}-0.066^{* * * *} \\
(-2.81)\end{array}$ & $\begin{array}{c}-0.049 * * * \\
(-2.78)\end{array}$ & $\begin{array}{c}-0.075 * * * \\
(-3.08)\end{array}$ & $\begin{array}{c}-0.006^{*} \\
(-1.86)\end{array}$ & $\begin{array}{c}-0.065^{* * *} \\
(-2.80)\end{array}$ & $\begin{array}{c}-0.066 * * * \\
(-2.80)\end{array}$ & $\begin{array}{c}-0.065 * * * \\
(-2.79)\end{array}$ \\
\hline GDP_Per_Capita_Growth $\left(\beta_{18}\right)$ & & & & & $\begin{array}{c}-0.015^{*} \\
(-1.71)\end{array}$ & $\begin{array}{l}-0.006 \\
(-0.59)\end{array}$ & $\begin{array}{l}0.002 \\
(0.13)\end{array}$ & $\begin{array}{l}-0.009 \\
(-0.86)\end{array}$ & $\begin{array}{l}-0.014 \\
(-1.57)\end{array}$ & $\begin{array}{l}-0.006 \\
(-0.58)\end{array}$ & $\begin{array}{l}-0.006 \\
(-0.59)\end{array}$ & $\begin{array}{l}-0.006 \\
(-0.63)\end{array}$ \\
\hline Constant $\left(\beta_{0}\right)$ & $\begin{array}{c}3.399 * * * \\
(61.32)\end{array}$ & $\begin{array}{c}4.315^{* * *} \\
(10.89)\end{array}$ & $\begin{array}{c}4.400^{* * * *} \\
(11.00)\end{array}$ & $\begin{array}{c}4.560^{* * * *} \\
(10.99)\end{array}$ & $\begin{array}{c}6.112 * * * \\
(13.55)\end{array}$ & $\begin{array}{l}5.943 * * * \\
(9.96)\end{array}$ & $\begin{array}{l}2.080^{* * * *} \\
(3.86)\end{array}$ & $\begin{array}{l}6.191 * * * \\
(10.14)\end{array}$ & $\begin{array}{c}6.343 * * * \\
(13.40)\end{array}$ & $\begin{array}{l}5.943 * * * \\
(9.96)\end{array}$ & $\begin{array}{l}5.866 * * * * \\
(9.09)\end{array}$ & $\begin{array}{l}5.882 * * * \\
(9.72)\end{array}$ \\
\hline Year Dummies & No & No & No & No & No & Yes & Yes & Yes & Yes & Yes & Yes & Yes \\
\hline Country Dummies & No & No & No & No & No & Yes & Yes & Yes & No & Yes & Yes & Yes \\
\hline $\begin{array}{l}\text { Number of Obs } \\
\text { R-squared }\end{array}$ & $\begin{array}{l}2,129 \\
0.001\end{array}$ & $\begin{array}{l}1,910 \\
0.040\end{array}$ & $\begin{array}{l}1,910 \\
0.043\end{array}$ & $\begin{array}{l}1,910 \\
0.047\end{array}$ & $\begin{array}{l}1,910 \\
0.097\end{array}$ & $\begin{array}{l}1,910 \\
0.161\end{array}$ & $\begin{array}{l}1,813 \\
0.226\end{array}$ & $\begin{array}{l}1,931 \\
0.176\end{array}$ & $\begin{array}{l}1,910 \\
0.103\end{array}$ & $\begin{array}{l}1,910 \\
0.161\end{array}$ & $\begin{array}{l}1,910 \\
0.161\end{array}$ & $\begin{array}{l}1,910 \\
0.161\end{array}$ \\
\hline $\begin{array}{l}\mathrm{H}_{0}: \beta_{14}=\beta_{\mathrm{IM}}=0 \text { (F-stat.) } \\
\mathrm{H}_{0}: \beta_{14}+\beta_{\mathrm{IM}}=0 \text { (F-stat.) }\end{array}$ & & & & & & & & & $\begin{array}{c}11.4 * * * \\
0.41\end{array}$ & & & \\
\hline $\begin{array}{l}\mathrm{H}_{0}: \beta_{15}=\beta_{\mathrm{ID}}=0 \text { (F-stat.) } \\
\mathrm{H}_{0}: \beta_{15}+\beta_{\mathrm{ID}}=0 \text { (F-stat.) }\end{array}$ & & & & & & & & & & $\begin{array}{c}24.78 * * * \\
2.87 *\end{array}$ & & \\
\hline $\begin{array}{l}\mathrm{H}_{0}: \beta_{3}=\beta_{\text {IS }}=0 \text { (F-stat.) } \\
\mathrm{H}_{0}: \beta_{3}+\beta_{\text {IS }}=0 \text { (F-stat.) }\end{array}$ & & & & & & & & & & & $\begin{array}{c}3.6 \\
2.23\end{array}$ & \\
\hline $\begin{array}{l}\mathrm{H}_{0}: \beta_{5}=\beta_{\mathrm{IS}}=0 \text { (F-stat.) } \\
\mathrm{H}_{0}: \beta_{5}+\beta_{\mathrm{IS}}=0 \text { (F-stat.) }\end{array}$ & & & & & & & & & & & & $\begin{array}{l}0.67 \\
0.14\end{array}$ \\
\hline
\end{tabular}

Dependent Variables: Zscore_rw = Logarithm of rolling-window Zscore which is equal to (ROAA+Capital_Asset_Ratio)/SDROAA_rw, ROAA = Return on average assets, Capital_Asset_Ratio $=$ Equity capital to asset ratio, SDROAA_rw $=$ Standard deviation of ROAA over 3 years (current year and two previous consecutive years). Banks need to have three consecutive observations. Acquiring banks are excluded from the sample, since the volatility on their assets returns can be due to the acquisition. Zscore_P1_rw $=$ Logarithm of ROAA/SDROAA3_rw, Zscore_P2_rw = Logarithm of Capital_Asset_Ratio/SDROAA3_rw.

Variable definitions: Islamic_Bank = Islamic bank dummy, Islamic_Window_Bank = Islamic window bank dummy, Size $=$ Logarithm of total assets, Islamic_Bank $\times$ Size $=$ Interaction term of Islamic_Bank and Size, Market_Share $=$ Logarithm of market share of total assets, orthogonalized on Size, Loan_Total_Earning_Asset_Ratio $=$ Share of net loans in total earning assets, Islamic_Bank $\times$ Loan_Total_Earning_Asset_Ratio $=$ Interaction term of Islamic_Bank and Loan_Total_Earning_Asset_Ratio, Asset_Growth $=$ Annual growth rate of total assets, Noninterest_Income $=$ Share of non-interest income in total operating income, Cost_Inefficiency $=$ Cost to income ratio, State_Bank $=$ State-owned bank dummy, Foreign_Bank $=$ Foreign-owned bank dummy, Subsidiary = Subsidiary dummy, Young_Bank = Young bank dummy, Middle_Aged_Bank = Middle-aged bank dummy, Muslim Share $=$ Share of Muslims in population, Islamic_Bank $\times$ Muslim_Share $=$ Interaction term of Islamic_Bank and Muslim_Share, Domestic_Interest_Rate $=$ Domestic interest rate, Islamic_Bank $\times$ Domestic_Interest_Rate $=$ Interaction term of Islamic_Bank and Domestic_Interest_Rate, HHI = Hirschman-Herfindahl index, GDP_Per_Capita $=$ GDP per capita, 
GDP_Per_Capita_Growth $=$ Annual growth rate of GDP_Per_Capita.

In columns (1) to (6) insolvency risk of Islamic banks is compared to conventional banks, while in each stage a set of control variables is included into the model. In columns (7) and (8), insolvency risk proxy is replaced by Zscore_Pl_rw and Zscore_P2 rw, respectively. In column (9), the interaction term of Islamic Bank and Muslim_Share (Islamic Bank $\times$ Muslim_Share) is added to analyze the possible impact of clients' religiosity on insolvency risk of Islamic banks. In column (10), we investigate whether insolvency risk of Islamic banks is more or less sensitive to domestic interest rate compared to conventional banks, by adding the interaction term of Islamic_Bank and Domestic_Interest_Rate (Islamic_Bank $\times$ Domestic_Interest_Rate). In order to understand whether size has different effect on insolvency risk of Islamic banks compared to conventional banks, in column (11) the interaction of Islamic_Bank and Size (Islamic_Bank $\times$ Size) is added to the model. We add the interaction term of Islamic_Bank and Loan_Total_Earning_Asset_Ratio (Islamic_Bank $\times$ Loan_Total_Earning_Asset_Ratio) in column (12) to investigate whether the composition of total earning assets can have a significantly different effect on Islamic banks' stability compared to conventional banks.

We apply random effect technique with robust standard errors for our estimations. All the accounting and macro level variables are lagged for one period. Robust z-statistics are reported in parentheses. $* * *, * *$ and $*$ indicate significance at $1 \%, 5 \%$ and $10 \%$ respectively. 
Table V. Bank Interest Rate Model

This table presents the results of the bank interest rate model. In the first five columns, we investigate whether interest rate proxies of Islamic banks are, on average, higher or lower than conventional banks. In columns (6) to (10), the sensitivity of interest income and expense of Islamic banks to domestic interest rate are analysed.

\begin{tabular}{|c|c|c|c|c|c|c|c|c|c|c|}
\hline Variables & $\begin{array}{c}\text { (1) } \\
\text { Net_Interest_Margin } \\
\text { (A) }\end{array}$ & $\begin{array}{c}\text { (2) } \\
\text { Interest_Income_Rate } \\
\text { (B) }\end{array}$ & $\begin{array}{c}\text { (3) } \\
\text { Interest_Expense_Rate } \\
\text { (C) }\end{array}$ & $\begin{array}{c}\text { (4) } \\
\text { Loan_Rate } \\
\text { (D) }\end{array}$ & $\begin{array}{c}\text { (5) } \\
\text { Deposit_Rate } \\
\text { (E) }\end{array}$ & $\begin{array}{l}(6) \\
\mathrm{A}\end{array}$ & $\begin{array}{l}\text { (7) } \\
\text { B }\end{array}$ & $\begin{array}{l}(8) \\
\text { C }\end{array}$ & $\begin{array}{l}\text { (9) } \\
\mathrm{D}\end{array}$ & $\begin{array}{c}(10) \\
\mathrm{E}\end{array}$ \\
\hline Islamic_Bank $\left(\gamma_{1}\right)$ & $\begin{array}{l}0.249 \\
(0.97)\end{array}$ & $\begin{array}{l}-0.487 \\
(-1.44)\end{array}$ & $\begin{array}{l}-0.125 \\
(-0.47)\end{array}$ & $\begin{array}{l}-0.479 \\
(-0.87)\end{array}$ & $\begin{array}{l}-0.228 \\
(-0.60)\end{array}$ & $\begin{array}{l}0.346 \\
(1.03)\end{array}$ & $\begin{array}{c}0.752 * \\
(1.77)\end{array}$ & $\begin{array}{c}0.723 * \\
(1.88)\end{array}$ & $\begin{array}{l}0.317 \\
(0.44)\end{array}$ & $\begin{array}{l}0.129 \\
(0.31)\end{array}$ \\
\hline Islamic_Window_Bank $\left(\gamma_{2}\right)$ & $\begin{array}{l}0.189 \\
(0.86)\end{array}$ & $\begin{array}{l}0.036 \\
(0.12)\end{array}$ & $\begin{array}{l}-0.132 \\
(-0.72)\end{array}$ & $\begin{array}{l}0.235 \\
(0.41)\end{array}$ & $\begin{array}{l}-0.007 \\
(-0.02)\end{array}$ & $\begin{array}{l}0.198 \\
(0.89)\end{array}$ & $\begin{array}{l}0.128 \\
(0.42)\end{array}$ & $\begin{array}{l}-0.072 \\
(-0.40)\end{array}$ & $\begin{array}{l}0.312 \\
(0.54)\end{array}$ & $\begin{array}{l}0.025 \\
(0.07)\end{array}$ \\
\hline Size $\left(\gamma_{3}\right)$ & $\begin{array}{l}-0.051 \\
(-1.08)\end{array}$ & $\begin{array}{l}-0.097 \\
(-1.40)\end{array}$ & $\begin{array}{l}0.064 \\
(0.98)\end{array}$ & $\begin{array}{l}-0.047 \\
(-0.38)\end{array}$ & $\begin{array}{l}-0.056 \\
(-0.65)\end{array}$ & $\begin{array}{l}-0.052 \\
(-1.11)\end{array}$ & $\begin{array}{l}-0.115^{*} \\
(-1.66)\end{array}$ & $\begin{array}{l}0.052 \\
(0.83)\end{array}$ & $\begin{array}{l}-0.062 \\
(-0.52)\end{array}$ & $\begin{array}{l}-0.063 \\
(-0.76)\end{array}$ \\
\hline Market_Share $\left(\gamma_{4}\right)$ & $\begin{array}{l}0.051 \\
(0.41)\end{array}$ & $\begin{array}{l}0.201 \\
(1.24)\end{array}$ & $\begin{array}{l}-0.317 \\
(-1.42)\end{array}$ & $\begin{array}{l}-0.769 \\
(-1.47)\end{array}$ & $\begin{array}{l}-0.193 \\
(-0.64)\end{array}$ & $\begin{array}{l}0.055 \\
(0.45)\end{array}$ & $\begin{array}{l}0.251 \\
(1.55)\end{array}$ & $\begin{array}{l}-0.285 \\
(-1.34)\end{array}$ & $\begin{array}{l}-0.713 \\
(-1.44)\end{array}$ & $\begin{array}{l}-0.165 \\
(-0.56)\end{array}$ \\
\hline Capital_Asset_Ratio $\left(\gamma_{5}\right)$ & $\begin{array}{c}0.016^{* * *} \\
(3.15)\end{array}$ & $\begin{array}{l}-0.001 \\
(-0.13)\end{array}$ & $\begin{array}{l}-0.005 \\
(-0.98)\end{array}$ & $\begin{array}{l}-0.015 \\
(-1.38)\end{array}$ & $\begin{array}{l}-0.012 \\
(-1.47)\end{array}$ & $\begin{array}{c}0.016 * * * \\
(3.14)\end{array}$ & $\begin{array}{l}-0.002 \\
(-0.26)\end{array}$ & $\begin{array}{l}-0.006 \\
(-1.09)\end{array}$ & $\begin{array}{l}-0.016 \\
(-1.51)\end{array}$ & $\begin{array}{l}-0.013 \\
(-1.57)\end{array}$ \\
\hline Noninterest_Income $\left(\gamma_{6}\right)$ & $\begin{array}{c}-0.033 * * * \\
(-6.80)\end{array}$ & $\begin{array}{c}-0.021 * * * \\
(-3.54)\end{array}$ & $\begin{array}{c}0.007 * \\
(1.65)\end{array}$ & $\begin{array}{l}0.005 \\
(0.66)\end{array}$ & $\begin{array}{l}0.001 \\
(0.19)\end{array}$ & $\begin{array}{c}-0.033 * * * * \\
(-6.80)\end{array}$ & $\begin{array}{c}-0.021 * * * \\
(-3.46)\end{array}$ & $\begin{array}{l}0.007 * \\
(1.76)\end{array}$ & $\begin{array}{l}0.006 \\
(0.78)\end{array}$ & $\begin{array}{l}0.002 \\
(0.24)\end{array}$ \\
\hline Cost_Inefficiency $\left(\gamma_{7}\right)$ & $\begin{array}{c}-0.013 * * * \\
(-4.63)\end{array}$ & $\begin{array}{c}-0.008 * * * \\
(-2.79)\end{array}$ & $\begin{array}{l}-0.000 \\
(-0.09)\end{array}$ & $\begin{array}{l}0.002 \\
(0.30)\end{array}$ & $\begin{array}{l}0.004 \\
(0.76)\end{array}$ & $\begin{array}{c}-0.013 * * * \\
(-4.65)\end{array}$ & $\begin{array}{c}-0.008 * * * \\
(-2.63)\end{array}$ & $\begin{array}{l}0.000 \\
(0.11)\end{array}$ & $\begin{array}{l}0.002 \\
(0.26)\end{array}$ & $\begin{array}{l}0.004 \\
(0.76)\end{array}$ \\
\hline Loan_Loss_Reserve $\left(\gamma_{8}\right)$ & $\begin{array}{l}-0.003 \\
(-0.45)\end{array}$ & $\begin{array}{l}-0.010 \\
(-1.08)\end{array}$ & $\begin{array}{l}-0.003 \\
(-0.49)\end{array}$ & $\begin{array}{l}-0.010 \\
(-0.76)\end{array}$ & $\begin{array}{l}0.009 \\
(0.89)\end{array}$ & $\begin{array}{l}-0.003 \\
(-0.46)\end{array}$ & $\begin{array}{l}-0.011 \\
(-1.19)\end{array}$ & $\begin{array}{l}-0.003 \\
(-0.57)\end{array}$ & $\begin{array}{l}-0.011 \\
(-0.83)\end{array}$ & $\begin{array}{l}0.008 \\
(0.86)\end{array}$ \\
\hline State_Bank $\left(\gamma_{9}\right)$ & $\begin{array}{l}-0.227 \\
(-0.98)\end{array}$ & $\begin{array}{l}-0.085 \\
(-0.23)\end{array}$ & $\begin{array}{l}0.187 \\
(0.51)\end{array}$ & $\begin{array}{l}0.087 \\
(0.15)\end{array}$ & $\begin{array}{l}-0.274 \\
(-0.56)\end{array}$ & $\begin{array}{l}-0.229 \\
(-0.98)\end{array}$ & $\begin{array}{l}-0.116 \\
(-0.31)\end{array}$ & $\begin{array}{l}0.172 \\
(0.47)\end{array}$ & $\begin{array}{l}0.059 \\
(0.10)\end{array}$ & $\begin{array}{l}-0.286 \\
(-0.58)\end{array}$ \\
\hline Foreign_Bank $\left(\gamma_{10}\right)$ & $\begin{array}{c}-0.484 * \\
(-1.89)\end{array}$ & $\begin{array}{c}-1.237 * * * \\
(-3.26)\end{array}$ & $\begin{array}{l}-0.308 \\
(-0.97)\end{array}$ & $\begin{array}{l}-0.647 \\
(-0.52)\end{array}$ & $\begin{array}{l}0.312 \\
(0.70)\end{array}$ & $\begin{array}{c}-0.483^{*} \\
(-1.89)\end{array}$ & $\begin{array}{c}-1.245 * * * \\
(-3.35)\end{array}$ & $\begin{array}{l}-0.323 \\
(-1.00)\end{array}$ & $\begin{array}{l}-0.598 \\
(-0.49)\end{array}$ & $\begin{array}{l}0.312 \\
(0.69)\end{array}$ \\
\hline Subsidiary $\left(\gamma_{11}\right)$ & $\begin{array}{l}0.264 \\
(1.24)\end{array}$ & $\begin{array}{c}-0.737 * * \\
(-2.39)\end{array}$ & $\begin{array}{c}-0.745 * * * \\
(-3.65)\end{array}$ & $\begin{array}{l}-0.751 \\
(-1.37)\end{array}$ & $\begin{array}{c}-0.740^{* * *} \\
(-2.33)\end{array}$ & $\begin{array}{l}0.269 \\
(1.26)\end{array}$ & $\begin{array}{c}-0.712 \text { ** } \\
(-2.31)\end{array}$ & $\begin{array}{c}-0.726 * * * \\
(-3.57)\end{array}$ & $\begin{array}{l}-0.700 \\
(-1.28)\end{array}$ & $\begin{array}{c}-0.715 * * \\
(-2.26)\end{array}$ \\
\hline Young_Bank $\left(\gamma_{12}\right)$ & $\begin{array}{l}0.537 \\
(1.50)\end{array}$ & $\begin{array}{l}-0.348 \\
(-0.79)\end{array}$ & $\begin{array}{l}-0.466 \\
(-1.52)\end{array}$ & $\begin{array}{l}1.530 \\
(0.86)\end{array}$ & $\begin{array}{l}1.412 * \\
(1.76)\end{array}$ & $\begin{array}{l}0.539 \\
(1.50)\end{array}$ & $\begin{array}{l}-0.332 \\
(-0.74)\end{array}$ & $\begin{array}{l}-0.459 \\
(-1.47)\end{array}$ & $\begin{array}{l}1.490 \\
(0.84)\end{array}$ & $\begin{array}{l}1.391^{*} \\
(1.74)\end{array}$ \\
\hline Middle_Aged_Bank $\left(\gamma_{13}\right)$ & $\begin{array}{c}0.408 * * \\
(1.96)\end{array}$ & $\begin{array}{l}0.280 \\
(0.97)\end{array}$ & $\begin{array}{l}-0.130 \\
(-0.60)\end{array}$ & $\begin{array}{l}0.780 * \\
(1.72)\end{array}$ & $\begin{array}{l}0.607 * \\
(1.95)\end{array}$ & $\begin{array}{c}0.407 * \\
(1.95)\end{array}$ & $\begin{array}{l}0.261 \\
(0.89)\end{array}$ & $\begin{array}{l}-0.154 \\
(-0.71)\end{array}$ & $\begin{array}{l}0.739 \\
(1.62)\end{array}$ & $\begin{array}{c}0.595^{*} \\
(1.91)\end{array}$ \\
\hline Domestic_Interest_Rate $\left(\gamma_{15}\right)$ & $\begin{array}{c}0.055^{* * * *} \\
(2.77)\end{array}$ & $\begin{array}{c}0.176^{* * * *} \\
(8.12)\end{array}$ & $\begin{array}{c}0.101 * * * \\
(8.97)\end{array}$ & $\begin{array}{l}0.071 \\
(1.09)\end{array}$ & $\begin{array}{c}0.180^{* * * *} \\
(4.13)\end{array}$ & $\begin{array}{c}0.054 * * * \\
(2.77)\end{array}$ & $\begin{array}{c}0.176^{* * * *} \\
(8.12)\end{array}$ & $\begin{array}{c}0.101 * * * \\
(8.93)\end{array}$ & $\begin{array}{l}0.076 \\
(1.16)\end{array}$ & $\begin{array}{c}0.181^{* * * *} \\
(4.14)\end{array}$ \\
\hline $\begin{array}{l}\text { Islamic_Bank } \times \\
\text { Domestic_Interest_Rate }\left(\gamma_{\mathrm{ID}}\right)\end{array}$ & & & & & & $\begin{array}{l}-0.016 \\
(-0.32)\end{array}$ & $\begin{array}{c}-0.198 * * * \\
(-3.03)\end{array}$ & $\begin{array}{c}-0.138 * * * \\
(-2.65)\end{array}$ & $\begin{array}{l}-0.139 \\
(-1.50)\end{array}$ & $\begin{array}{l}-0.058 \\
(-1.10)\end{array}$ \\
\hline $\mathrm{HHI}\left(\gamma_{16}\right)$ & $\begin{array}{l}-0.327 \\
(-0.38)\end{array}$ & $\begin{array}{c}-2.373^{* *} \\
(-2.20)\end{array}$ & $\begin{array}{l}-0.129 \\
(-0.14)\end{array}$ & $\begin{array}{l}-0.655 \\
(-0.19)\end{array}$ & $\begin{array}{c}-4.143 * * \\
(-2.23)\end{array}$ & $\begin{array}{l}-0.340 \\
(-0.40)\end{array}$ & $\begin{array}{c}-2.464 * * \\
(-2.29)\end{array}$ & $\begin{array}{l}-0.171 \\
(-0.19)\end{array}$ & $\begin{array}{l}-0.670 \\
(-0.19)\end{array}$ & $\begin{array}{c}-4.193 * * \\
(-2.27)\end{array}$ \\
\hline GDP_Per_Capita $\left(\gamma_{17}\right)$ & $\begin{array}{l}-0.016 \\
(-0.87)\end{array}$ & $\begin{array}{l}-0.009 \\
(-0.35)\end{array}$ & $\begin{array}{l}0.014 \\
(0.68)\end{array}$ & $\begin{array}{l}0.002 \\
(0.05)\end{array}$ & $\begin{array}{l}-0.032 \\
(-1.12)\end{array}$ & $\begin{array}{l}-0.016 \\
(-0.87)\end{array}$ & $\begin{array}{l}-0.006 \\
(-0.24)\end{array}$ & $\begin{array}{l}0.016 \\
(0.75)\end{array}$ & $\begin{array}{l}0.006 \\
(0.13)\end{array}$ & $\begin{array}{l}-0.032 \\
(-1.09)\end{array}$ \\
\hline GDP_Per_Capita_Growth $\left(\gamma_{18}\right)$ & $\begin{array}{l}-0.002 \\
(-0.10)\end{array}$ & $\begin{array}{l}0.030 \\
(1.16)\end{array}$ & $\begin{array}{c}0.048^{*} \\
(1.85)\end{array}$ & $\begin{array}{l}-0.009 \\
(-0.24)\end{array}$ & $\begin{array}{l}0.048^{*} \\
(1.78)\end{array}$ & $\begin{array}{l}-0.002 \\
(-0.09)\end{array}$ & $\begin{array}{l}0.031 \\
(1.19)\end{array}$ & $\begin{array}{c}0.049^{*} \\
(1.87)\end{array}$ & $\begin{array}{l}-0.009 \\
(-0.24)\end{array}$ & $\begin{array}{l}0.048^{*} \\
(1.76)\end{array}$ \\
\hline Constant $\left(\gamma_{0}\right)$ & $\begin{array}{l}4.651 * * * \\
(5.64)\end{array}$ & $\begin{array}{l}9.035 * * * \\
(7.36)\end{array}$ & $\begin{array}{l}2.540 * * \\
(2.14)\end{array}$ & $\begin{array}{l}6.164 * * * \\
(2.84)\end{array}$ & $\begin{array}{l}2.001 \\
(1.33)\end{array}$ & $\begin{array}{l}4.657 * * * \\
(5.64)\end{array}$ & $\begin{array}{l}9.085^{* * *} \\
(7.52)\end{array}$ & $\begin{array}{l}2.563 * * \\
(2.23)\end{array}$ & $\begin{array}{l}6.144 * * * \\
(2.93)\end{array}$ & $\begin{array}{l}2.005 \\
(1.38)\end{array}$ \\
\hline $\begin{array}{l}\text { Number of Obs } \\
\text { R-squared }\end{array}$ & $\begin{array}{l}2,269 \\
0.506\end{array}$ & $\begin{array}{l}2,258 \\
0.611\end{array}$ & $\begin{array}{l}2,220 \\
0.534\end{array}$ & $\begin{array}{c}715 \\
0.557\end{array}$ & $\begin{array}{c}643 \\
0.656\end{array}$ & $\begin{array}{l}2,269 \\
0.506\end{array}$ & $\begin{array}{l}2,258 \\
0.614\end{array}$ & $\begin{array}{l}2,220 \\
0.535\end{array}$ & $\begin{array}{c}715 \\
0.559\end{array}$ & $\begin{array}{c}643 \\
0.658\end{array}$ \\
\hline $\begin{array}{l}\mathrm{H}_{0}: \gamma_{15}=\gamma_{\mathrm{ID}}=0 \text { (F-stat.) } \\
\mathrm{H}_{0}: \gamma_{15}+\gamma_{\mathrm{ID}}=0 \text { (F-stat.) }\end{array}$ & & & & & & $\begin{array}{c}7.67 * * \\
0.58\end{array}$ & $\begin{array}{c}71.39 * * * * \\
0.11\end{array}$ & $\begin{array}{c}86.82 * * * * \\
0.48\end{array}$ & $\begin{array}{l}3.20 \\
0.35\end{array}$ & $\begin{array}{c}18.34 * * * * \\
3.20^{*}\end{array}$ \\
\hline
\end{tabular}

Dependent Variables: Net_Interest_Margin = (Interest Income - Interest Expense) / Average Earning assets, Interest_Income_Rate $=$ Interest income divided by average earning assets for conventional banks and mark-up income over average earning assets for Islamic banks, Interest_Expense_Rate $=$ Interest expense divided by average interest bearing liabilities and profit payouts over average profit bearing liabilities for Islamic banks, Loan_Rate = Interest income on loans divided by average gross lending for conventional banks and mark-up income on lending divided by average gross loans for Islamic banks, Deposit_Rate = Interest expense on customer deposit divided by average customer deposits for conventional banks and profit payouts on customer deposits divided by average customer deposits for Islamic banks.

Explanatory Variables: Islamic_Bank $=$ Islamic bank dummy, Islamic_Window_Bank $=$ Islamic window bank dummy, Size $=$ Logarithm of total assets, Market_Share $=$ Logarithm of market share of total assets, orthogonalized on Size, Capital_Asset_Ratio $=$ The ratio of equity capital on total assets, Noninterest_Income $=$ Share of non-interest income in total operating income, Cost_Inefficiency $=$ Cost to income ratio, Loan_Loss_Reserve $=$ Loan loss reserves on gross loans ratio, State_Bank $=$ State-owned bank dummy, Foreign_Bank = Foreign-owned bank dummy, Subsidiary $=$ Subsidiary dummy, Young_Bank $=$ Young bank dummy, Middle_Aged_Bank = Middle-aged bank dummy, Domestic_Interest_Rate $=$ Domestic interest rate, Islamic_Bank $\times$ Domestic_Interest_Rate $=$ Interaction term of Islamic_Bank and Domestic_Interest_Rate, HHI $=$ HirschmanHerfindahl index, GDP_Per_Capita $=$ GDP per capita, GDP_Per_Capita_Growth $=$ Annual growth rate of GDP_Per_Capita.

In columns (1) to (5), interest rate proxies (Net_Interest_Margin, Interest_Income_Rate, Interest_Expense_Rate, Loan_Rate and Deposit_Rate) of Islamic banks are compared to those of conventional banks. In columns (6) to (10), we add the interaction term of Islamic_Bank and Domestic_Interest_Rate (Islamic_Bank $\times$ Domestic_Interest_Rate) to investigate whether interest income and expense of Islamic banks are more or less sensitive to domestic interest rate compared to conventional banks.

We apply random effect technique with robust standard errors for our estimations. All the accounting and macro level variables are lagged for one period. Year and country dummies are included in the model, but not reported in the table. Robust z-statistics are reported in parentheses. ***, ** and * indicate significance at $1 \%, 5 \%$ and $10 \%$ respectively. 